\section{Pacific Northwest}

National Laboratory

Operated by Battelle for the

U.S. Department of Energy

\title{
Iron Phosphate Glass as an Alternative Waste-Form for Hanford LAW
}

\author{
D.-S. Kim \\ M. J. Schweiger \\ W. C. Buchmiller \\ J. D. Vienna \\ Pacific Northwest National Laboratory, Richland, WA 99352 \\ D. E. Day \\ D. Zhu \\ C. W. Kim \\ University of Missouri-Rolla, Rolla, MO 65409 \\ T. E. Day \\ T. Neidt \\ MO-SCI Corporation, Rolla, MO 65402 \\ D. K. Peeler \\ T. B. Edwards \\ I. A. Reamer \\ R. J. Workman \\ Westinghouse Savannah River Company, Aiken, SC 29808
}

February 2003

Prepared for the U.S. Department of Energy

under Contract DE-AC06-76RL01830 


\title{
DISCLAIMER
}

This report was prepared as an account of work sponsored by an agency of the United States Government. Neither the United States Government nor any agency thereof, nor Battelle Memorial Institute, nor any of their employees, makes any warranty, express or implied, or assumes any legal liability or responsibility for the accuracy, completeness, or usefulness of any information, apparatus, product, or process disclosed, or represents that its use would not infringe privately owned rights. Reference herein to any specific commercial product, process, or service by trade name, trademark, manufacturer, or otherwise does not necessarily constitute or imply its endorsement, recommendation, or favoring by the United States Government or any agency thereof, or Battelle Memorial Institute. The views and opinions of authors expressed herein do not necessarily state or reflect those of the United States Government or any agency thereof.

\author{
PACIFIC NORTHWEST NATIONAL LABORATORY \\ operated by \\ BATTELLE \\ for the \\ UNITED STATES DEPARTMENT OF ENERGY \\ under Contract DE-ACO6-76RLO183O
}

This document was printed on recycled paper. 


\section{Iron Phosphate as an Alternative Waste-Form for Hanford LAW}

D.-S. Kim

W. C. Buchmiller

M. J. Schweiger

J. D. Vienna

Pacific Northwest National Laboratory, Richland, WA 99352

D. E. Day

C. W. Kim

D. Zhu

University of Missouri-Rolla, Rolla, MO 65409

T. E. Day

T. Neidt

MO-SCI Corporation, Rolla, MO 65402

D. K. Peeler

T. B. Edwards

I. A. Reamer

R. J. Workman

Westinghouse Savannab River Company, Aiken, SC 29808

February 2003

Prepared for the U.S. Department of Energy under Contract DE-AC06-76RL01830

Pacific Northwest National Laboratory

Richland, Washington 99352 


\begin{abstract}
Although the current baseline Hanford flowsheet for immobilizing low-activity waste (LAW) assumes borosilicate-based glass, opportunities exist to improve or change this baseline to reduce the current schedule and cost requirements of accomplishing the mission of site cleanup. Development of an alternative glass-forming system can lead to this goal of cost and schedule reduction through enhanced waste loading and higher plant throughput. The purpose of this project is to investigate the ironphosphate glass system as an alternative for immobilizing Hanford LAW. Previous studies on the iron phosphate glass systems and their potential advantages for immobilizing Hanford LAW have been reviewed and technical uncertainties and data required before implementing this technology have been presented. A team of researchers and engineers from the MO-SCI Corporation, the Pacific Northwest National Laboratory, the Savannah River Technology Center, and the University of Missouri at Rolla has performed a series of tests to address some of the open questions about the potential use of iron phosphate glass for immobilizing Hanford LAW. The results of this team effort are summarized along with recommendations regarding the further laboratory study needs. Additional longer-term testing requirements for implementing the iron phosphate glass-based immobilization process at Hanford are also presented.
\end{abstract}




\section{Summary}

The low-activity waste (LAW) fraction of the Hanford tank waste is an aqueous solution with a composition dominated by sodium. Past studies have determined that the loading of LAW in the baseline borosilicate glass will be determined by the allowable concentrations of $\mathrm{Na}_{2} \mathrm{O}$ and $\mathrm{SO}_{3}$ in glass. Sulfate salt segregation is the determining factor that limits the $\mathrm{SO}_{3}$ concentration that can be in glass. The current baseline estimate of LAW glass to be produced is 650938 metric tons (MT) if it is assumed that

- all LAW is vitrified in borosilicate glass,

- a total of $74615 \mathrm{MT}$ of $\mathrm{Na}_{2} \mathrm{O}$ and $3166 \mathrm{MT}$ of $\mathrm{SO}_{3}$ is in $\mathrm{LAW}$, and

- waste loading is determined by the rule-of-five (the product of mass\%'s of $\mathrm{Na}_{2} \mathrm{O}$ and $\mathrm{SO}_{3}$ in glass should be 5 or smaller) and a limit of 20 mass $\% \mathrm{Na}_{2} \mathrm{O}$ in glass.

However, it has been shown that sulfate salt segregation may not occur with phosphate-based glasses. If a phosphate glass that can accommodate up to 20 mass $\% \mathrm{Na}_{2} \mathrm{O}$ is used, then only $373075 \mathrm{MT}$ of glass would be produced from all of Hanford LAW. This represents a $43 \%$ reduction in glass mass from the baseline.

The potential increase in waste loading that could be achieved by using a phosphate-based glass may defer the cost of having to invest in additional capacity and/or avoid significant increases in WTP operating costs. Another possible application of iron phosphate glass would be to selectively immobilize the waste streams with high sulfur contents in addition to the current borosilicate baseline for non-sulfur limited wastes.

This study investigates the iron-phosphate glass system as an alternative for immobilizing Hanford LAW. As part of this project, the team consisting of researchers and engineers from the MO-SCI Corporation, the Pacific Northwest National Laboratory (PNNL), the Savannah River Technology Center (SRTC), and the University of Missouri at Rolla (UMR) has performed a series of tests to address some of the open questions about the potential use of iron phosphate glass for immobilizing Hanford LAW.

From the limited experimental studies and review of the past research efforts on the phosphate-based glasses performed in this study, it was concluded that phosphate glasses containing over 20 mass $\% \mathrm{Na}_{2} \mathrm{O}$ have a satisfactory chemical durability showing only a minor decrease of chemical durability after partial crystallization upon slow cooling and that the phosphate-based glasses show no indication of sulfate segregation during laboratory melting tests, which implies that the waste loading in the iron phosphate glasses will not be limited by the $\mathrm{SO}_{3}$ content of the waste. It was also shown that it would be possible to achieve high sulfate retention through glass formulation.

Based on the promising results obtained for the LAW-containing iron phosphate waste forms investigated in the present work, recommended areas for further study include: 1) optimization of glass composition especially in terms of sulfate retention and melting rate, 2) selection of refractory and electrode materials for optimum service performance, 3) expanded durability testing, and 4) partitioning and release of radioactive components in partly crystallized glasses. Additional long-term needs that should be addressed before implementing iron phosphate glass in LAW immobilization efforts include 1) defining the qualified glass composition region for product qualification based on the glass propertycomposition models, 2) design data development to provide the technical basis for plant design such as partitioning of sulfur in glass and off-gas, and 3) the development/demonstration of processing the Hanford LAW using a phosphate-based glass with a fully integrated flowsheet. 


\section{Glossary}

\begin{tabular}{|c|c|}
\hline ARM & Approved Reference Material (ARM-1) \\
\hline ASTM & American Society for Testing and Materials \\
\hline BOM & balance of mission \\
\hline $\mathrm{CCC}$ & centerline canister cooling \\
\hline CCIM & cold-wall crucible induction melter \\
\hline CSM & centimeter scale melter \\
\hline DIW & deionized water \\
\hline DOE & U.S. Department of Energy \\
\hline DR & dissolution rate \\
\hline DTA & differential thermal analysis \\
\hline DWPF & Defense Waste Processing Facility \\
\hline EA & environmental assessment \\
\hline ED & electron diffraction \\
\hline EDS & energy dispersive spectroscopy \\
\hline EDTA & ethylenediaminetetraacetic acid \\
\hline EMSP & Environmental Management Science Program \\
\hline GFA & glass-forming additive \\
\hline HLW & high-level waste \\
\hline HTWOS & Hanford Tank Waste Optimization Simulator \\
\hline IA & image analysis \\
\hline IC & ion chromatography \\
\hline ICP-AES & inductively coupled plasma-atomic emission spectroscopy \\
\hline ICP-OES & inductively coupled plasma-optical emission spectrometry \\
\hline ILAW & immobilized low-activity waste \\
\hline INEEL & Idaho National Engineering and Environmental Laboratory \\
\hline JHCM & Joule-heated, ceramic-lined melter \\
\hline LAW & low-activity waste \\
\hline
\end{tabular}




\begin{tabular}{|c|c|}
\hline MT & metric ton \\
\hline $\mathrm{OM}$ & optical microscopy \\
\hline ORP & Office of River Protection \\
\hline PCT & Product Consistency Test \\
\hline PNNL & Pacific Northwest National Laboratory \\
\hline RPP & River Protection Program \\
\hline SBW & sodium-bearing waste \\
\hline SEM & scanning electron microscopy \\
\hline SRTC & Savannah River Technology Center \\
\hline $\mathrm{T}$ & temperature \\
\hline TCLP & Toxicity Characteristic Leach Procedure \\
\hline TEC & thermal-expansion coefficient \\
\hline TEM & transmission electron microscopy \\
\hline TFCOUP & Tank Farm Contractor's Operation and Utility Plan \\
\hline $\mathrm{T}_{\mathrm{g}}$ & glass transition temperature \\
\hline$T_{L}$ & liquidus temperature \\
\hline UMR & University of Missouri-Rolla \\
\hline VHT & vapor hydration test \\
\hline$\eta$ & viscosity \\
\hline WSRC & Westinghouse Savannah River Company \\
\hline WTP & Waste Treatment Plant \\
\hline XRD & X-ray diffraction \\
\hline XRF & $\mathrm{X}$-ray fluorescence \\
\hline
\end{tabular}




\section{Acknowledgments}

The authors would like to acknowledge Pat Toole, Daniel Pittman, and Sherry Vissage for chemical analyses; Wayne Cosby for masterful and prompt editing; and William Holtzscheiter for management and guidance. This study was partially funded by the Department of Energy Office of Science and Technology through the Tanks Focus Area. Pacific Northwest National Laboratory is operated by Battelle for the U.S. Department of Energy under Contract DE-AC06-76RLO 1830. 


\section{Contents}

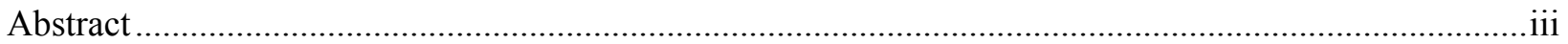

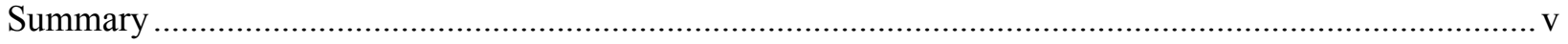

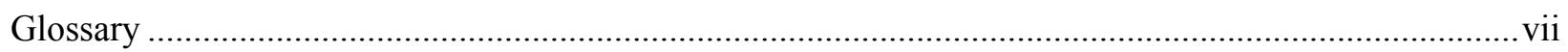

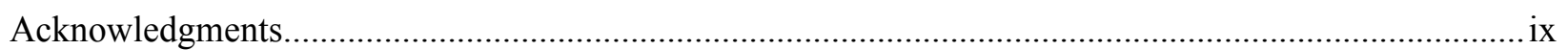

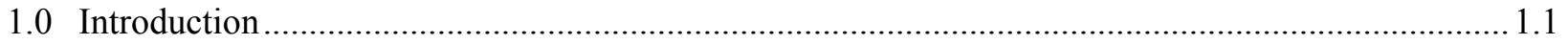

2.0 Potential Advantages of the Iron Phosphate Glass Systems to Hanford LAW ..............................2.1

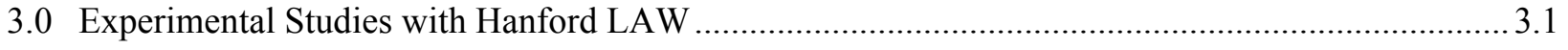

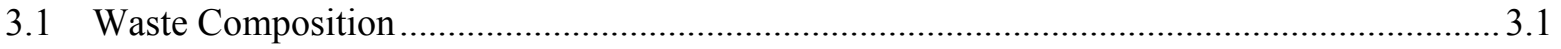

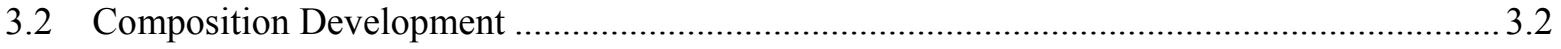

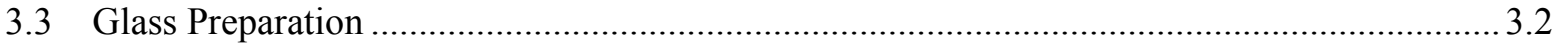

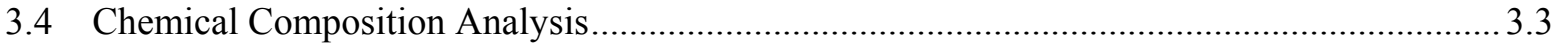

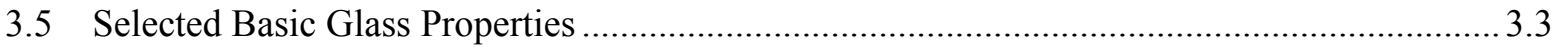

3.6 Crystallinity by X-Ray Diffraction (XRD) and Scanning Electron Microscopy (SEM) ...........3.4

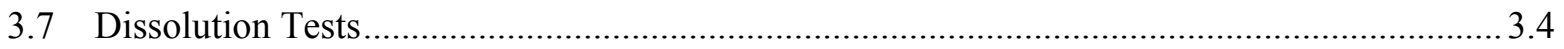

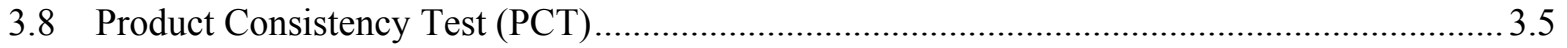

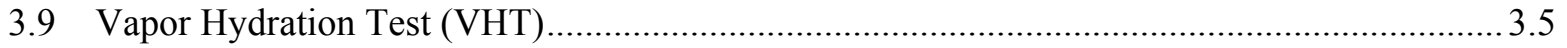

3.10 Centimeter Scale Melter (CSM) Tests with Simulated LAW Feed ........................................... 3.6

3.11 One-Component-at-a-Time Variation Study.................................................................. 3.9

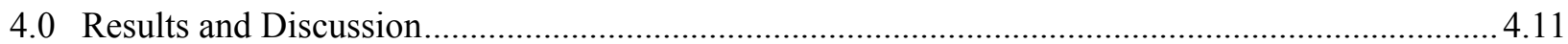

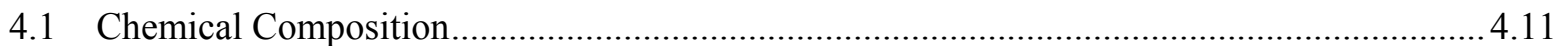

4.2 Selected Basic Glass Properties ........................................................................................ 4.11

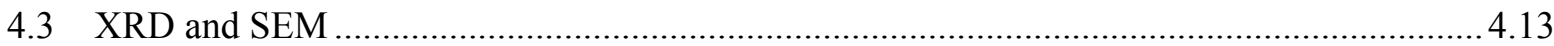

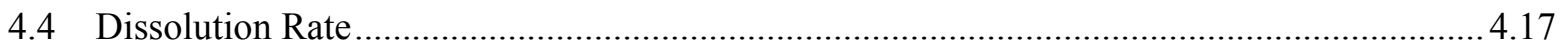

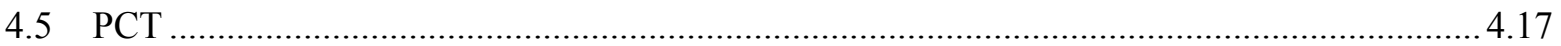

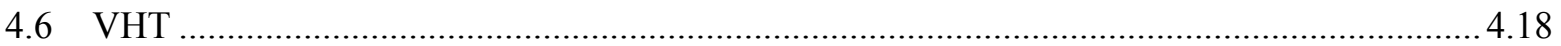

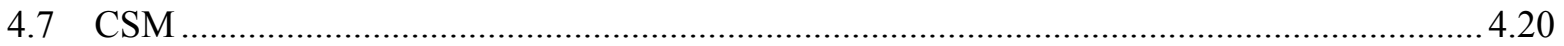

4.8 Results of One-Component-at-a-Time Variation Study ...................................................... 4.20

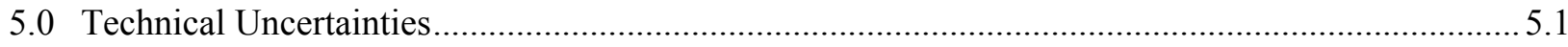

5.1 Impact of Crystallization on Durability …....................................................................... 5.1 


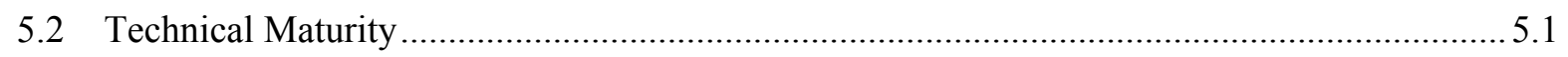

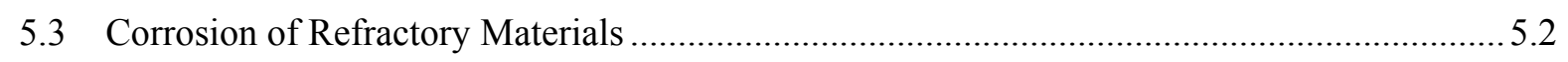

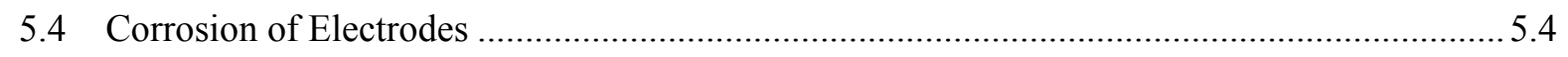

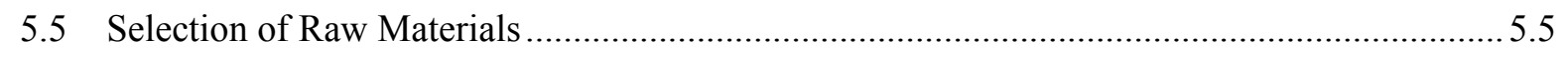

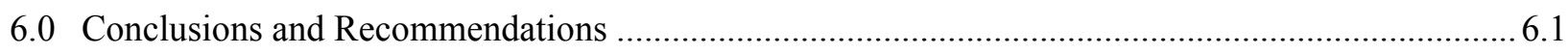

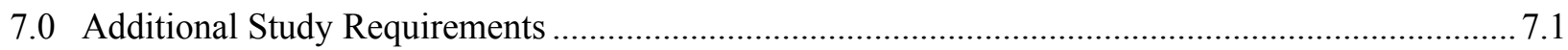

7.1 Qualified Glass Composition Region ................................................................................... 7.1

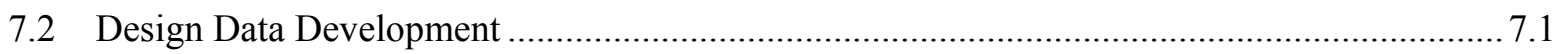

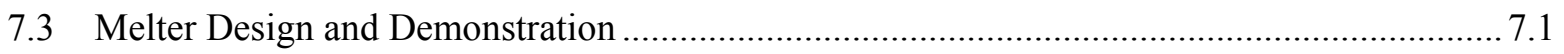

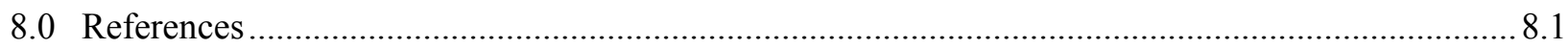

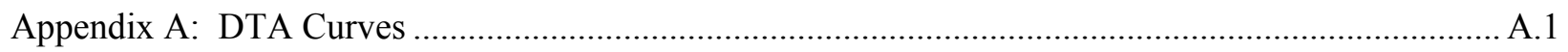

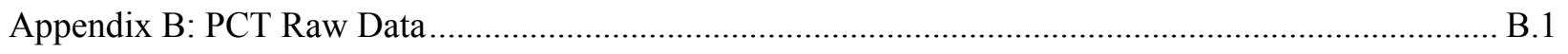




\section{Figures}

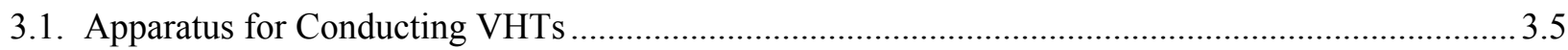

3.2. Schematic Diagram of the Centimeter-Scale Melter (CSM) ........................................................ 3.8

4.1. A) The Change in Viscosity with Temperature and B) Logarithm of Viscosity Versus

1/T Plot for MS-LAW-1-1 Melt Compared to Other Iron Phosphate Glasses (IP70W:

I-P glass containing 70 mass $\%$ high chrome waste at Hanford (Huang et al. 2003); F40:

$\left.40 \mathrm{Fe}_{2} \mathrm{O}_{3} 60 \mathrm{P}_{2} \mathrm{O}_{5}, \mathrm{~mol} \%\right)$

4.2. AC Electrical Conductivity of MS-LAW-1-1 Compared to SBW-22-20 (Vienna et al. 2002a) .....4.13

4.3. MS-LAW-1 Annealed Glass.

4.4. MS-LAW-1 CCC Treated Glass

4.5. MS-LAW-1-1 Quenched Glass

4.6. MS-LAW-1-1 Annealed Glass

4.7. MS-LAW-1-1 CCC Treated Glass.

4.8. MS-LAW-1-2 Quenched Glass

4.9. MS-LAW-1-2 Annealed Glass

4.10.MS-LAW-1-2 CCC Treated Glass.

4.11.Optical micrograph of the Cross Section of Glassy and Deliberately Crystallized (CCC) Iron Phosphate Waste Forms (27 wt\% LAW) after VHT at $200^{\circ} \mathrm{C}$ for 7 Days....

4.12. Comparison of $\mathrm{SO}_{3}$ Concentrations Obtained by XRF and ICP-AES 4.22

4.13.Effect of Component Concentration Change on the $\mathrm{SO}_{3}$ Retention

4.14.Effect of $[\mathrm{O}] /[\mathrm{P}]$ Ratio in the Glasses for One-Component-at-a-Time Variation Study on the $\mathrm{SO}_{3}$ Retention

5.1. A Cross Section of a DFC Crucible in Which the MS-LAW-1 Composition Was Melted for $3 \mathrm{~h}$ at $1250^{\circ} \mathrm{C}$ and then Cooled for $48-\mathrm{hr}$ for the CCC Heat Treatment.

5.2. Weight Loss of Inconel 690 and 693 Samples Totally Submerged in Iron Phosphate Melt (22 mass\% soda) containing 30 mass $\%$ of Hanford LAW Waste 


\section{Tables}

1.1. Summary of Composition of Hanford LAW Feed (mass\% non-volatile oxides and halogens) ........ 1.2

3.1. Composition of LAW Feed Used in Experimental Studies (mass \% non-volatile oxides

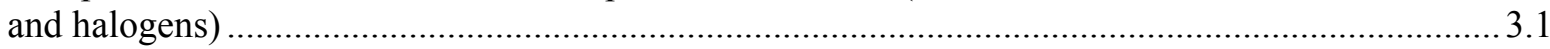

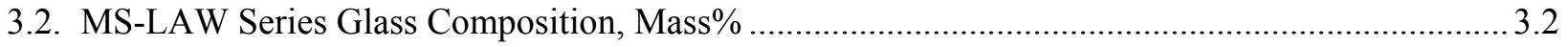

3.3. Temperature Profile Line Segments Used as Guidelines for Programming the Furnace Controller to Generate the Canister Centerline Cooling Profile ........................................................ 3.3

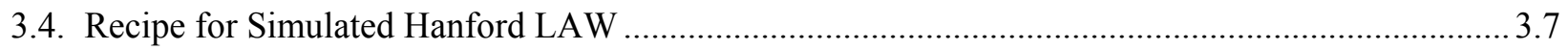

3.5. Glass-Forming Chemicals Per Liter of LAW Slurry to Produce the MS-LAW-1 Glass at 27

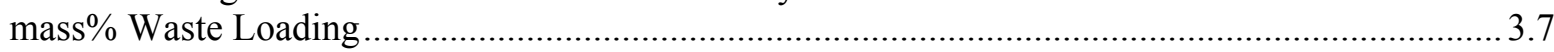

3.6. Formulation of Base Glass and Component Variation in One-Component Study Test Matrix....... 3.10

4.1. Target Composition and Measured Composition for the MS-LAW-1 Glass ................................4.11

4.2. Density, Thermal-Expansion Coefficient (TEC) and Liquidus Temperature $\left(\mathrm{T}_{\mathrm{L}}\right)$ of Iron Phosphate Waste Glasses.....

4.3. High Temperature Viscosity and AC Electrical Conductivity for MS-LAW-1-1 Melt

4.4. Summary of Crystalline Phases Identified by XRD ....................................................................... 4.16

4.5. Dissolution Rates of Annealed Iron Phosphate Glasses in DIW at $90^{\circ} \mathrm{C}$.................................... 4.17

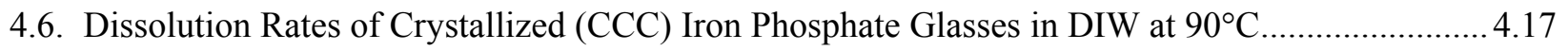

4.7. Summary of Normalized Elemental Release for the MS-LAW-1 Glass ...................................... 4.18

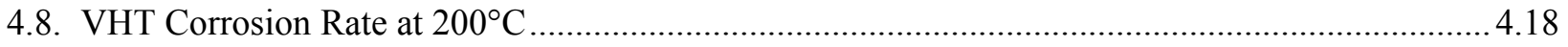

4.9. Target and Analyzed Compositions of Phosphate Glasses for One-Component Study and Melting Temperature Used to Melt the Glasses.....

5.1. Information on DFC Ceramics Crucible (supplied by DFC) ..........................................................

5.2. MS-LAW-1-1 Glass Forming Additives Composition ..................................................................... 5.6 


\subsection{Introduction}

The Hanford Site's mission was to produce nuclear materials for the U.S. Department of Energy (DOE) and its predecessors. A large inventory (approximately 200,000 $\mathrm{m}^{3}$ ) of high-level wastes (HLW) generated from roughly 4 decades of nuclear fuel processing and actinide separations is being stored in 177 underground single- and double-shell tanks. These wastes are to be retrieved and immobilized as part of the River Protection Program (RPP) being operated by the DOE Office of River Protection (ORP).

DOE is proceeding with construction of a waste treatment plant (WTP) that will receive waste from tank-farm operations, separate liquid and solid waste, wash and/or leach the solids, separate key radionuclides from the liquid, and vitrify both streams separately. In the most recent WTP design, two Joule-heated ceramic melters (JHCMs), each operating at $3 \mathrm{MT} / \mathrm{d}$, will immobilize the HLW fraction and two JHCMs, each operating at $15 \mathrm{MT} / \mathrm{d}$, will immobilize the low-activity waste (LAW) fraction.

The baseline Hanford flowsheet assumes borosilicate-based glass for both HLW and LAW. Even though this glass-forming system has general national and international acceptance, opportunities may exist to improve or change this baseline to reduce the enormous cost of accomplishing the mission of site cleanup. Thereby, identifying alternative glass-forming systems and/or melter technologies may yield enhanced waste loadings and higher melting rates, both potentially leading to higher waste throughput. The focus of this report is on the iron-phosphate glass system as an alternative for immobilizing Hanford LAW.

The LAW fraction of the Hanford tank waste is an aqueous solution with a composition dominated by sodium. The oxide composition of the non-volatile portion of the waste stream is summarized in Table 1.1. Past studies have determined that the loading of LAW in the baseline borosilicate glass will be determined by the allowable concentrations of $\mathrm{Na}_{2} \mathrm{O}$ and $\mathrm{SO}_{3}$ in glass (Muller et al. 2001). The current WTP technical baseline has defined the waste loading for LAW in glass given by the rule-of-five or (Muller et al. 2001):

$$
M_{\mathrm{Na}_{2} \mathrm{O}} \times M_{\mathrm{SO}_{3}} \leq 5
$$

where $M_{\mathrm{Na} 2 \mathrm{O}}$ and $M_{\mathrm{SO} 3}$ are the mass $\%$ of $\mathrm{Na}_{2} \mathrm{O}$ and $\mathrm{SO}_{3}$ in the target glass composition, respectively. According to the Tank Farm Contractor's Operation and Utility Plan (TFCOUP, Kirkbride 2000), the LAW will be sent to the melter in roughly 900 batches with a total of 74615 metric tons (MT) of $\mathrm{Na}_{2} \mathrm{O}$ and $3166 \mathrm{MT}$ of $\mathrm{SO}_{3}$. As loading is determined by a non-linear function of $\mathrm{Na}_{2} \mathrm{O}$ and $\mathrm{SO}_{3}$ masses, the loading for each of the 900 batches was calculated separately. For the waste batches with low sulfur, a limit of 20 mass $\% \mathrm{Na}_{2} \mathrm{O}$ in glass was used. The results suggest that $650938 \mathrm{MT}$ of glass will be produced at WTP if all LAW is vitrified in borosilicate glass. It should be noted that it may be possible to process LAW waste with up to 20 mass $\% \mathrm{Na}_{2} \mathrm{O}$ and 0.8 mass $\% \mathrm{SO}_{3}$ as shown by Vienna et al. (2002a). If 20 mass $\% \mathrm{Na}_{2} \mathrm{O}$ and 0.8 mass $\% \mathrm{SO}_{3}$ are defined as the independent waste-loading limits, then 494436 MT of glass would be produced at WTP. However, development work would be required to achieve this level of waste loading in borosilicate glasses. It was shown that sulfate salt segregation may not occur with phosphate-based glasses, assuming a targeted $\mathrm{Na}_{2} \mathrm{O}$ concentration of 20 mass $\%$. More specifically, if a phosphate glass that can accommodate up to 20 mass $\% \mathrm{Na}_{2} \mathrm{O}$ is used, then only $373075 \mathrm{MT}$ of glass would be produced from all of Hanford LAW. This represents a $43 \%$ reduction in glass mass from the baseline. 
Table 1.1. Summary of Composition of Hanford LAW Feed (mass\% non-volatile oxides and halogens)

\begin{tabular}{||l|c|c|r||}
\hline Oxide & Min & Ave & Max \\
\hline $\mathrm{Al}_{2} \mathrm{O}_{3}$ & 0.68 & 13.19 & 35.62 \\
\hline $\mathrm{Cl}$ & 0.00 & 0.89 & 2.61 \\
\hline $\mathrm{Cr}_{2} \mathrm{O}_{3}$ & 0.00 & 0.33 & 1.64 \\
\hline $\mathrm{F}$ & 0.00 & 0.94 & 5.38 \\
\hline $\mathrm{K}_{2} \mathrm{O}$ & 0.00 & 1.02 & 16.06 \\
\hline $\mathrm{MoO}_{3}$ & 0.00 & 0.01 & 5.06 \\
\hline $\mathrm{Na}_{2} \mathrm{O}$ & 32.24 & 75.25 & 97.93 \\
\hline $\mathrm{P}_{2} \mathrm{O}_{5}$ & 0.29 & 4.08 & 48.72 \\
\hline $\mathrm{SiO}_{2}$ & 0.01 & 0.86 & 7.42 \\
\hline $\mathrm{SO}_{3}$ & 0.02 & 3.19 & 14.11 \\
\hline $\mathrm{Other}$ & 0.01 & 0.23 & 1.61 \\
\hline \hline
\end{tabular}

The potential increase in waste loading that could be achieved by using a phosphate-based glass may defer the cost of having to invest in additional capacity and/or avoid significant increases in WTP operating costs. ${ }^{(a)}$ Although estimating the cost and schedule benefits that can be achieved by reducing the glass mass by $43 \%$ are beyond the scope of this investigation, it is thought to be a significant impact. Another possible application of iron phosphate glass would be to selectively immobilize the waste streams with high sulfur contents in addition to the current borosilicate baseline for non-sulfur limited systems.

Previous studies on the iron phosphate glass systems and their potential advantages for immobilizing Hanford LAW are summarized in Section 2.0. As part of this project, the team consisting of researchers and engineers from the MO-SCI Corporation, the Pacific Northwest National Laboratory (PNNL), the Savannah River Technology Center (SRTC), and the University of Missouri at Rolla (UMR) has performed a series of tests to address some of the open questions about the potential use of iron phosphate glass for immobilizing Hanford LAW. Sections 3.0 and 4.0 provide a description of these studies and their results and discussion. Although an impressive body of past research and testing shows promise for the use of iron phosphate glass, there are a number of technical uncertainties and data needs that must be investigated before implementing this technology. These technical uncertainties and data needs are discussed in Section 5.0. The results of this project are summarized in Section 6.0 along with recommendations regarding the additional laboratory study needs. Additional longer-term testing requirements for implementing the iron phosphate glass-based immobilization process at Hanford are described in Section 7.0.

(a) The Office of River Protection (ORP) baseline life-cycle cost currently assumes $20 \% \mathrm{Na}_{2} \mathrm{O}$ loading for tank waste immobilized during the Balance of Mission (BOM), not the rule-of-five. 


\subsection{Potential Advantages of the Iron Phosphate Glass Systems to Hanford LAW}

Most of the basic research on iron phosphate glasses in the United States has been conducted at the UMR, where work on applying these chemically durable glasses to vitrify nuclear waste started about 10 years ago. The research at UMR, which still continues, has been supported by the DOE Environmental Management Science Program (EMSP) since 1996. A chronological list of papers published at UMR during the past decade is included in Section 8.0. As the unique properties of iron phosphate glasses have become better known, interest in these glasses has expanded to the point that they are now being investigated by groups working in waste vitrification in Great Britain, Japan, where they are being studied for vitrifying the waste from reprocessed nuclear fuel, and Brazil. In Russia, similar glass compositions have been used to immobilize HLW waste for more than 10 years. More recently, attention at PNNL has been given to the study of phosphate glass as a waste form for vitrifying wastes with high sulfur content (Kim et al. 2003c).

Perhaps the most important point to understand about iron phosphate glasses is that they are quite different in their properties and behavior from conventional phosphate glasses, and their properties are more like silicate glasses than phosphate glasses (Marasinghe et al. 2000 and 2001). Iron phosphate glasses have unique and unexpected properties, and it is a mistake to apply our knowledge for other types of phosphate glasses to iron phosphate glasses.

There are several reasons why iron phosphate glasses are of interest in the field of waste vitrification, but certainly two of the most important are 1) their exceptionally good chemical durability, even when they contain large amounts of alkali oxides and 2) their compatibility with wastes that contain components such as heavy metals (e.g., Bi, Cr, Zr, Mo, and Ag), phosphate, halides (F), and sulfates that are poorly suited (soluble) for borosilicate glasses and may reduce the waste loading to unacceptably low levels. For wastes with significant concentrations of these "problematic" components (e.g., Hanford LAW with high $\mathrm{SO}_{3}$ content), iron phosphate glasses of equal (or higher) chemical durability may offer an alternative to borosilicate glasses such that higher waste loadings can be achieved (smaller final volume of waste form) at a significant cost savings.

Hanford LAW loading in iron phosphate glasses may be limited solely by the overall $\mathrm{Na}_{2} \mathrm{O}$ content as opposed to the sulfate content or a combination of $\mathrm{Na}_{2} \mathrm{O}$ and $\mathrm{SO}_{3}$. If true, the potential increase in LAW loading that could be achieved by using a phosphate-based glass may defer the cost of having to invest in additional capacity and/or avoid significant increases in WTP operating costs. 


\subsection{Experimental Studies with Hanford LAW}

A limited experimental program was implemented to provide insight into the potential application of iron phosphate glasses for immobilizing Hanford LAW as well as to address some of the technical uncertainties previously identified in the review of phosphate glass for HLW vitrification (Perez et al. 2001). Key product and process acceptance properties were evaluated for various glass compositions produced using a specific LAW waste stream.

This section describes waste composition used in this study, preliminary composition development, and experimental approaches and procedures to evaluate the properties related to the vitrification of Hanford LAW.

\subsection{Waste Composition}

The waste volumes and compositions estimated with the Hanford Tank Waste Optimization Simulator (HTWOS) for the Tank Farm Contractors Operation and Utilization Plan (TFCOUP) (Kirkbride 2001) were used as the basis of LAW compositions used in this study. The HTWOS estimation resulted in $\sim 900$ batches of LAW. The LAW batches were sorted by $\mathrm{SO}_{3}$ concentration (on a dry non-volatile oxide mass $\%$ basis), and those with $\mathrm{SO}_{3}$ concentrations above 7 mass $\%$ were selected as candidate compositions for testing with iron-phosphate glasses. The mass-weighted average composition of these high-sulfur Hanford LAW batches, given in Table 3.1, was used as the LAW composition for the present study.

Table 3.1. Composition of LAW Feed Used in Experimental Studies (mass\% non-volatile oxides and halogens)

\begin{tabular}{|c|c|}
\hline Component & $\operatorname{mass} \%$ \\
\hline $\mathrm{Al}_{2} \mathrm{O}_{3}$ & 4.39 \\
\hline $\mathrm{Bi}_{2} \mathrm{O}_{3}$ & 0.02 \\
\hline $\mathrm{CaO}$ & 0.09 \\
\hline $\mathrm{Cl}$ & 0.59 \\
\hline $\mathrm{Cr}_{2} \mathrm{O}_{3}$ & 0.29 \\
\hline $\mathrm{F}$ & 1.59 \\
\hline $\mathrm{Fe}_{2} \mathrm{O}_{3}$ & 0.08 \\
\hline $\mathrm{K}_{2} \mathrm{O}$ & 0.49 \\
\hline $\mathrm{Na}_{2} \mathrm{O}$ & 74.80 \\
\hline $\mathrm{NiO}$ & 0.01 \\
\hline $\mathrm{P}_{2} \mathrm{O}_{5}$ & 7.68 \\
\hline $\mathrm{SiO}_{2}$ & 0.53 \\
\hline $\mathrm{SO}_{3}$ & 9.41 \\
\hline Others $^{(a)}$ & 0.04 \\
\hline Total & 100.00 \\
\hline \multicolumn{2}{|c|}{$\begin{array}{l}\text { (a) Sum of concentrations for components } \\
\text { with }<0.01 \mathrm{mass} \%\end{array}$} \\
\hline
\end{tabular}




\subsection{Composition Development}

Table 3.2 lists the series of four compositions developed and tested in this study. The waste composition in Table 3.2 represents a simplified version of the waste given in Table 3.1. One of the goals was to have an iron phosphate glass that contained at least 20 mass $\% \mathrm{Na}_{2} \mathrm{O}$ while maintaining acceptable process and product performance properties. All compositions investigated contained 20.3 mass $\% \mathrm{Na}_{2} \mathrm{O}$ (waste loading of $27 \mathrm{mass} \%$ ) in the final iron phosphate glass waste form. The simplified version (MSLAW-1 Simplified) merely omitted some glass-forming additive (GFA) constituents and increased the $\mathrm{Fe}_{2} \mathrm{O}_{3}$. MS-LAW-1-1 decreased the total amount of CaO from MS-LAW-1. MS-LAW-1-2 used AlF $\mathrm{As}_{3}$ as the source of fluorine in place of $\mathrm{CaF}_{2}$. It should be noted that $\mathrm{Bi}_{2} \mathrm{O}_{3}$ and $\mathrm{CaO}$ were ultimately added as GFAs, so their omission from the waste and the resulting impact on measured properties is not an issue. Only $\mathrm{NiO}$ and $\mathrm{K}_{2} \mathrm{O}$ were not included in these glass compositions and given their anticipated concentration in glass; their omission is not of concern regarding measured properties.

Table 3.2. MS-LAW Series Glass Composition, Mass\%

\begin{tabular}{|c|c|c|c|c|c|c|c|}
\hline $\begin{array}{l}\text { Oxide } \\
(\text { wt\%) }\end{array}$ & $\begin{array}{c}\text { Hanford } \\
\text { LAW }\end{array}$ & $\begin{array}{l}27 \mathrm{wt} \% \\
\text { LAW }\end{array}$ & $\begin{array}{c}73 \text { wt } \% \\
\text { GFA for } \\
\text { MS-LAW-1 }\end{array}$ & MS-LAW-1 & $\begin{array}{c}\text { MS-LAW-1 } \\
\text { Simplified }\end{array}$ & MS-LAW-1-1 & MS-LAW-1-2 \\
\hline $\mathrm{Al}_{2} \mathrm{O}_{3}$ & 4.4 & 1.2 & 14.6 & 15.8 & \begin{tabular}{|l|}
15.8 \\
\end{tabular} & 16.1 & \begin{tabular}{|l|}
14.8 \\
\end{tabular} \\
\hline $\mathrm{Cl}$ & 0.6 & 0.2 & 0.0 & 0.2 & 0.2 & 0.2 & 0.2 \\
\hline $\mathrm{Cr}_{2} \mathrm{O}_{3}$ & 0.4 & 0.1 & 2.9 & 3.0 & 3 & 3.4 & 3.4 \\
\hline $\mathrm{F}$ & 1.6 & 0.4 & 0.6 & 1.0 & 2.6 & 1.1 & 2.3 \\
\hline $\mathrm{Na}_{2} \mathrm{O}$ & 75.3 & 20.3 & 0.0 & 20.3 & 20.2 & 20.2 & 20.3 \\
\hline $\mathrm{P}_{2} \mathrm{O}_{5}$ & 7.7 & 2.1 & 26.7 & 28.8 & 28.6 & 29 & 30.0 \\
\hline $\mathrm{SiO}_{2}$ & 0.5 & 0.1 & 11.9 & 12.0 & 12 & 12.4 & 12.7 \\
\hline $\mathrm{SO}_{3}$ & 9.5 & 2.6 & 0.0 & 2.6 & 2.6 & 2.6 & 2.6 \\
\hline $\mathrm{Bi}_{2} \mathrm{O}_{3}$ & & & 2.3 & 2.3 & & 2.7 & 2.7 \\
\hline $\mathrm{Fe}_{2} \mathrm{O}_{3}$ & & & 6.8 & 6.8 & 12.2 & 7.2 & 6.9 \\
\hline $\mathrm{La}_{2} \mathrm{O}_{3}$ & & & 0.8 & 0.8 & & 1.2 & 1.3 \\
\hline $\mathrm{ZrO}_{2}$ & & & 2.3 & 2.3 & & 2.7 & 2.8 \\
\hline $\mathrm{CaO}$ & & & 4.1 & 4.1 & 2.8 & 1.2 & \\
\hline Total & 100.0 & 27.0 & 73.0 & 100.0 & 100.0 & 100.0 & 100.0 \\
\hline
\end{tabular}

\subsection{Glass Preparation}

The raw materials used in the preparation of the glasses were reagent-grade chemicals. Each component was weighed and placed in a polyethylene bag. After adding all raw materials, the bag was sealed and agitated for sufficient time to completely mix the components. All glasses were melted in electric $(\mathrm{SiC})$ furnaces in air at $1250^{\circ} \mathrm{C}$ for 3 hours in dense fused high-silica (DFC $83 \%$ silica $17 \%$ alumina) crucibles. Each melt was stirred 3 to 4 times with a fused silica rod to assure chemical homogeneity and consistency. After 3 hours at $1250^{\circ} \mathrm{C}$, the crucibles were removed from the furnace, and the glass was cast into bars and annealed. All glass bar and patty samples were annealed at $520 \pm 5^{\circ} \mathrm{C}$ in a fully programmable annealing oven for 5 hours and cooled to room temperature overnight in the oven. The annealing temperature was determined from differential thermal analysis (DTA) measurements.

A sample of each MS-LAW compositional series was also cooled according to the simulated immobilized low-activity waste (ILAW) centerline canister cooling (CCC) profile as given in Table 3.3 
(Smith et al. 2000). The as-prepared/annealed samples will be referred to as "annealed" glasses throughout this report as opposed to CCC treated or quenched (no annealing) glasses.

Table 3.3. Temperature Profile Line Segments Used as Guidelines for Programming the Furnace Controller to Generate the Canister Centerline Cooling Profile

\begin{tabular}{||c|c|c||}
\hline Hours & Temperature $\left({ }^{\mathbf{}} \mathbf{C}\right)$ & $\Delta \mathbf{T} / \Delta \mathbf{t}(\mathbf{d e g} / \mathbf{h r})$ \\
\hline $0.06-0.6$ & $1021-1001$ & -37.60 \\
\hline $0.6-1.8$ & $1001-977$ & -20.01 \\
\hline $1.8-2.8$ & $977-970$ & -7.26 \\
\hline $2.8-9.0$ & $970-964$ & -0.89 \\
\hline $9.0-16.0$ & $964-910$ & -7.78 \\
\hline $16.0-24.0$ & $910-781$ & -16.14 \\
\hline $24.0-38.0$ & $781-536$ & -17.46 \\
\hline $38.0-48.6$ & $536-397$ & -13.16 \\
\hline
\end{tabular}

The four glasses presented in Table 3.2 were developed in a chronological manner. Given programmatic constraints, properties for each glass were not measured for each of the four glasses. Obtaining properties for the MS-LAW-1 glass was the initial primary focus, and as results were obtained, minor compositional adjustments to the GFAs were made. Samples of the MS-LAW-1 composition (both annealed and partially crystallized samples) were prepared at MO-SCI and sent to PNNL and SRTC for testing.

\subsection{Chemical Composition Analysis}

To confirm that the as-fabricated glass corresponds to the defined target composition, a representative sample of MS-LAW-1 glass pour patty was chemically analyzed. (A chemical-analysis sample was submitted before selecting MS-LAW-1-1.) Cation concentrations were measured by inductively coupled plasma-atomic emission spectroscopy (ICP-AES). ${ }^{(a)}$ Anion analyses $(\mathrm{F}$ and $\mathrm{Cl})$ were performed by ion chromatography (IC). ${ }^{(b)}$

\subsection{Selected Basic Glass Properties}

Selected basic glass properties were measured for selected MS-LAW glasses: the thermal-expansion coefficient (TEC) and glass-transition temperature $\left(\mathrm{T}_{\mathrm{g}}\right)$ were determined by dilatometer and DTA, respectively; the room-temperature density for annealed and CCC treated glasses was measured by the Archimedes' method using deionized water; the liquidus temperature $\left(\mathrm{T}_{\mathrm{L}}\right)$ was measured per ASTM C 829-81 procedures in a temperature gradient furnace using a platinum tray in which glass particles were fused to form a thin $(\sim 3 \mathrm{~mm})$ layer of melt, and the platinum tray holding the melt remained in the furnace for $24 \mathrm{~h}$ to ensure that equilibrium between the crystal and glassy phases was established; DTA was performed in flowing nitrogen at a heating rate of $10^{\circ} \mathrm{C} / \mathrm{min}$ from 30 to 850 or $1000^{\circ} \mathrm{C}$.

The viscosity of the MS-LAW-1-1 melt over its melting range was measured using a Brookfield rotating viscometer modified for high-temperature use. Three standard viscosity oils (97.2, 98.8, and 965 centipoise) were used to calibrate the viscometer. Repeated measurements indicated that the estimated

(a) Two dissolutions were performed to support ICP-AES analysis. A sodium peroxide fusion technique was used from which elemental concentrations of $\mathrm{Al}, \mathrm{Bi}, \mathrm{Ca}, \mathrm{Cr}, \mathrm{Fe}$, and $\mathrm{Si}$ were obtained. A lithium-metaborate fusion was used from which elemental concentrations of $\mathrm{La}, \mathrm{Na}, \mathrm{P}, \mathrm{S}$, and $\mathrm{Zr}$ were obtained.

(b) A potassium hydroxide fusion with $\mathrm{H}_{2} \mathrm{O}$ uptake was used to support $\mathrm{IC}$ analysis of $\mathrm{Cl}$ and $\mathrm{F}$. 
error was $< \pm 5 \%$. The melt was thermally equilibrated at a selected temperature for 30 to $60 \mathrm{~min}$, whereupon, the preheated spindle (located just above the melt) was immersed in the melt. Spindle speeds of 10 and $20 \mathrm{rpm}$ were used for each measurement. The viscosity of the melt was measured three times (at each temperature and spindle rpm) and then averaged.

The AC electrical conductivity of the MS-LAW-1-1 glass was measured between 900 and $1350^{\circ} \mathrm{C}$ at $1 \mathrm{kHz}$. Two parallel Pt $/ 10 \% \mathrm{Rh}$ electrodes were immersed in the melt, and the dimension of the immersed part of the electrodes was $1 \mathrm{~cm} \times 2 \mathrm{~cm}$. The distance between the two electrodes was $1.5 \mathrm{~cm}$. The resistance between the two electrodes in the melt was measured directly by a LCR (Inductance $[L]$, capacitance $[C]$, and resistance $[R]$ ) meter, and the resistance was converted to AC electrical conductivity $(\sigma)$ using the Equation (3.1):

$$
\sigma=K\left(\frac{1}{\mathrm{R}} \cdot \frac{\mathrm{L}}{\mathrm{S}}\right)
$$

where $\mathrm{R}=$ electrical resistance

$\mathrm{L}=$ distance between the two electrodes

$\mathrm{S}=$ surface area of the electrode immersed in the melt

$\mathrm{K}=$ cell constant that was determined by calibrating the instrument using three different concentrations of $\mathrm{KCl}$ standard solution.

\subsection{Crystallinity by X-Ray Diffraction (XRD) and Scanning Electron Microscopy (SEM)}

Scintag powder XRD (with $\mathrm{Cu} K_{\alpha}$ radiation at a step scan rate of $0.03 \mathrm{deg} / \mathrm{min}$ ) and JEOL T330A SEM (operated at 15-20 kV) were performed to provide insight into the type and/or extent of crystallization in both annealed and CCC-treated samples.

\subsection{Dissolution Tests}

The chemical durability for all four MS-LAW glasses was determined by measuring the dissolution rate of rectangular glass samples $(1 \mathrm{~cm} \times 1 \mathrm{~cm} \times 1 \mathrm{~cm})$ immersed in $100 \mathrm{ml}$ of deionized water (DIW) held at $90^{\circ} \mathrm{C}$. This method is not a standard test protocol, which is used as a glass screening tool to sort out the durable glasses, but the results are in general good agreement with PCT and VHT results in most case. Duplicate samples for both annealed and CCC glasses were tested. The samples were removed from the solution after $4,8,16$, and 32 days, rinsed, dried in an oven at $90^{\circ} \mathrm{C}$ for an hour, and then weighed to determine the weight loss if any as compared to the initial weight. The dissolution rate $(D R)$ is given by Equation 3.2:

$$
D R=\frac{\Delta W}{S A \times t}
$$

where $S A$ is the surface area $\left(\mathrm{cm}^{2}\right)$ of the sample and $t$ is the time (min) that the sample was immersed in the test solution at $90^{\circ} \mathrm{C}$. The mass loss $(\Delta W)$ is $W_{i}-W_{t}$, where $W_{i}$ is the initial mass and $W_{t}$ is the mass of the same specimen after a time $t$ in DIW at $90^{\circ} \mathrm{C}$. 


\subsection{Product Consistency Test (PCT)}

The PCT was performed on the MS-LAW-1 glass to assess chemical durability via the PCT (ASTM 1998). The current PCT specification for Hanford LAW glass (borosilicate-based) is that the normalized release of sodium, silicon, and boron shall be less than $2 \mathrm{~g} / \mathrm{m}^{2}$ using a 7-day test at $90^{\circ} \mathrm{C}$ (DOE 2001). The PCT was conducted in triplicate for both annealed and CCC glasses to assess the impact of thermal history on product quality. Also included in this experimental test matrix were the Environmental Assessment (EA) glass (Jantzen et al. 1993), the Approved Reference Material (ARM-1) glass, and blanks. Samples were ground, washed, and prepared according to procedure. Fifteen $\mathrm{mL}$ of Type I American Society for Testing and Materials (ASTM) water were added to $1.5 \mathrm{~g}$ of glass in stainless steel vessels. The vessels were closed, sealed, and placed in an oven at $90 \pm 2{ }^{\circ} \mathrm{C}$. Samples were left at $90^{\circ} \mathrm{C} \pm$ $2^{\circ} \mathrm{C}$ for 7 days. The resulting solutions (once cooled) were sampled (filtered and acidified), labeled, and analyzed. Normalized release rates were calculated based on the targeted composition using the average of the logs of the leachate concentrations.

\subsection{Vapor Hydration Test (VHT)}

The VHT is performed by exposing monolithic samples to saturated water vapor at elevated temperatures (typically $90^{\circ} \mathrm{C}$ to $300^{\circ} \mathrm{C}$ ) in a sealed vessel as shown schematically in Figure 3.1. This environment used in VHTs greatly accelerates the progression of glass corrosion by water and can result in the formation of alteration phases. The principal uses of the test are as follows: 1) as a screening tool to quickly determine if a glass is likely to corrode at an extreme rate, 2) as a convenient means of generating alteration phases for analysis within a short period, and 3) as a measure of the alteration rate at elevated temperatures.

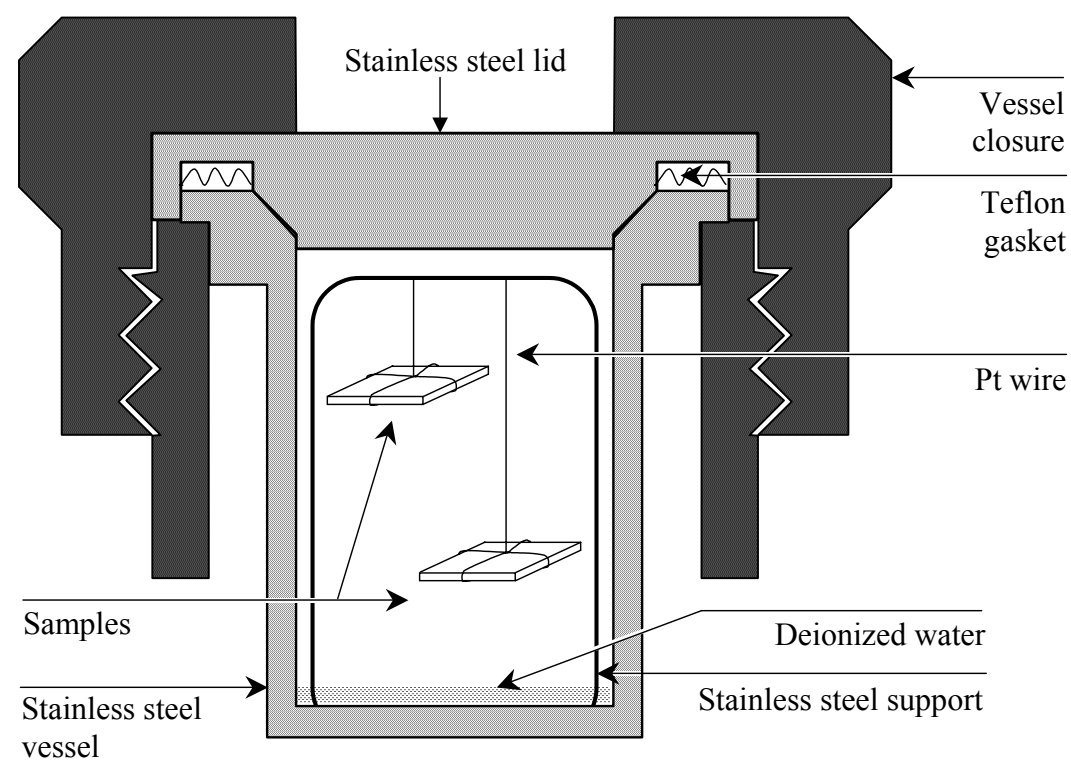

Figure 3.1. Apparatus for Conducting VHTs 
The VHTs were performed according to a PNNL technical procedure. ${ }^{\text {(a) }}$ Samples with dimensions of $10 \times 10 \times 1.5 \mathrm{~mm}$ were prepared from heat-treated glass bars with a diamond-impregnated saw. All sides were polished to 600-grit surface finishes with silicon carbide paper. Samples, stainless steel vessels, lids, and supports were cleaned, and samples were suspended from stainless steel supports on Pt wire. An amount of DIW, predetermined to be appropriate for the vessel size, the temperature, and the number of samples in the vessel, was added to each vessel. The sealed vessels were held at constant temperature in convection ovens for a preset time, removed, weighed, and quenched in water. After the test termination, samples were removed from the vessels and examined for the presence of alteration products with optical microscopy (OM).

The mass of glass converted to alteration products per unit surface area, $m_{a}$, was calculated from the difference between initial glass thickness and the remaining glass thickness determined from sample cross sections with OM and image analysis (IA). The thickness of the remaining glass layer, $d_{r}$, was determined by performing 10 measurements equally distributed across the specimen and used to calculate $m_{a}$ according to Equation 3.3:

$$
m_{a}=\frac{1}{2} \rho\left(d_{i}-d_{r}\right)=\frac{m_{i}}{2 w_{i} l_{i}}\left(1-\frac{d_{r}}{d_{i}}\right)
$$

where $m_{i}=$ initial sample mass

$w_{i}$ and $l_{i}=$ sample width and length

$\rho=$ bulk glass density

$d_{i}=$ initial glass thickness.

\subsection{Centimeter Scale Melter (CSM) Tests with Simulated LAW Feed}

For a given glass composition, the fate of sulfur depends on the feed chemistry and heating conditions. The experimental work described thus far has been based on crucible-scale melts using dry raw materials. Vienna et al. (2002a) have demonstrated that partitioning differences occur between dry feed and slurry feed systems. To assess sulfur partitioning of the LAW iron phosphate system, the CSM test was performed. Of particular interest was the potential formation of a sulfate salt layer upon continuous slurry-feed melting of the high-sulfur LAW based feed.

Table 3.4 lists the chemical compounds used to prepare simulated Hanford LAW. First, all the nitrate compounds (the first six compounds in Table 3.4) were thoroughly mixed in $200 \mathrm{~mL}$ DIW in a container with 1-L marking. Then, the remaining compounds were added while mixing in the order given in Table 3.4. Finally, DIW was added to make the total volume 1 L to produce 1 -L LAW slurry at 100-g oxides and halogens per liter slurry. The present recipe is not intended to be an exact simulation of any particular Hanford liquid LAW, but gives a good simulant for the melting behavior of LAW in general.

The glass formers required to form the MS-LAW-1 composition at 27 mass $\%$ waste loading is given in Table 3.5. The glass-forming chemicals were added to the LAW simulant to prepare the LAW glass slurry feed.

(a) Vapor-phase Hydration Test Procedure, GDL-VHT, Rev. 1, Pacific Northwest National Laboratory, Richland, Washington (1999). 
Table 3.4. Recipe for Simulated Hanford LAW

\begin{tabular}{||l|l|c||}
\hline \multicolumn{1}{|c|}{ Compound Name } & \multicolumn{1}{c|}{ Formula } & Mass, $\mathbf{g}$ \\
\hline Aluminum nitrate nonahydrate & $\mathrm{Al}\left(\mathrm{NO}_{3}\right)_{3}-9 \mathrm{H}_{2} \mathrm{O}(60 \%$ soln $)$ & 53.750 \\
\hline Bismuth nitrate & $\mathrm{Bi}\left(\mathrm{NO}_{3}\right)_{3}-5 \mathrm{H}_{2} \mathrm{O}$ & 0.031 \\
\hline Calcium nitrate tetrahydrate & $\mathrm{Ca}\left(\mathrm{NO}_{3}\right)_{2}-4 \mathrm{H}_{2} \mathrm{O}$ & 0.379 \\
\hline Chromium nitrate nonahydrate & $\mathrm{Cr}\left(\mathrm{NO}_{3}\right)_{3}-9 \mathrm{H}_{2} \mathrm{O}$ & 1.508 \\
\hline Iron nitrate, nonahydrate & $\mathrm{Fe}\left(\mathrm{NO}_{3}\right)_{3}-9 \mathrm{H}_{2} \mathrm{O}$ & 0.423 \\
\hline Nickel nitrate hexahydrate & $\mathrm{Ni}\left(\mathrm{NO}_{3}\right)_{2}-6 \mathrm{H}_{2} \mathrm{O}$ & 0.045 \\
\hline Sodium chloride & $\mathrm{NaCl}$ & 1.005 \\
\hline Sodium fluoride & $\mathrm{NaF}$ & 3.510 \\
\hline Sodium dihydrogen phosphate & $\mathrm{NaH}_{2} \mathrm{PO}_{4}$ & 12.977 \\
\hline Sodium sulfate & $\mathrm{Na}_{2} \mathrm{SO}_{4}$ & 16.688 \\
\hline Sodium hydroxide & $\mathrm{NaOH}(50 \%$ soln $)$ & 135.025 \\
\hline Sodium silicate & $\mathrm{Na}_{2} \mathrm{SiO}_{3}$ & 1.083 \\
\hline Sodium EDTA & $\mathrm{Na}_{2} \mathrm{EDTA}$ & 0.133 \\
\hline Sodium nitrite & $\mathrm{NaNO}_{2}$ & 1.304 \\
\hline Sodium carbonate & $\mathrm{Na}_{2} \mathrm{CO}_{3}$ & 1.459 \\
\hline Potassium carbonate & $\mathrm{K}_{2} \mathrm{CO}_{3}$ & 0.724 \\
\hline & & 230.044 \\
\hline
\end{tabular}

Table 3.5. Glass-Forming Chemicals Per Liter of LAW Slurry to Produce the MS-LAW-1 Glass at 27 mass\% Waste Loading

\begin{tabular}{||c|r||}
\hline Raw Materials & Mass, $\mathbf{g}$ \\
\hline $\mathrm{Al}(\mathrm{OH})_{3}$ & 82.540 \\
\hline $\mathrm{Bi}_{2} \mathrm{O}_{3}$ & 8.318 \\
\hline $\mathrm{CaCO}_{3}$ & 2.074 \\
\hline $\mathrm{Cr}_{2} \mathrm{O}_{3}$ & 10.824 \\
\hline $\mathrm{CaF}_{2}$ & 14.243 \\
\hline $\mathrm{FePO}_{4}-\times \mathrm{H}_{2} \mathrm{O}\left(2 \mathrm{wt} \% \mathrm{H}_{2} \mathrm{O}\right)^{(\mathrm{a})}$ & 48.024 \\
\hline$\left(\mathrm{NH}_{4}\right)_{2} \mathrm{HPO}_{4}{ }^{(\mathrm{b})}$ & 142.632 \\
\hline $\mathrm{SiO}_{2}$ & 43.911 \\
\hline $\mathrm{La}_{2} \mathrm{O}_{3}$ & 2.778 \\
\hline $\mathrm{ZrO}_{2}$ & 8.333 \\
\hline $\mathrm{Sum}$ & 363.677 \\
\hline
\end{tabular}

(a) $2 \mathrm{wt} \% \mathrm{H}_{2} \mathrm{O}$ was obtained from drying test.

(b) Need to grind into fine powder for easy dissolution in the slurry. 
The CSM was developed to better simulate those processes that are important to determining the behavior of sulfur in a slurry-fed melter system with batch heating from the glass melt below the batch cold cap (Darab et al. 2001) and was used extensively in the glass (borosilicate) development for the Idaho National Engineering and Environmental Laboratory (INEEL) sodium-bearing waste (SBW) (Vienna et al. 2002a). Figure 3.2 shows a schematic diagram of the CSM used for the study with simulated LAW glass feed in the laboratory.

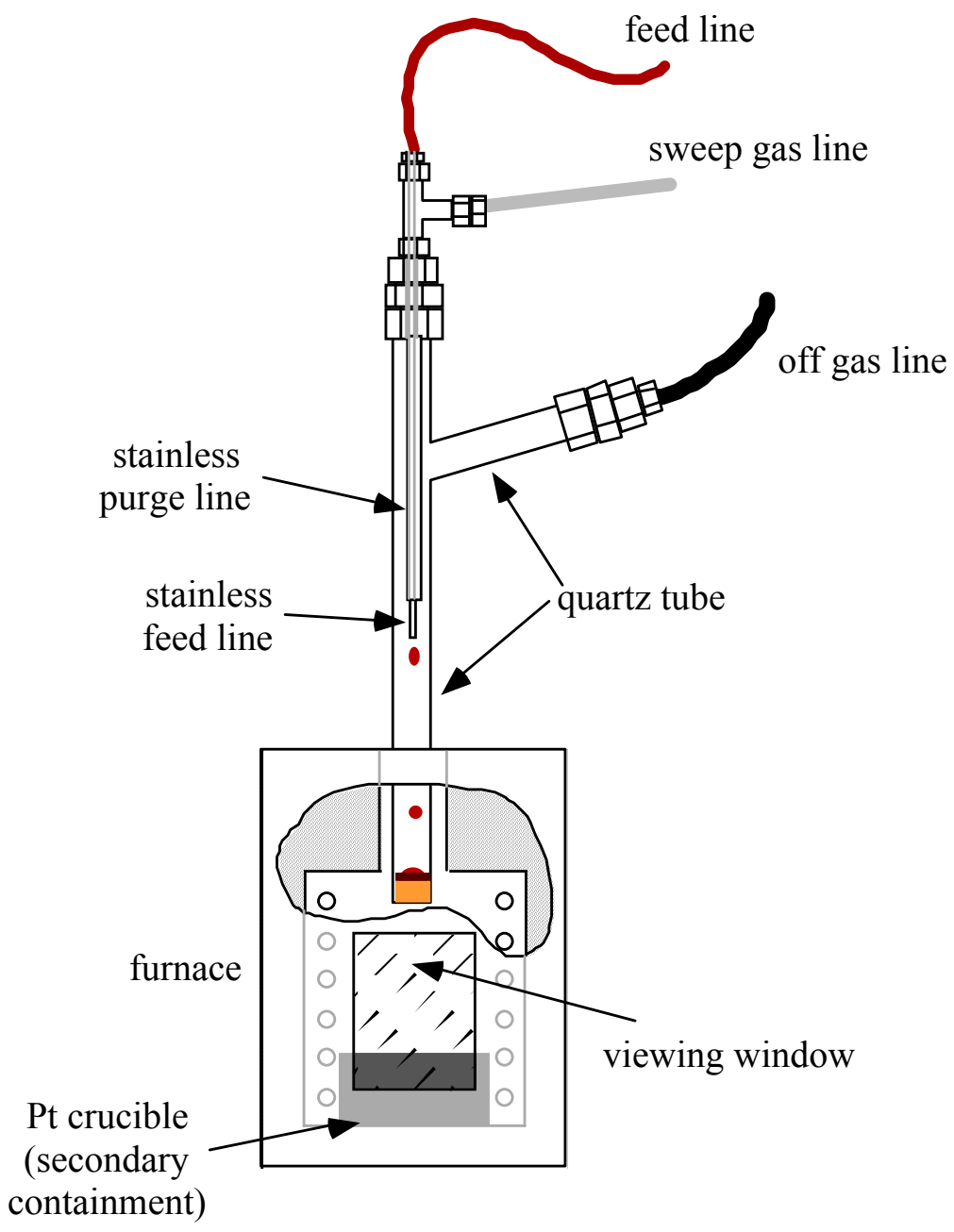

Figure 3.2. Schematic Diagram of the Centimeter-Scale Melter (CSM). Typically, the quartz tube assembly is gradually lowered further into the furnace as the melt level increases with time. For clarity, a cut-away view of part of the furnace is shown.

The CSM consists of a main vessel of 1-in.-diameter fused silica tubing as shown in Figure 3.2. This tubing is sealed at the bottom, open at the top, and has a side-arm near the top for gas removal. The tube is suspended in a custom-designed box furnace equipped with a fused silica window to observe the experiment. The melter feed is introduced through the top of the crucible through a $1 / 8$-in. stainless steel tube that extends past the off-gas side-arm and is roughly centered in the crucible.

To perform the CSM tests, slurry feed was stirred in a beaker on a stir-plate. A Tygon tube with a known inner diameter was used to draw the feed directly from the beaker, through a systolic pump, and to the $1 / 8$-in. stainless steel feed tube. The feed drops from the feed tube to the melt surface where it is heated 
from the glass melt below. Although the plenum temperature is not controlled, the crucible can be placed fully into the furnace, which is held at a typical glass-melting temperature. Even more typically, it can be adjusted so that the glass melt/cold cap interface is maintained at the furnace hot-zone chamber-top refractory interface to assure that the primary source of heat to the melting batch comes from the glassmelt pool below.

The CSM set-up can also be used to estimate the off-gas released during melting (see Darab et al. [2001]) for a detailed description of various setups for the off-gas treatment/analyses. However, the present study LAW phosphate glass feed was aimed at monitoring any indication of salt formation during slurry-fed melting.

\subsection{One-Component-at-a-Time Variation Study}

Information on the effect of glass components on the glass properties, such as viscosity, electrical conductivity, and chemical durability, is critical for the glass-formulation efforts to develop the glass compositions that satisfy the processing and product requirements. Many of the past studies on borosilicate glasses for vitrification of HLW and LAW have focused on developing the glass composition-property models (Hrma et al. 1994; Gan and Pegg 2001a; Gan and Pegg 2001b; Vienna et al. $2002 \mathrm{~b}$ ). Also, some basic composition-property models for general glass properties are available for a wide range of silicate-based glasses (Scholtze 1990). However, there have been no systematic studies on the effect of glass composition on phosphate glass properties that can assist the formulation via model predictions of phosphate glasses for HLW or LAW vitrification. As an initial effort to investigate the effect of glass composition on the chemical durability, a one-component-at-a-time variation study was started. The study was originally planned to assess PCT and crystallinity of as-melted (quenched) and $\mathrm{CCC}$ treated glasses. However, because of time and fund limitations, only the glass preparation and chemical analysis of glass compositions were completed within the present study.

The base glass for this study (LAPG1-Base) was formulated to have 20 mass $\% \mathrm{Na}_{2} \mathrm{O}$ in glass at 26.67 mass $\%$ waste loading. Table 3.6 provides the compositions of waste, additive, and resulting glass, and the mass \% variation from a base glass in the present one-component-at-a-time variation study test matrix. The waste composition in Table 3.6 is given as the normalized concentration after deleting the components with $<0.01$ mass \% (Others component) from Table 3.1. While the concentration of each component was varied as shown in Table 3.6, the concentrations of all other components were kept in relative proportions as given in the base glass.

The glasses were prepared from dry raw materials of phosphates, carbonates, sodium sulfate, sodium halides, and oxides. The primary materials used to provide $\mathrm{P}_{2} \mathrm{O}_{5}$ were iron phosphate $\left(\mathrm{FePO}_{4}\right)$ and sodium meta-phosphate $\left(\mathrm{NaPO}_{3}\right)$. The additional $\mathrm{P}_{2} \mathrm{O}_{5}$ in certain glasses with low $\mathrm{Fe}_{2} \mathrm{O}_{3}$ or/and $\mathrm{Na}_{2} \mathrm{O}$ concentration was supplied from aluminum meta-phosphate $\left(\mathrm{AlP}_{3} \mathrm{O}_{9}\right)$ or/and phosphorous oxide $\left(\mathrm{P}_{2} \mathrm{O}_{5}\right)$. The batch composition was adjusted to compromise the use of these two materials because aluminum meta-phosphate can cause slow melting of a glass batch due to its refractory nature, and phosphorous oxide can cause a high rate of volatilization during melting. It is difficult to handle the phosphorous oxide because of its hydroscopic nature. The glass was first melted at a desired melting temperature for $1.5 \mathrm{~h}$ in a covered Pt crucible and poured on a steel plate. The actual melting temperature used to prepare each glass was determined based on examining the presence of any fuming during melting and any unreacted batch materials left within the glass upon pouring. The glass from the first melting was crushed and ground in a tungsten carbide mill for better homogeneity and remelted at the same temperature for another $1.5 \mathrm{~h}$. 
Table 3.6. Formulation of Base Glass and Component Variation in OneComponent Study Test Matrix

\begin{tabular}{||c|c|c|c|c||}
\hline Component & Waste & Additive & $\begin{array}{c}\text { LAPG1-Base } \\
\text { Glass }\end{array}$ & $\begin{array}{c}\text { Mass\% Variation } \\
\text { from Base Glass }\end{array}$ \\
\hline $\mathrm{Al}_{2} \mathrm{O}_{3}$ & 4.40 & 10 & 8.51 & $-6,-3,+3,+6$ \\
\hline $\mathrm{SiO}_{2}$ & 0.53 & & 0.14 & \\
\hline $\mathrm{Cl}$ & 0.59 & & 0.16 & \\
\hline $\mathrm{Cr}_{2} \mathrm{O}_{3}$ & 0.29 & & 0.08 & \\
\hline $\mathrm{F}$ & 1.59 & & 0.42 & \\
\hline $\mathrm{Fe}_{2} \mathrm{O}_{3}$ & & 20 & 14.67 & $-6,-3,+3,+6$ \\
\hline $\mathrm{K}_{2} \mathrm{O}$ & 0.50 & & 0.13 & \\
\hline $\mathrm{Na}_{2} \mathrm{O}$ & 74.98 & & 20.00 & $-3,+3,+6$ \\
\hline $\mathrm{P}_{2} \mathrm{O}_{5}$ & 7.69 & 70 & 53.38 & $-8,-4,+4,+8$ \\
\hline $\mathrm{SO}_{3}$ & 9.43 & & 2.51 & \\
\hline $\mathrm{Sum}^{2}$ & 100.00 & 100 & 100.00 & \\
\hline \hline
\end{tabular}

To check that the as-melted glasses have the composition corresponding to the target compositions, each sample was subjected to chemical analysis by inductively coupled plasma-atomic emission spectroscopy (ICP-AES) for concentrations of cations. Glass was dissolved using a lithium metaborate fusion / HNO3 uptake digestion. Anion analyses $(\mathrm{F}$ and $\mathrm{Cl})$ were not performed on these glasses. 


\subsection{Results and Discussion}

This section provides the results and general discussion of the tests described in Section 3.0.

\subsection{Chemical Composition}

Table 4.1 compares the target and measured composition for the MS-LAW-1 glass. In general, the results indicate that the targeted composition was met. The overall sum of oxides is well within acceptable limits $(100 \pm 5 \%)$. One of the more noticeable differences between targeted and measured concentrations is $\mathrm{SO}_{3}$. The measured value indicates that approximately $58 \%$ of the $\mathrm{SO}_{3}$ was volatile (or $42 \%$ retention). This relatively low sulfate retention could be a concern assuming that the integrated flowsheet has $\mathrm{SO}_{3}$ as a recycle stream to the melter or that the off-gas system was highly susceptible to corrosion. More detailed data and discussion on the effect of glass composition on sulfate retention will be treated in Section 4.8.

Table 4.1. Target Composition and Measured Composition for the MS-LAW-1 Glass

\begin{tabular}{||c|c|c||}
\hline \hline Oxide (mass\%) & Target & Measured \\
\hline $\mathrm{Al}_{2} \mathrm{O}_{3}$ & 15.8 & 14.6 \\
\hline $\mathrm{Cl}$ & 0.2 & 0.334 \\
\hline $\mathrm{Cr}_{2} \mathrm{O}_{3}$ & 3.0 & 3.15 \\
\hline $\mathrm{F}$ & 1.0 & 0.08 \\
\hline $\mathrm{Na}_{2} \mathrm{O}$ & 20.3 & 18.6 \\
\hline $\mathrm{P}_{2} \mathrm{O}_{5}$ & 28.8 & 28.4 \\
\hline $\mathrm{SiO}_{2}$ & 12.0 & 17.1 \\
\hline $\mathrm{SO}_{3}$ & 2.6 & 1.1 \\
\hline $\mathrm{Bi}_{2} \mathrm{O}_{3}$ & 2.3 & 2.0 \\
\hline $\mathrm{Fe}_{2} \mathrm{O}_{3}$ & 6.8 & 6.96 \\
\hline $\mathrm{La}_{2} \mathrm{O}_{3}$ & 0.8 & 0.67 \\
\hline $\mathrm{ZrO}$ & 2.3 & 1.02 \\
\hline $\mathrm{CaO}_{2}$ & 4.1 & 4.7 \\
\hline $\mathrm{Total}^{2}$ & 100.00 & 98.71 \\
\hline
\end{tabular}

Another notable difference is the elevated measured $\mathrm{SiO}_{2}$ concentration (17.1 mass\%) as compared to target (12.0 mass\%). It is not clear whether this elevated concentration is a result of the dissolution of the dense fused-silica crucible used to fabricate the MS-LAW-1 glass at UMR because there was no evidence of noticeable dissolution of crucible after melting as discussed in Section 5.3. Although limited dissolution may have occurred, its impact on the measured properties and, perhaps more importantly, the conclusions drawn in this report are not of practical concern.

\subsection{Selected Basic Glass Properties}

Table 4.2 lists the density and thermal expansion of MS-LAW-1, MS-LAW-1-1, and MS-LAW-1-2 glasses. The densities of the annealed glasses are approximately $2.8 \mathrm{~g} / \mathrm{cm}^{3}$, increasing by less than $2 \%$ for samples cooled according to the CCC profile. 
Table 4.2. Density, Thermal-Expansion Coefficient (TEC) and Liquidus Temperature $\left(\mathrm{T}_{\mathrm{L}}\right)$ of Iron Phosphate Waste Glasses

\begin{tabular}{|c|c|c|c|c|}
\hline & \multicolumn{2}{|c|}{\begin{tabular}{l|l} 
Density & $\left(\mathrm{g} / \mathrm{cm}^{3}\right)$
\end{tabular}} & \multirow{2}{*}{$\begin{array}{c}\text { TEC for } 35-300{ }^{\circ} \mathrm{C} \\
\left(\times 10^{-7} /{ }^{\circ} \mathrm{C}\right)\end{array}$} & \multirow{2}{*}{$\begin{array}{c}\mathbf{T}_{\mathrm{L}} \\
\left({ }^{\circ} \mathrm{C}\right)\end{array}$} \\
\hline & Annealed & $\mathrm{CCC}$ & & \\
\hline MS-LAW-1 & 2.81 & 2.82 & 135 & Not measured \\
\hline MS-LAW-1-1 & 2.76 & 2.82 & 138 & $762 \pm 10$ \\
\hline MS-LAW-1-2 & 2.83 & 2.88 & Not measured & Not measured \\
\hline
\end{tabular}

The DTA curves for MS-LAW-1, MS-LAW-1-1, and MS-LAW-1-2 are given in Appendix A. Most notable is the absence of any crystallization peaks in the DTA traces. The glass-transition temperature for these glasses was 475 to $500^{\circ} \mathrm{C}$.

High-temperature viscosity and AC electrical conductivity data are summarized in Table 4.3 for MSLAW-1-1. Figure 4.1 compares the viscosity for MS-LAW-1-1 with that for other phosphate glasses, and Figure 4.2 compares the electrical conductivity for MS-LAW-1-1 with that for SBW-22-20. Based on viscosity data, the recommended melting temperature for MS-LAW-1-1 glass would be 1150 to $1200^{\circ} \mathrm{C}$. The electrical conductivity at this temperature range is within the recommended range of borosilicate melts for use in Joule-heated melters.

Table 4.3. High Temperature Viscosity and AC Electrical Conductivity for MS-LAW-1-1 Melt

\begin{tabular}{||c|c|c||}
\hline $\begin{array}{c}\text { Temperature } \\
\left({ }^{\circ} \mathbf{C}\right)\end{array}$ & $\begin{array}{c}\text { Viscosity } \\
\text { (poise) }\end{array}$ & $\begin{array}{c}\text { Conductivity @ } \mathbf{~ k H z} \\
(\mathbf{S} / \mathbf{m})\end{array}$ \\
\hline 900 & --- & 53.1 \\
\hline 950 & --- & 61.6 \\
\hline 1000 & --- & 69.7 \\
\hline 1050 & --- & 77.4 \\
\hline 1100 & --- & 83.1 \\
\hline 1150 & 61.1 & 89.3 \\
\hline 1200 & 42.0 & 94.2 \\
\hline 1250 & 29.8 & 101.3 \\
\hline 1300 & 23.5 & 107.1 \\
\hline 1350 & 17.2 & 113.3 \\
\hline \hline
\end{tabular}




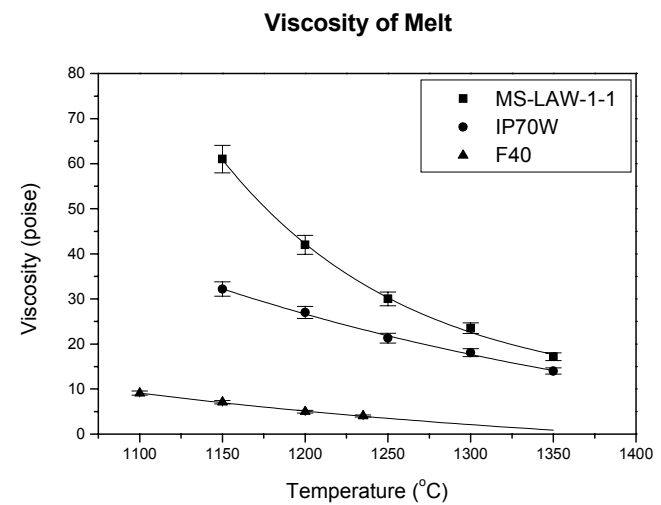

A)

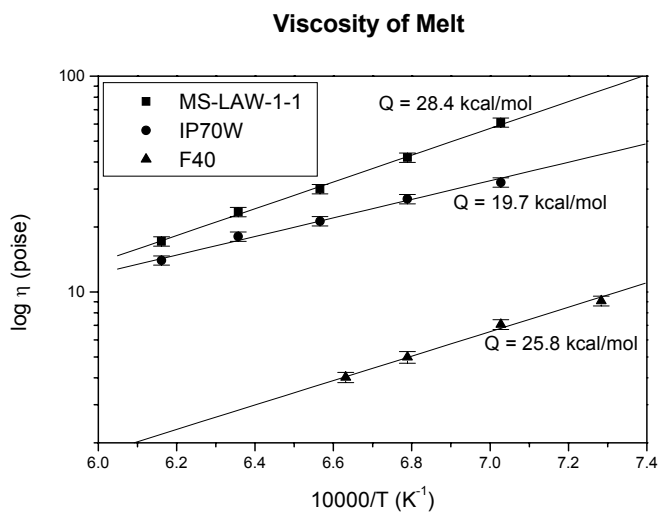

B)

Figure 4.1. A) The Change in Viscosity with Temperature and B) Logarithm of Viscosity Versus 1/T Plot for MS-LAW-1-1 Melt Compared to Other Iron Phosphate Glasses (IP70W: I$P$ glass containing 70 mass\% high chrome waste at Hanford (Huang et al. 2003); F40: $\left.40 \mathrm{Fe}_{2} \mathrm{O}_{3} 60 \mathrm{P}_{2} \mathrm{O}_{5}, \mathrm{~mol} \%\right)$

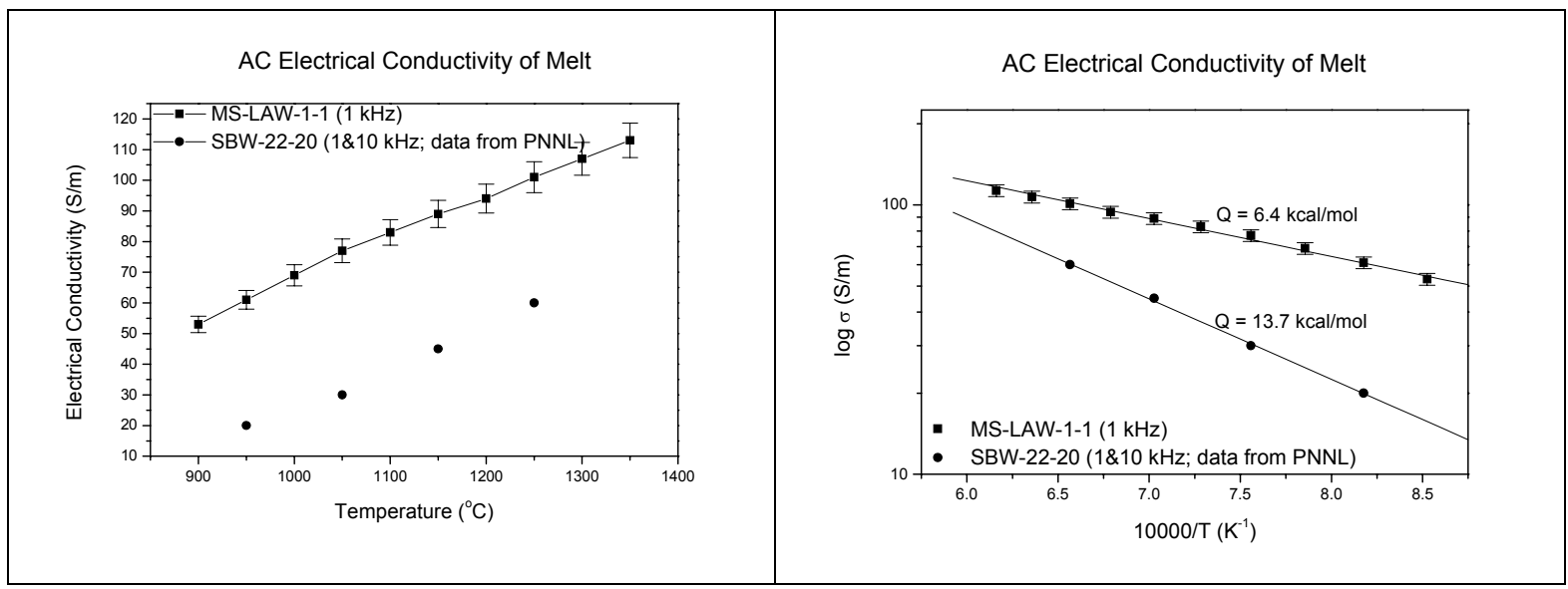

Figure 4.2. AC Electrical Conductivity of MS-LAW-1-1 Compared to SBW-22-20 (Vienna et al. 2002a)

\subsection{XRD and SEM}

Figure 4.3 to Figure 4.10 show the SEM micrographs and XRD patterns of annealed, quenched, and CCC-treated samples of MS-LAW-1, MS-LAW-1-1, and MS-LAW-1-2 glasses. Table 4.4 summarizes the crystalline phases shown in Figure 4.3 to Figure 4.10. The annealed sample of MS-LAW-1 glass had sodium-calcium phosphate $\left(\mathrm{NaCaPO}_{4}\right)$ and $(\mathrm{Cr}, \mathrm{Fe})_{2} \mathrm{O}_{3}$ (solid solution of $\mathrm{Cr}_{2} \mathrm{O}_{3}$ and $\mathrm{Fe}_{2} \mathrm{O}_{3}$ ) whereas the quenched or annealed samples of MS-LAW-1-1 and MS-LAW-1-2 glasses had a small fraction of $(\mathrm{Cr}, \mathrm{Fe})_{2} \mathrm{O}_{3}$ phase only. The CCC-treated MS-LAW-1 glass crystallized the same phases as in the annealed glass, but that of MS-LAW-1-1 and MS-LAW-1-2 glasses crystallized two forms of sodiumiron phosphates $\left[\mathrm{NaFeP}_{2} \mathrm{O}_{7}\right.$ and $\left.\mathrm{Na}_{3} \mathrm{Fe}_{2}\left(\mathrm{PO}_{4}\right)_{3}\right]$. Overall, the total crystallinity was lowest in MS-LAW-1-1 glass in both annealed (or quenched) and CCC-treated samples based on a qualitative comparison of XRD peaks. 


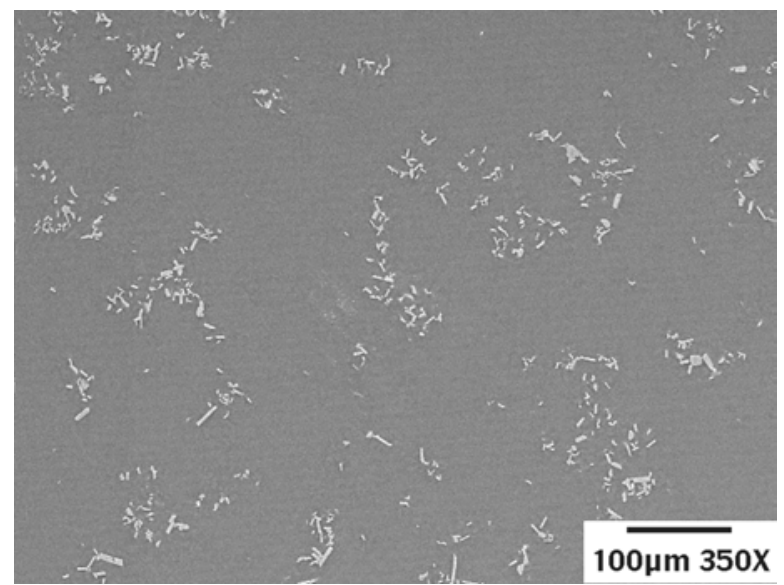

(A) SEM Micrograph

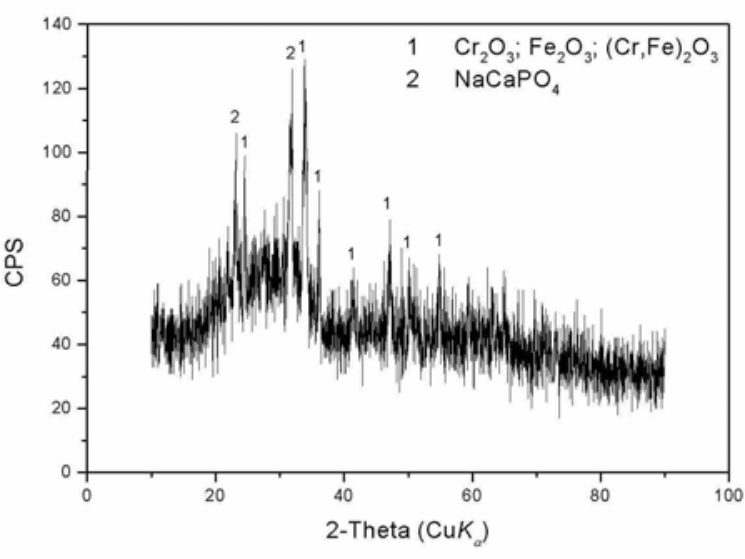

(B) XRD Pattern

Figure 4.3. MS-LAW-1 Annealed Glass

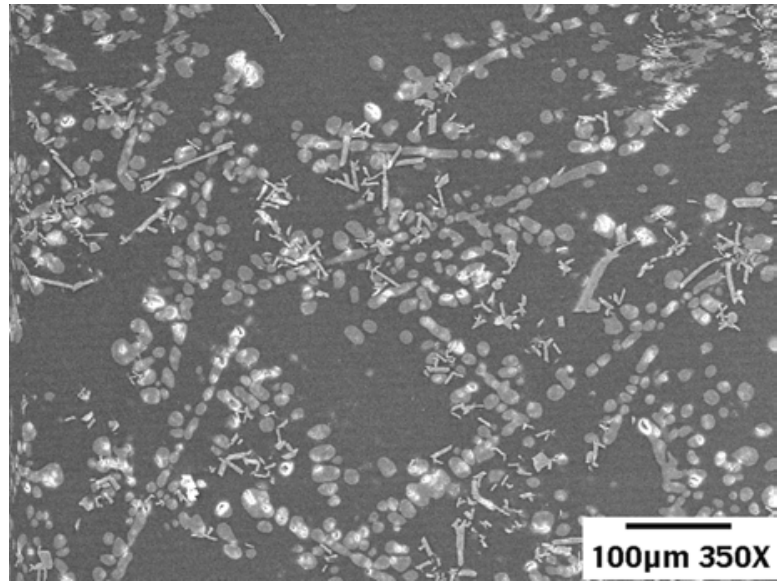

(A) SEM Micrograph

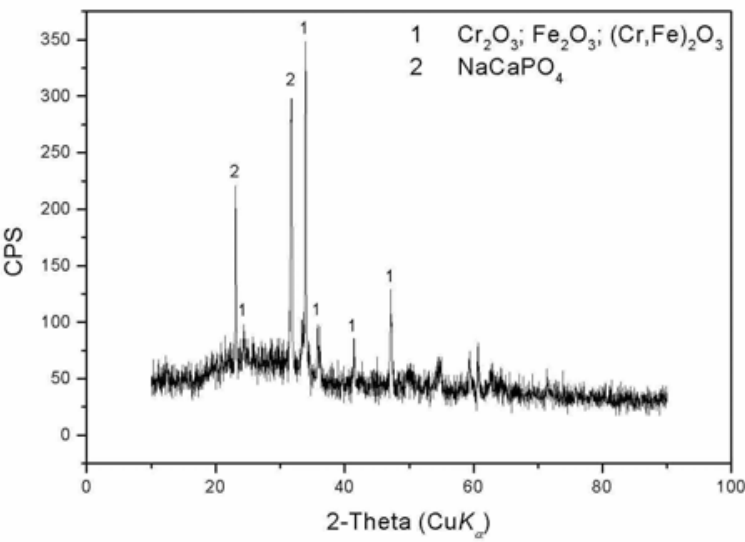

(B) XRD Pattern

Figure 4.4. MS-LAW-1 CCC Treated Glass

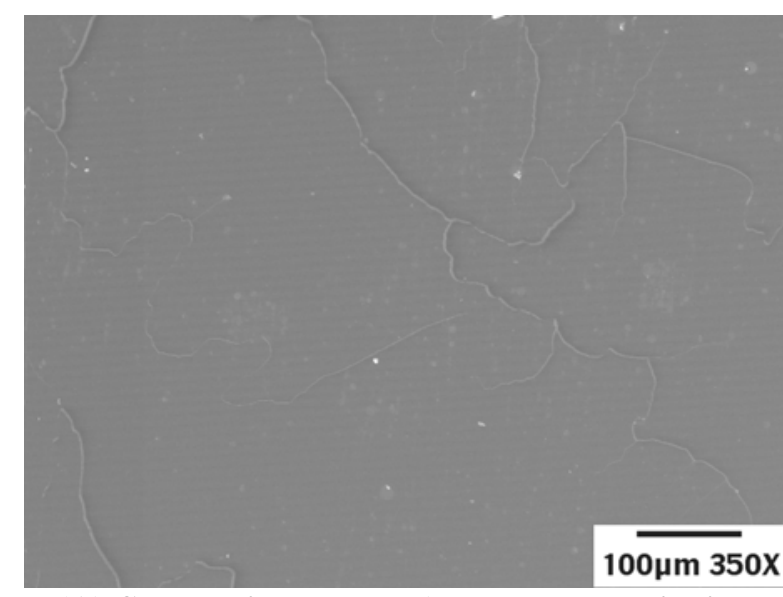

(A) SEM Micrograph (cracks are polishing artifacts)

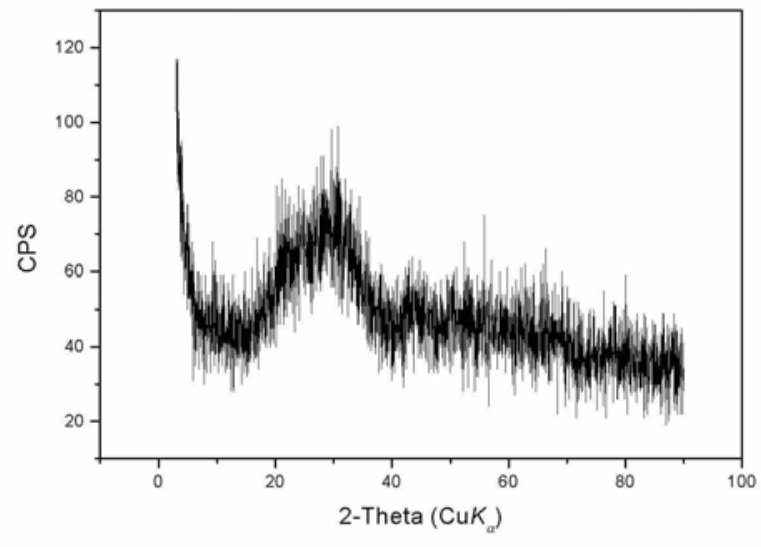

(B) XRD Pattern

Figure 4.5. MS-LAW-1-1 Quenched Glass 


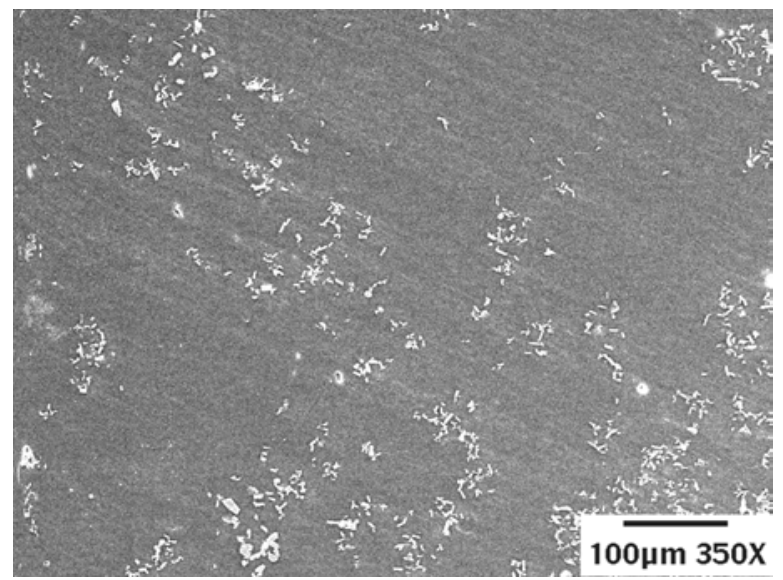

(A) SEM Micrograph

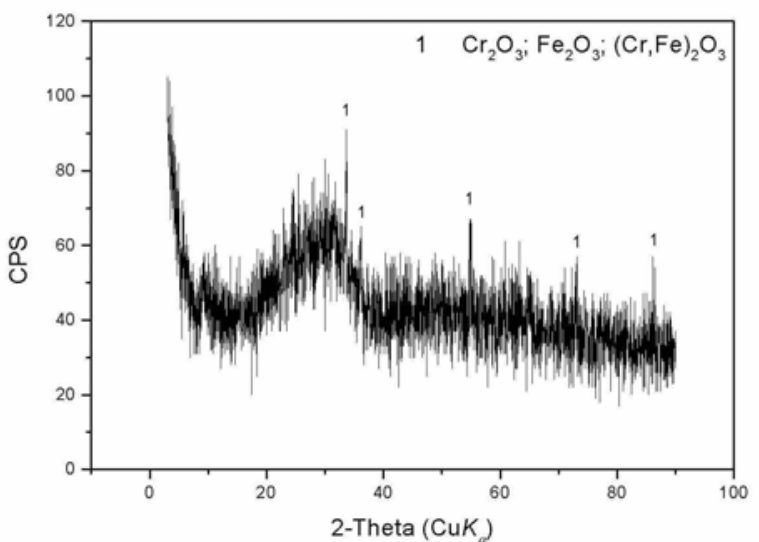

(B) XRD Pattern

Figure 4.6. MS-LAW-1-1 Annealed Glass

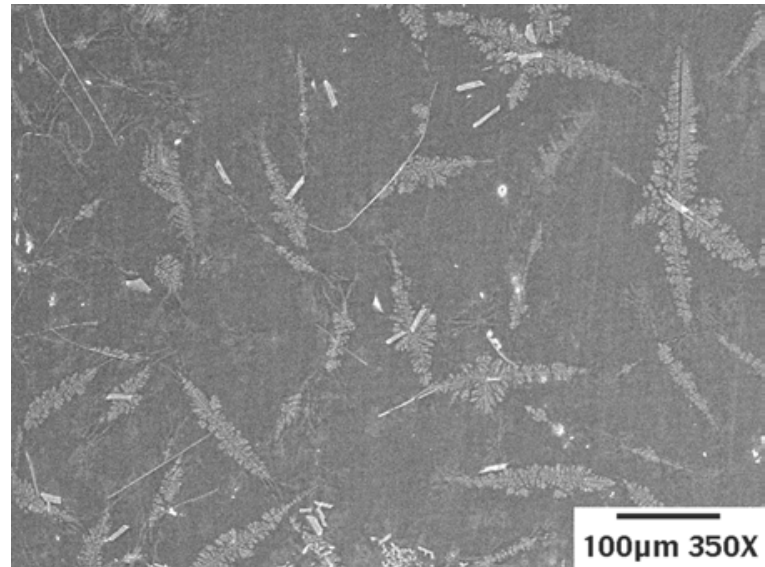

(A) SEM Micrograph

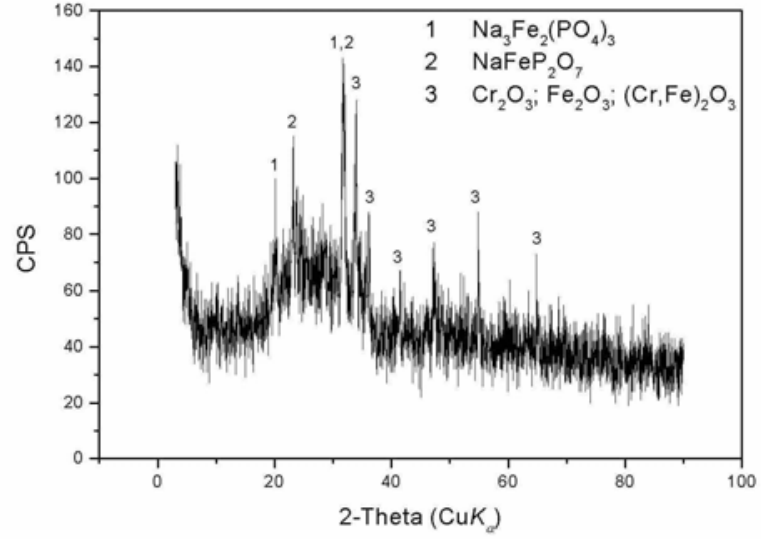

(B) XRD Pattern

Figure 4.7. MS-LAW-1-1 CCC Treated Glass

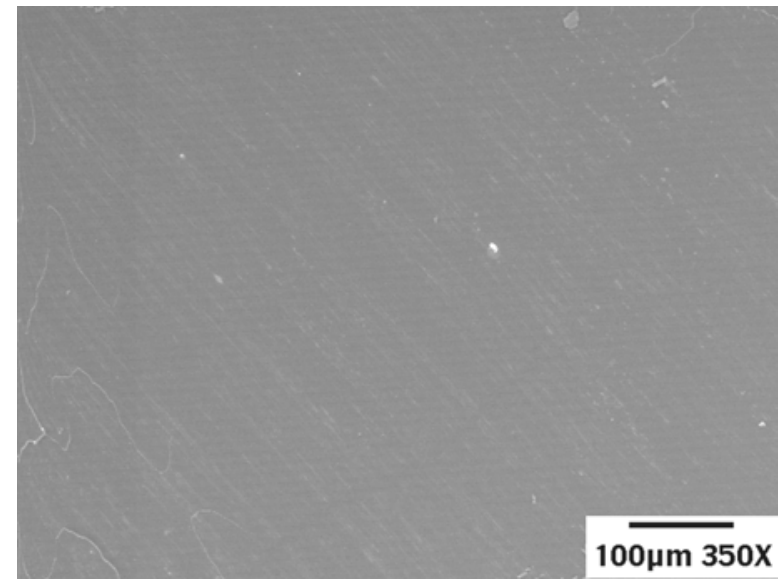

(A) SEM Micrograph (cracks are polishing artifacts)

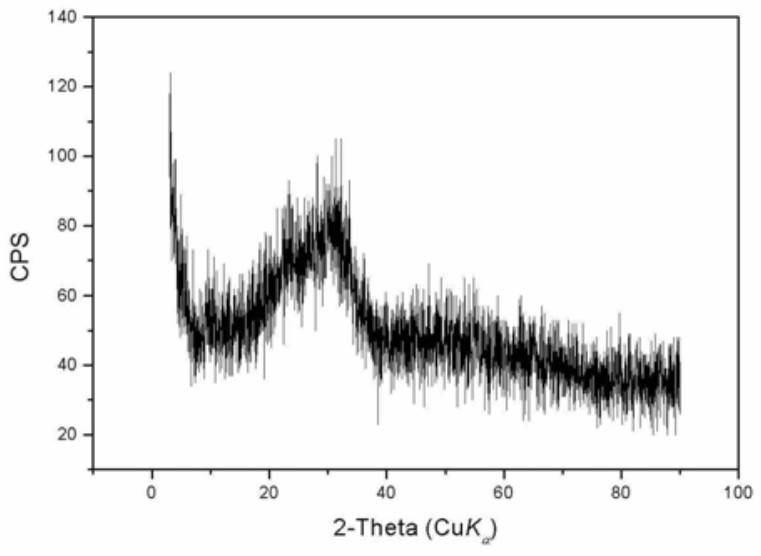

(B) XRD Pattern

Figure 4.8. MS-LAW-1-2 Quenched Glass 


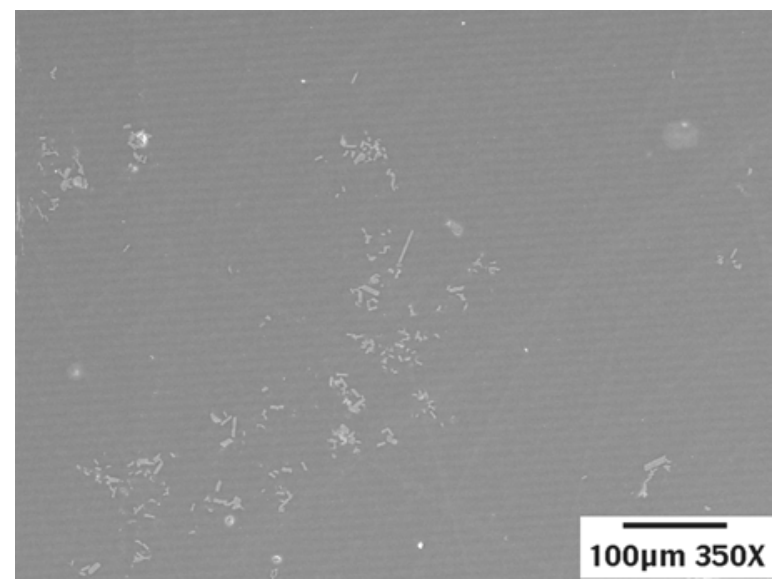

(A) SEM Micrograph

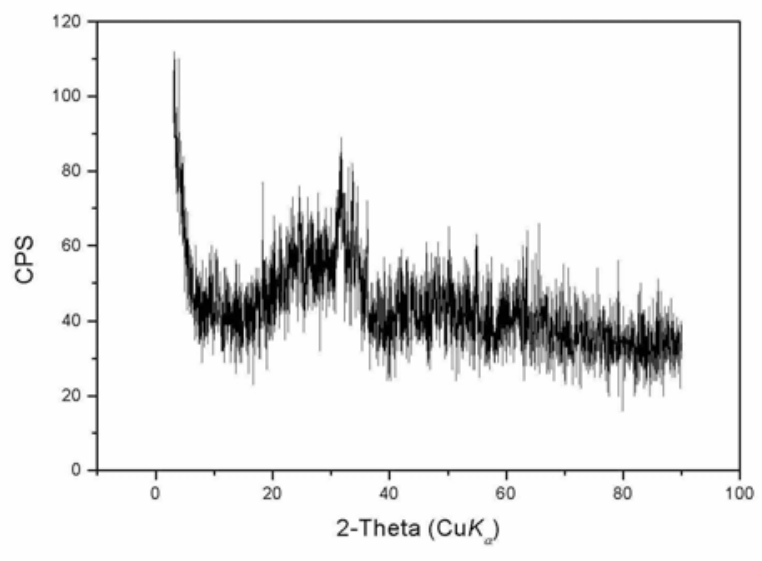

(B) XRD Pattern

Figure 4.9. MS-LAW-1-2 Annealed Glass

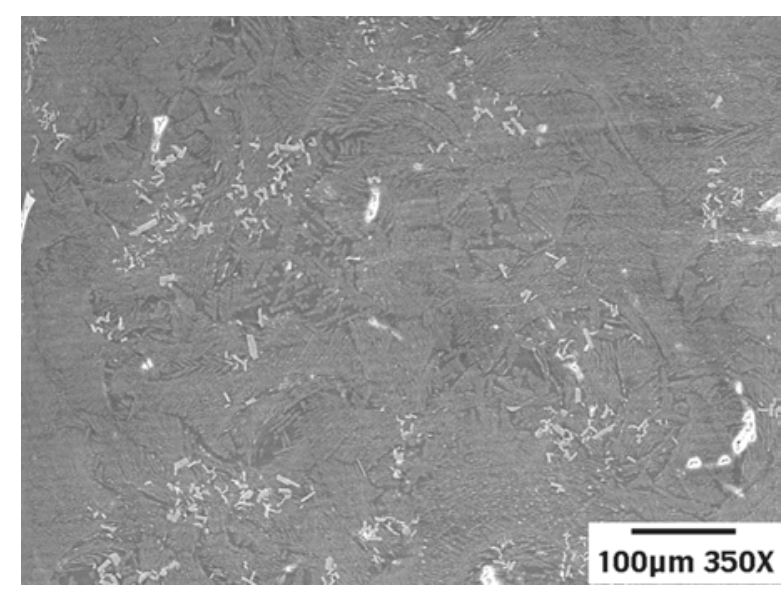

(A) SEM Micrograph

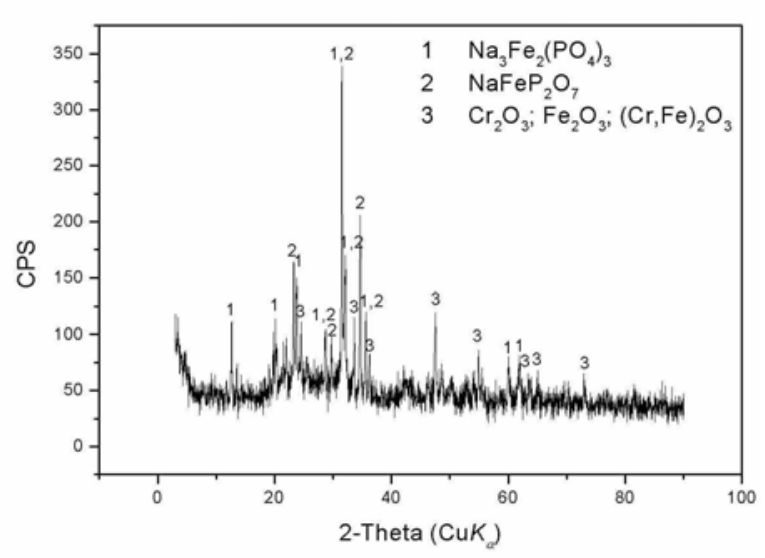

(B) XRD Pattern

Figure 4.10. MS-LAW-1-2 CCC Treated Glass

Table 4.4. Summary of Crystalline Phases Identified by XRD

\begin{tabular}{||c|c|c|c||}
\hline \hline & MS-LAW-1 & MS-LAW-1-1 & MS-LAW-1-2 \\
\hline Quenched & Not analyzed & Trace of $(\mathrm{Cr}, \mathrm{Fe})_{2} \mathrm{O}_{3}$ & Trace of $(\mathrm{Cr}, \mathrm{Fe})_{2} \mathrm{O}_{3}$ \\
\hline Annealed & $(\mathrm{Cr}, \mathrm{Fe})_{2} \mathrm{O}_{3}$ & $(\mathrm{Cr}, \mathrm{Fe})_{2} \mathrm{O}_{3}$ & Trace of $(\mathrm{Cr}, \mathrm{Fe})_{2} \mathrm{O}_{3}$ \\
& $\mathrm{NaCaPO}_{4}$ & & \\
\hline CCC Treated & $(\mathrm{Cr}, \mathrm{Fe})_{2} \mathrm{O}_{3}$ & $(\mathrm{Cr}, \mathrm{Fe})_{2} \mathrm{O}_{3}$ & $(\mathrm{Cr}, \mathrm{Fe})_{2} \mathrm{O}_{3}$ \\
& $\mathrm{NaCaPO}$ & $\mathrm{NaFeP} \mathrm{O}_{7}$ & $\mathrm{NaFeP} \mathrm{O}_{7}$ \\
& & $\mathrm{Na}_{3} \mathrm{Fe}_{2}\left(\mathrm{PO}_{4}\right)_{3}$ & $\mathrm{Na}_{3} \mathrm{Fe}_{2}\left(\mathrm{PO}_{4}\right)_{3}$ \\
\hline
\end{tabular}




\subsection{Dissolution Rate}

Table 4.5 and Table 4.6 summarize the dissolution rates for annealed and CCC treated glasses, respectively. The dissolution rates for the MS-LAW glasses are 10 times smaller than that of EA glass in DIW at $90^{\circ} \mathrm{C}\left(4.9 \mathrm{E}-08 \mathrm{~g} / \mathrm{cm}^{2} / \mathrm{min}\right.$, Kim et al. 2003a).

Table 4.5. Dissolution Rates of Annealed Iron Phosphate Glasses in DIW at $90^{\circ} \mathrm{C}$

\begin{tabular}{|c|c|c|c|c|c|c|c|c|}
\hline \multirow[b]{3}{*}{ Days } & \multicolumn{8}{|c|}{ 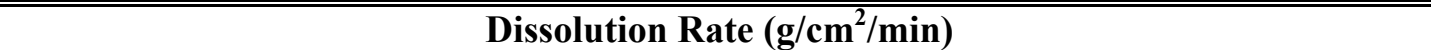 } \\
\hline & \multicolumn{2}{|c|}{ MS-LAW-1 } & \multicolumn{2}{|c|}{ MS-LAW-1-1 } & \multicolumn{2}{|c|}{ MS-LAW-1-2 } & \multicolumn{2}{|c|}{ MS-LAW-1-Simplified } \\
\hline & $\# 1$ & $\# 2$ & $\# 1$ & $\# 2$ & $\# 1$ & $\# 2$ & $\# 1$ & $\# 2$ \\
\hline 4 & $4.5 \mathrm{E}-09$ & $4.0 \mathrm{E}-09$ & $2.3 \mathrm{E}-09$ & $3.1 \mathrm{E}-09$ & $5.9 \mathrm{E}-09$ & $3.7 \mathrm{E}-09$ & $4.5 \mathrm{E}-08$ & $4.6 \mathrm{E}-08$ \\
\hline 8 & $3.5 \mathrm{E}-09$ & $2.5 \mathrm{E}-09$ & $1.2 \mathrm{E}-09$ & $1.3 \mathrm{E}-09$ & $3.5 \mathrm{E}-09$ & $3.4 \mathrm{E}-09$ & $3.4 \mathrm{E}-08$ & $3.3 \mathrm{E}-08$ \\
\hline 16 & $1.8 \mathrm{E}-09$ & $1.3 \mathrm{E}-09$ & $7.4 \mathrm{E}-10$ & $7.9 \mathrm{E}-10$ & (a) & (a) & $2.3 \mathrm{E}-08$ & $2.1 \mathrm{E}-08$ \\
\hline 32 & $1.1 \mathrm{E}-09$ & $8.9 \mathrm{E}-10$ & (a) & (a) & (a) & (a) & $1.3 \mathrm{E}-08$ & $1.0 \mathrm{E}-08$ \\
\hline
\end{tabular}

Table 4.6. Dissolution Rates of Crystallized (CCC) Iron Phosphate Glasses in DIW at $90^{\circ} \mathrm{C}$

\begin{tabular}{|c|c|c|c|c|c|c|c|c|}
\hline \multirow[b]{3}{*}{ Days } & \multicolumn{8}{|c|}{ 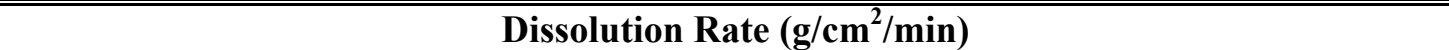 } \\
\hline & \multicolumn{2}{|c|}{ MS-LAW-1 } & \multicolumn{2}{|c|}{ MS-LAW-1-1 } & \multicolumn{2}{|c|}{ MS-LAW-1-2 } & \multicolumn{2}{|c|}{ MS-LAW-1-Simplified } \\
\hline & $\# 1$ & $\# 2$ & $\# 1$ & $\# 2$ & $\# 1$ & $\# 2$ & $\# 1$ & $\# 2$ \\
\hline 4 & $5.6 \mathrm{E}-09$ & $8.3 \mathrm{E}-09$ & $8.3 \mathrm{E}-09$ & $1.1 \mathrm{E}-08$ & \multicolumn{2}{|c|}{ not measured } & $2.0 \mathrm{E}-07$ & $2.2 \mathrm{E}-07$ \\
\hline 8 & $2.9 \mathrm{E}-09$ & 7.0E-09 & $6.4 \mathrm{E}-09$ & $6.7 \mathrm{E}-09$ & \multicolumn{2}{|c|}{ not measured } & $1.7 \mathrm{E}-07$ & $1.9 \mathrm{E}-07$ \\
\hline 16 & $1.8 \mathrm{E}-09$ & $4.3 \mathrm{E}-09$ & $4.1 \mathrm{E}-09$ & $3.9 \mathrm{E}-09$ & \multicolumn{2}{|c|}{ not measured } & $1.0 \mathrm{E}-07$ & $1.1 \mathrm{E}-07$ \\
\hline
\end{tabular}

\subsection{PCT}

Table 4.7 provides the normalized elemental releases for the annealed and CCC MS-LAW-1 glasses. Appendix B provides the elemental leachate-concentration measurements for the solution samples generated by the PCT. Normalized release rates were calculated based on the target glass composition for three elements, $\mathrm{Na} \mathrm{Si}$, and $\mathrm{P}$. $\mathrm{Na}$ and $\mathrm{P}$ are eligible as a representative element for glass dissolution. Normalized release of $\mathrm{Si}$ is included for comparison with that of EA glass that is used as a specification for HLW glasses (DOE 1996). Table 4.7 also includes the normalized release of $\mathrm{Na}$ and Si for the EA glass. The current PCT specification for Hanford LAW glass (borosilicate-based) is that the normalized release of sodium, silicon, and boron shall be $<2 \mathrm{~g} / \mathrm{m}^{2}$ using a 7-day test at $90^{\circ} \mathrm{C}$ (DOE 2001). Given that the phosphate glasses in this study do not contain boron, its normalized release cannot be presented. The normalized release of sodium and silica for both annealed and CCC-treated MS-LAW-1 glasses is well below the current LAW specification and the EA glass limits. It would be natural to investigate the possibility of including the phosphorus release in the PCT specification if the phosphate-based glass is selected as an acceptable waste form.

The increased normalized Na release for the CCC sample suggests that crystallization during slow cooling based on the CCC schedule decreased the glass corrosion resistance (see Table 4.4). Although quantitative measures of the degree of crystallization are not provided in Table 4.3, given that the same crystals are present in both annealed and CCC glasses, it is likely that the percentage of one or both increased when subjected to the slow-cooling schedule. This ultimately resulted in a higher normalized release. Although the normalized releases increased in the CCC-treated glass, they are still well below the acceptable limits. 
Table 4.7. Summary of Normalized Elemental Release for the MS-LAW-1 Glass

\begin{tabular}{||l|c|c|c||}
\hline \hline Glass & $\mathbf{r}_{\mathbf{N a}}\left(\mathbf{g} / \mathbf{m}^{\mathbf{2}}\right)$ & $\mathbf{r}_{\mathbf{S i}}\left(\mathbf{g} / \mathbf{m}^{\mathbf{2}}\right)$ & $\mathbf{r}_{\mathbf{P}}\left(\mathbf{g} / \mathbf{m}^{\mathbf{2}}\right)$ \\
\hline MS-LAW-1 & 0.338 & 0.166 & 0.177 \\
\hline MS-LAW-1CCC & 0.590 & 0.162 & 0.338 \\
\hline LAW glass limit & 2 & 2 & NA \\
\hline EA Glass for HLW & 6.67 & 1.96 & NA \\
\hline
\end{tabular}

As with most borosilicate HLW glasses, the MS-LAW-1 glass contains components that tend to precipitate from glass during cooling. As the glass is poured into a canister, crystallization takes place within the temperature interval between the liquidus temperature $\left(T_{L}\right)$ and the glass-transition temperature $\left(T_{g}\right)$. A portion of the glass cast into canisters is quenched on the canister walls, and another portion of glass, near the canister centerline, cools more slowly. Thus, the temperature history of the CCC glass is most favorable for crystalline phases to form. As a crystalline phase precipitates, it affects the glass matrix, in which it is embedded, both chemically and mechanically. These changes can affect the rate of glass dissolution in water and thus change its chemical durability (Kim et al. 1995; Cicero et al. 1993). The effect of CCC treatment on the PCT of HLW glasses was determined for more than 100 glass compositions (Hrma et al. 1994; Kim et al. 1995). Riley et al. (2002) indicated that the residual glass composition was the major factor that controlled the PCT response of HLW glasses with durable crystalline phases. Other chemical or mechanical factors, such as concentration gradients and mechanical stresses, played a secondary role. The response of the MS-LAW-1 CCC glass indicates that the residual glass matrix was changed but had no practical impact on the durability response in terms of acceptability.

\subsection{VHT}

The VHT results (performed at MO-SCI and PNNL) are summarized in Table 4.8. The PNNL VHT was performed only for the MS-LAW-1 glass. The results from MO-SCI and PNNL are in general reasonable agreement. The discrepancy in corrosion rate of the annealed MS-LAW-1 glass sample between MO-SCI and PNNL is attributed to a very small alteration that makes it difficult to obtain the corrosion rate accurately. There was no significant difference between the corrosion rates from the 13day and 7-day tests performed at PNNL and between 35-day and 7-day tests at MO-SCI. Optical micrographs of a cross section of the VHT samples after the 7-day tests at $200^{\circ} \mathrm{C}$ are shown in Figure 4.11. The VHT corrosion rates for all glasses for both annealed and CCC-treated samples are less than the current contract limit of $50 \mathrm{~g} / \mathrm{m}^{2}$ day (DOE 2001). Although the CCC treatment increased the VHT corrosion rate, its rate is still well below the acceptable limit, which is similar to the PCT results.

Table 4.8. VHT Corrosion Rate at $200^{\circ} \mathrm{C}$

\begin{tabular}{|c|c|c|c|c|c|c|c|c|}
\hline \multirow[b]{3}{*}{ Tests } & \multicolumn{8}{|c|}{ VHT Average Corrosion Rate (g/m $\mathbf{m}^{2}$ day) } \\
\hline & \multicolumn{2}{|c|}{ MS-LAW-1 } & \multicolumn{2}{|c|}{ MS-LAW-1-1 } & \multicolumn{2}{|c|}{ MS-LAW-1-2 } & \multicolumn{2}{|c|}{$\begin{array}{c}\text { MS-LAW-1- } \\
\text { Simplified }\end{array}$} \\
\hline & Annealed & $\mathrm{CCC}$ & Annealed & $\mathrm{CCC}$ & Annealed & CCC & Annealed & $\mathrm{CCC}$ \\
\hline MO-SCI 7-day & $<1$ & 5.0 & 5.9 & 10.1 & 6.1 & 8.2 & 8.8 & 22.3 \\
\hline MO-SCI 35-day & -- & -- & 5.7 & 6.4 & -- & -- & -- & -- \\
\hline PNNL 7-day & 3.1 & 3.5 & -- & -- & -- & -- & -- & -- \\
\hline PNNL 13-day & 3.7 & 4.4 & -- & -- & -- & -- & -- & -- \\
\hline
\end{tabular}


Annealed Glass Sample

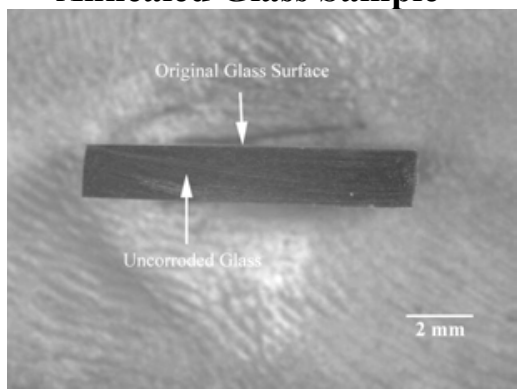

MS-LAW-1

Corrosion Rate: $<1 \mathrm{~g} / \mathrm{m}^{2} /$ day

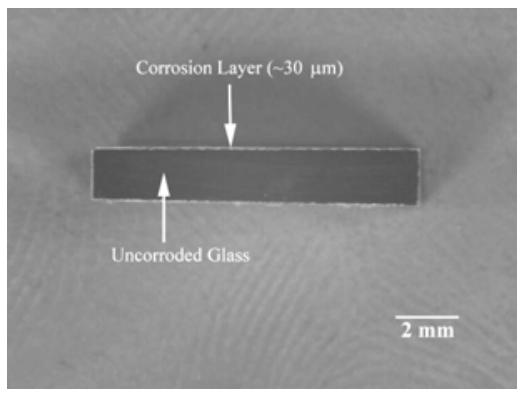

MS-LAW-1-1

Corrosion Rate: $5.9 \mathrm{~g} / \mathrm{m}^{2} / \mathrm{day}$

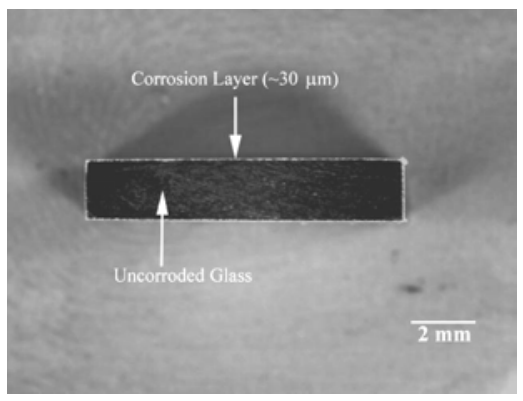

MS-LAW-1-2

Corrosion Rate: $6.1 \mathrm{~g} / \mathrm{m}^{2} / \mathrm{day}$

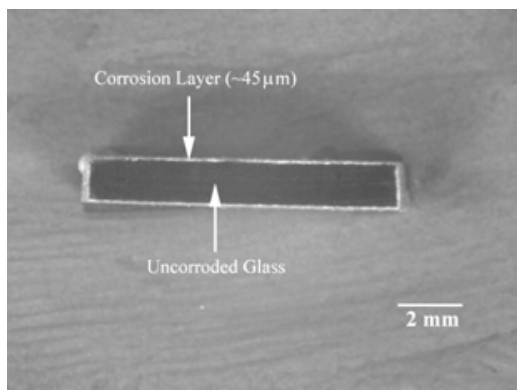

MS-LAW-1-Simplified

Corrosion Rate: $8.8 \mathrm{~g} / \mathrm{m}^{2} /$ day
Crystallized (CCC) Sample

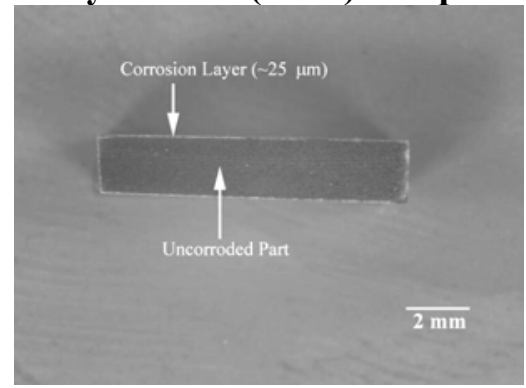

MS-LAW-1

Corrosion Rate: $5.0 \mathrm{~g} / \mathrm{m}^{2} /$ day

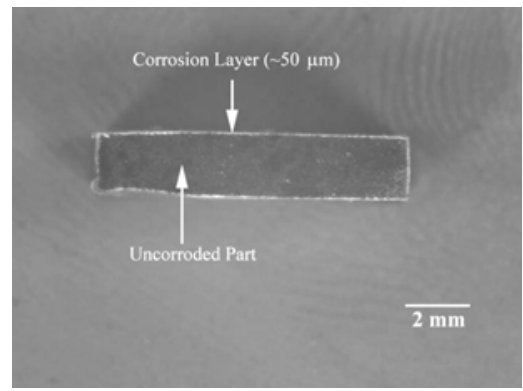

MS-LAW-1-1

Corrosion Rate: $10.1 \mathrm{~g} / \mathrm{m}^{2} / \mathrm{day}$

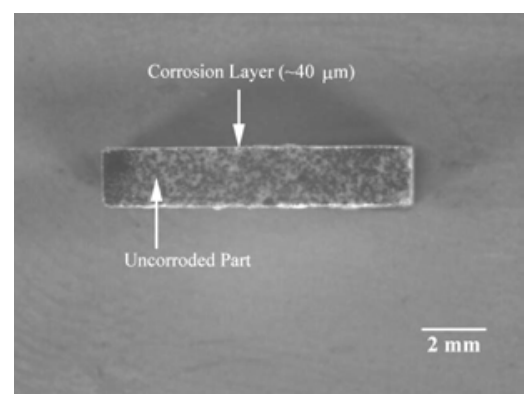

MS-LAW-1-2

Corrosion Rate: $8.2 \mathrm{~g} / \mathrm{m}^{2} /$ day

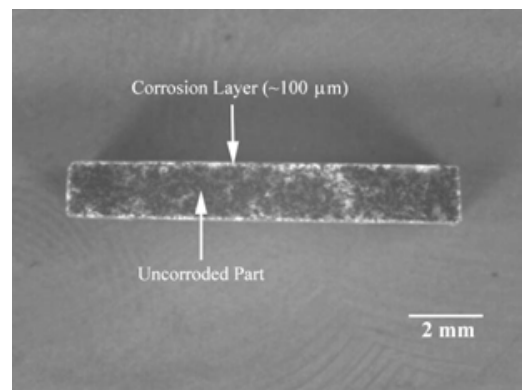

MS-LAW-1-Simplified

Corrosion Rate: $22.3 \mathrm{~g} / \mathrm{m}^{2} /$ day

Figure 4.11. Optical micrograph of the Cross Section of Glassy and Deliberately Crystallized (CCC) Iron Phosphate Waste Forms (27 wt\% LAW) after VHT at $200^{\circ} \mathrm{C}$ for 7 Days 


\subsection{CSM}

Two CSM test runs were performed in this study with the MS-LAW-1 glass composition. The first run was performed at $1150^{\circ} \mathrm{C}$ assuming that this was the intended processing temperature. However, the second run was performed at $1250^{\circ} \mathrm{C}$ to reflect the temperature used to prepare the glasses at UMR. For both test runs, there was no indication of forming a separated salt phase. This result from the present slurry-fed melting tests adds confidence to the crucible melting results that phosphate glasses with high sulfur content can be melted without forming the separated salt layer.

The present CSM tests fulfilled our primary goal of examining whether the high-sulfur-content phosphate glass feed would produce the separated salt phase under continuous-slurry-feeding conditions. One observation from the present CSM tests was that the glass that formed at the bottom of the crucible contained some clusters of unreacted materials while most of the feed was converted to glass. This may be attributed to the relatively high feed rate used in the present tests at $2.4 \mathrm{~mL} / \mathrm{min}$ compared to the typical rate of $1.3 \mathrm{~mL} / \mathrm{min}$ used in most tests with borosilicate glasses for INEEL SBW (Darab et al. 2001). This high feed rate was used based on the visual observation indicating that the feed was melting at a much faster rate than typical borosilicate glass feeds. However, the conclusion on the salt-phase formation will not be affected by the fact that a high feed rate was used because it was found from the past CSM tests with borosilicate glass feeds that the higher feed rate generated significantly more separated salt phases (Darab et al. 2001). It is also possible that the incomplete melting was caused by improper selection of raw materials for glass-forming additives as we learned the importance of raw materials on the crucible melting discussed Section 4.8. This suggests the need for more detailed study on the waste-simulant preparation, glass-composition optimization with consideration on slurry feed melting behavior, and the selection of raw materials.

\subsection{Results of One-Component-at-a-Time Variation Study}

Table 4.9 provides the target glass compositions, actual melting temperatures to prepare each glass, and analyzed compositions (in oxides). There was no indication of dependency of ratio of analyzed to target concentration of $\mathrm{P}_{2} \mathrm{O}_{5}$ and $\mathrm{Na}_{2} \mathrm{O}$ on glass composition, suggesting that there were no problems with the volatilization of major components during glass preparation. Overall, the analyzed results indicated that the targeted compositions were met except for $\mathrm{SO}_{3}$. Surprisingly, the sulfate retention (ratio of analyzed to target $\mathrm{SO}_{3}$ mass $\%$ ) ranged from 0 to $89 \%$. Because of these unexpected results, the sulfur concentrations were checked by X-ray fluorescence (XRF) analysis for selected glasses. Figure 4.12 shows that there is a good linear relation between $\mathrm{SO}_{3}$ concentrations from XRF and ICP-AES, which indicates that the results form both methods are in good agreement and support both the retention and loss of $\mathrm{SO}_{3}$ during the melting process. The difference in $\mathrm{SO}_{3}$ concentrations from XRF and ICP-AES can be attributed to the use of borosilicate glass as a reference sample in XRF analysis because reference phosphate glass was not available. 
Table 4.9. Target and Analyzed Compositions of Phosphate Glasses for One-Component Study and Melting Temperature Used to Melt the Glasses

\begin{tabular}{|c|c|c|c|c|c|c|c|c|c|c|c|c|c|c|c|c|}
\hline \multicolumn{17}{|c|}{ Target Composition (mass\%) } \\
\hline Oxide & $\begin{array}{l}\text { LAPG } \\
\text { 1-Base }\end{array}$ & $\begin{array}{l}\text { LAPG1 } \\
\text {-Al1 }\end{array}$ & $\begin{array}{l}\text { LAPG1 } \\
\text {-Al2 }\end{array}$ & $\begin{array}{l}\text { LAPG1 } \\
\text {-A13 }\end{array}$ & $\begin{array}{l}\text { LAPG1 } \\
\text {-Al4 }\end{array}$ & $\begin{array}{l}\text { LAPG1 } \\
\text {-Fe1 }\end{array}$ & $\begin{array}{l}\text { LAPG1 } \\
\text {-Fe2 }\end{array}$ & $\begin{array}{l}\text { LAPG1 } \\
\text {-Fe3 }\end{array}$ & $\begin{array}{l}\text { LAPG1 } \\
\text {-Fe4 }\end{array}$ & $\begin{array}{l}\text { LAPG1 } \\
\text {-Na1 }\end{array}$ & $\begin{array}{l}\text { LAPG1 } \\
\text {-Na2 }\end{array}$ & $\begin{array}{l}\text { LAPG1 } \\
\text {-Na3 }\end{array}$ & $\begin{array}{l}\text { LAPG1 } \\
\text {-P1 }\end{array}$ & $\begin{array}{l}\text { LAPG1 } \\
\text {-P2 }\end{array}$ & $\begin{array}{l}\text { LAPG1 } \\
\text {-P3 }\end{array}$ & $\begin{array}{l}\text { LAPG1 } \\
\text {-P4 }\end{array}$ \\
\hline $\mathrm{Al}_{2} \mathrm{O}_{3}$ & 8.51 & 2.51 & 5.51 & 11.51 & 14.51 & 9.11 & 8.81 & 8.21 & 7.91 & 8.83 & 8.19 & 7.87 & 9.97 & 9.24 & 7.78 & 7.05 \\
\hline $\mathrm{SiO}_{2}$ & 0.14 & 0.15 & 0.14 & 0.14 & 0.13 & 0.15 & 0.14 & 0.14 & 0.13 & 0.15 & 0.13 & 0.13 & 0.16 & 0.15 & 0.13 & 0.12 \\
\hline $\mathrm{Cl}$ & 0.16 & 0.17 & 0.17 & 0.15 & 0.15 & 0.17 & 0.17 & 0.15 & 0.15 & 0.17 & 0.15 & 0.15 & 0.19 & 0.17 & 0.15 & 0.13 \\
\hline $\mathrm{Cr}_{2} \mathrm{O}_{3}$ & 0.08 & 0.09 & 0.08 & 0.08 & 0.07 & 0.09 & 0.08 & 0.08 & 0.07 & 0.08 & 0.08 & 0.07 & 0.09 & 0.09 & 0.07 & 0.07 \\
\hline $\mathrm{F}$ & 0.42 & 0.45 & 0.43 & 0.41 & 0.39 & 0.45 & 0.43 & 0.41 & 0.39 & 0.44 & 0.40 & 0.39 & 0.49 & 0.46 & 0.38 & 0.35 \\
\hline $\mathrm{Fe}_{2} \mathrm{O}_{3}$ & 14.67 & 15.63 & 15.15 & 14.19 & 13.71 & 8.67 & 11.67 & 17.67 & 20.67 & 15.22 & 14.12 & 13.57 & 17.19 & 15.93 & 13.41 & 12.15 \\
\hline $\mathrm{K}_{2} \mathrm{O}$ & 0.13 & 0.14 & 0.13 & 0.13 & 0.12 & 0.14 & 0.13 & 0.13 & 0.12 & 0.13 & 0.13 & 0.12 & 0.15 & 0.14 & 0.12 & 0.11 \\
\hline $\mathrm{Na}_{2} \mathrm{O}$ & 20.00 & 21.31 & 20.66 & 19.34 & 18.69 & 21.41 & 20.70 & 19.30 & 18.59 & 17.00 & 23.00 & 26.00 & 23.43 & 21.72 & 18.28 & 16.57 \\
\hline $\mathrm{P}_{2} \mathrm{O}_{5}$ & 53.38 & 56.88 & 55.13 & 51.63 & 49.88 & 57.13 & 55.26 & 51.50 & 49.63 & 55.38 & 51.38 & 49.38 & 45.38 & 49.38 & $\mathbf{5 7 . 3 8}$ & 61.38 \\
\hline $\mathrm{SO}_{3}$ & 2.51 & 2.67 & 2.59 & 2.43 & 2.35 & 2.69 & 2.60 & 2.42 & 2.33 & 2.60 & 2.42 & 2.32 & 2.94 & 2.73 & 2.29 & 2.08 \\
\hline Sum & 100.00 & 100.00 & 100.00 & 100.00 & 100.00 & 100.00 & 100.00 & 100.00 & 100.00 & 100.00 & 100.00 & 100.00 & 100.00 & 100.00 & 100.00 & 100.00 \\
\hline \multicolumn{17}{|c|}{ Melting Temperature $\left({ }^{\circ} \mathrm{C}\right)$} \\
\hline $\mathrm{T}_{\mathrm{M}}$ & 1100 & 1050 & 1100 & 1150 & 1175 & 1100 & 1125 & 1100 & 1125 & 1275 & 1125 & 1100 & 1050 & 1075 & 1150 & 1225 \\
\hline \multicolumn{17}{|c|}{ Analyzed Composition (mass\%) } \\
\hline $\mathrm{Al}_{2} \mathrm{O}_{3}$ & 8.80 & 2.69 & 5.76 & 11.85 & 14.71 & 9.06 & 8.93 & 8.33 & 8.14 & 9.15 & 8.33 & 7.81 & 9.85 & 9.38 & 7.97 & 7.30 \\
\hline $\mathrm{SiO}_{2}$ & 0.28 & 0.21 & 0.19 & 0.16 & 0.17 & 0.17 & 0.16 & 0.15 & 0.15 & 0.25 & 0.24 & 0.25 & 0.17 & 0.17 & 0.18 & 0.27 \\
\hline $\mathrm{Cr}_{2} \mathrm{O}_{3}$ & 0.09 & 0.09 & 0.09 & 0.08 & 0.08 & 0.09 & 0.09 & 0.09 & 0.08 & 0.10 & 0.09 & 0.08 & 0.10 & 0.10 & 0.08 & 0.07 \\
\hline $\mathrm{Fe}_{2} \mathrm{O}_{3}$ & 12.40 & 13.53 & 12.99 & 12.01 & 12.19 & 7.77 & 10.60 & 15.84 & 18.79 & 13.66 & 12.58 & 11.90 & 15.03 & 14.36 & 12.32 & 11.01 \\
\hline $\mathrm{K}_{2} \mathrm{O}$ & 0.13 & 0.16 & 0.15 & 0.14 & 0.14 & 0.16 & 0.14 & 0.16 & 0.11 & 0.13 & 0.14 & 0.13 & 0.16 & 0.16 & 0.12 & 0.11 \\
\hline $\mathrm{Na}_{2} \mathrm{O}$ & 22.82 & 24.44 & 23.76 & 22.14 & 21.20 & 23.63 & 22.82 & 21.74 & 20.93 & 19.58 & 25.11 & 28.22 & 25.38 & 24.30 & 21.06 & 18.77 \\
\hline $\mathrm{P}_{2} \mathrm{O}_{5}$ & 55.13 & 58.40 & 56.45 & 52.64 & 51.52 & 58.64 & 56.81 & 52.36 & 51.06 & 57.55 & 53.23 & 49.96 & 45.43 & 50.69 & 60.00 & \begin{tabular}{|l|}
63.04 \\
\end{tabular} \\
\hline $\mathrm{SO}_{3}$ & 0.28 & 0.60 & 0.42 & 0.40 & 0.47 & 0.24 & 0.31 & 0.62 & 0.58 & 0.00 & 0.53 & 1.40 & 2.63 & 0.78 & 0.00 & 0.00 \\
\hline Sum & 99.92 & 100.11 & 99.81 & 99.42 & 100.48 & 99.76 & 99.85 & 99.28 & 99.83 & 100.40 & 100.25 & 99.75 & 98.76 & 99.94 & 101.74 & 100.57 \\
\hline
\end{tabular}




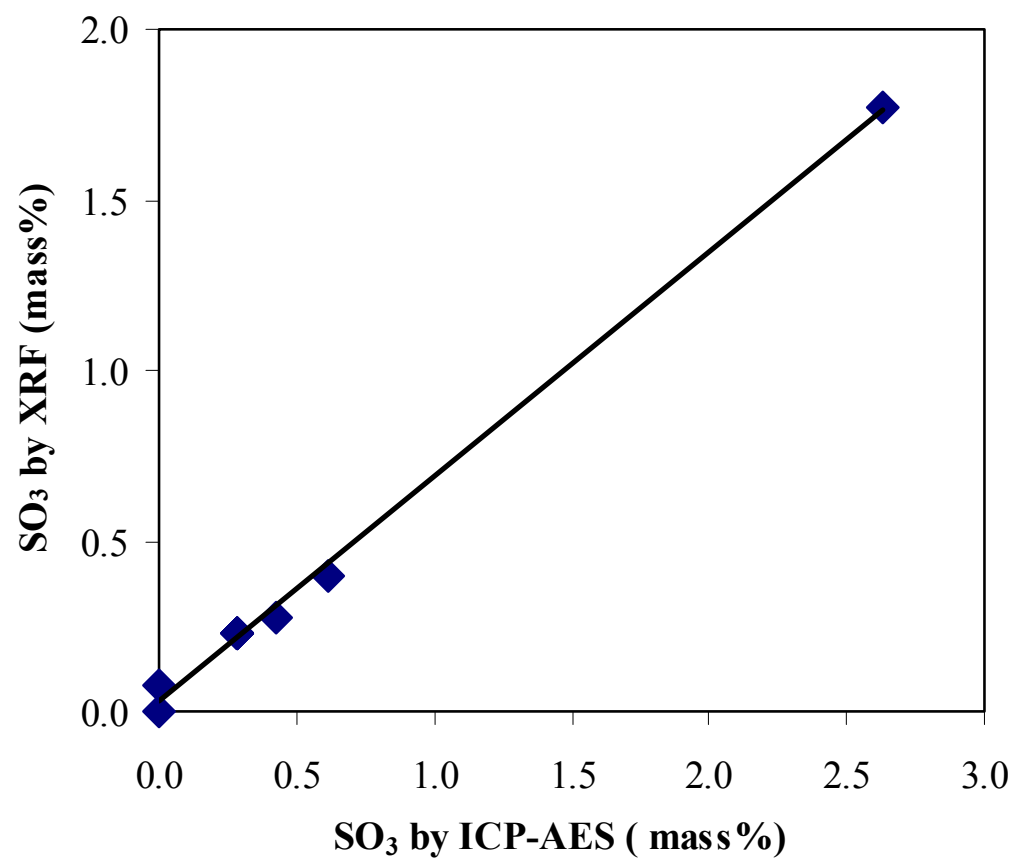

Figure 4.12. Comparison of $\mathrm{SO}_{3}$ Concentrations Obtained by XRF and ICP-AES

The effect of change of component concentration from a base glass on the $\mathrm{SO}_{3}$ retention calculated based on ICP-AES results is given in Figure 4.13. Figure 4.13 shows that $\mathrm{SO}_{3}$ retention was strongly affected by $\mathrm{P}_{2} \mathrm{O}_{5}$ and $\mathrm{Na}_{2} \mathrm{O}$ concentrations - it increased as $\mathrm{P}_{2} \mathrm{O}_{5}$ decreased and as $\mathrm{Na}_{2} \mathrm{O}$ increased. The effect of $\mathrm{Al}_{2} \mathrm{O}_{3}$ and $\mathrm{Fe}_{2} \mathrm{O}_{3}$ concentrations was relatively minor- $\mathrm{SO}_{3}$ retention increased slightly as $\mathrm{Fe}_{2} \mathrm{O}_{3}$ increased and as $\mathrm{Al}_{2} \mathrm{O}_{3}$ increased or decreased from a base glass that had a minimum retention.

It has been known that the $[\mathrm{O}] /[\mathrm{P}]$ ratio shows a good correlation with certain glass properties (Brow $2000)$ depending on properties and composition range as the $[\mathrm{O}] /[\mathrm{P}]$ ratio can often be used as the parameter relating to the glass structure. Figure 4.14 shows the effect of the $[\mathrm{O}] /[\mathrm{P}]$ ratio on the $\mathrm{SO}_{3}$ retention for the glasses tested in this study. There is a very rough general trend that the $\mathrm{SO}_{3}$ retention increases with the increasing $[\mathrm{O}] /[\mathrm{P}]$ ratio. The very weak correlation between sulfate retention and the $[\mathrm{O}] /[\mathrm{P}]$ ratio may suggest that there are factors other than glass composition and structure that affect $\mathrm{SO}_{3}$ retention even in the crucible melting conditions. The temperature and time used in glass preparation are also expected to play an important role.

The relatively high sulfate retention reported by Kim et al. (2003c) should be valid for that particular glass composition, and it should not be accepted as a universal fact that all phosphate glasses can incorporate high sulfate. The glass used by Kim et al. (2003c) had a relatively low $\mathrm{P}_{2} \mathrm{O}_{5}$ and high total alkalis, which was favorable for high sulfate retention. The results from the present study suggest the need for more detailed studies on sulfate behavior or partitioning. This is especially true considering that the fate of sulfate will also be dependent on the feed materials (e.g., dry chemicals or slurry mixed with raw chemical or pre-melted glass frit), melting temperature and time, and melting method (e.g., crucible melting and continuous slurry-fed melting). The development of glass composition should consider sulfate retention as a major property that requires optimization. 
The significance of the present results shown in Figure 4.13 is that they present the potential to obtain very high sulfate retention in phosphate glass through glass formulation. Compared to solving the sulfate separation problems by releasing sulfur through the off-gas system, the high sulfate retention will eliminate the concerns related to the sulfur collected in the off-gas system that need to be treated separately or recycled back into the melter.

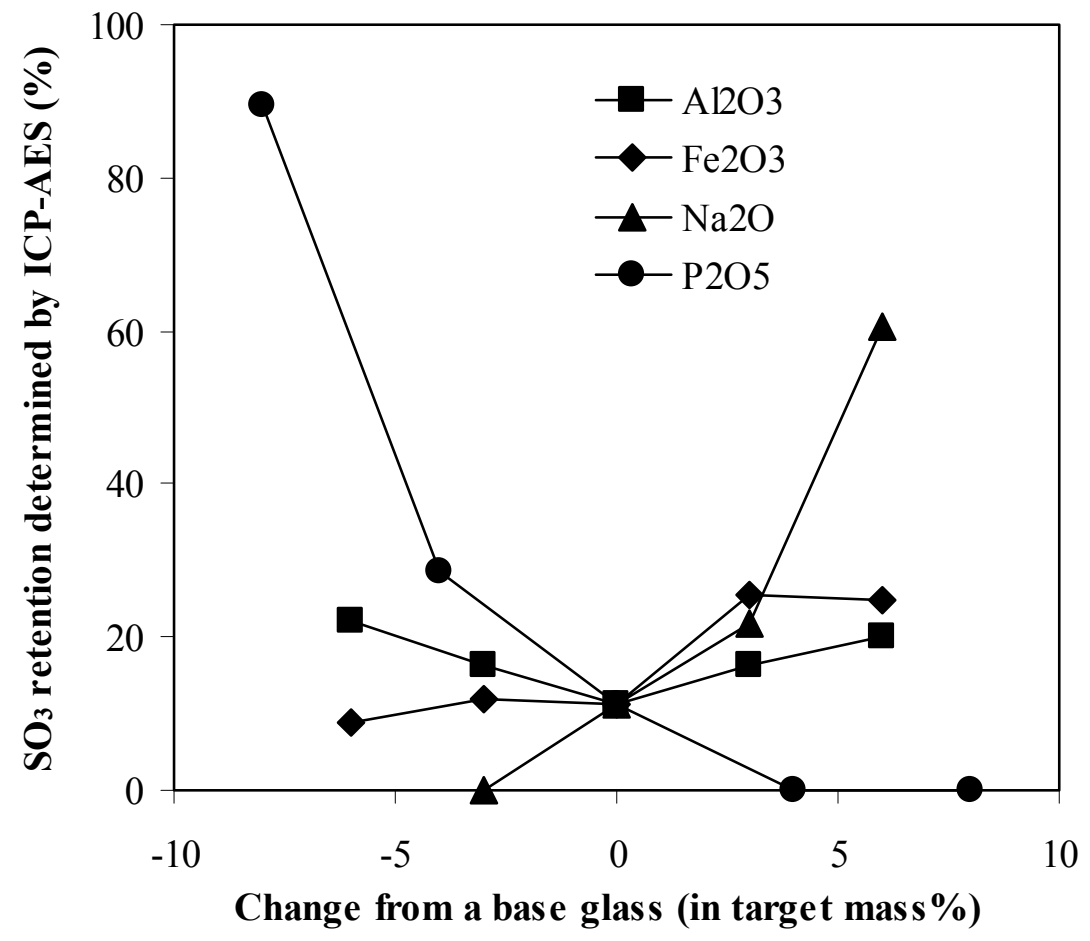

Figure 4.13. Effect of Component Concentration Change on the $\mathrm{SO}_{3}$ Retention 


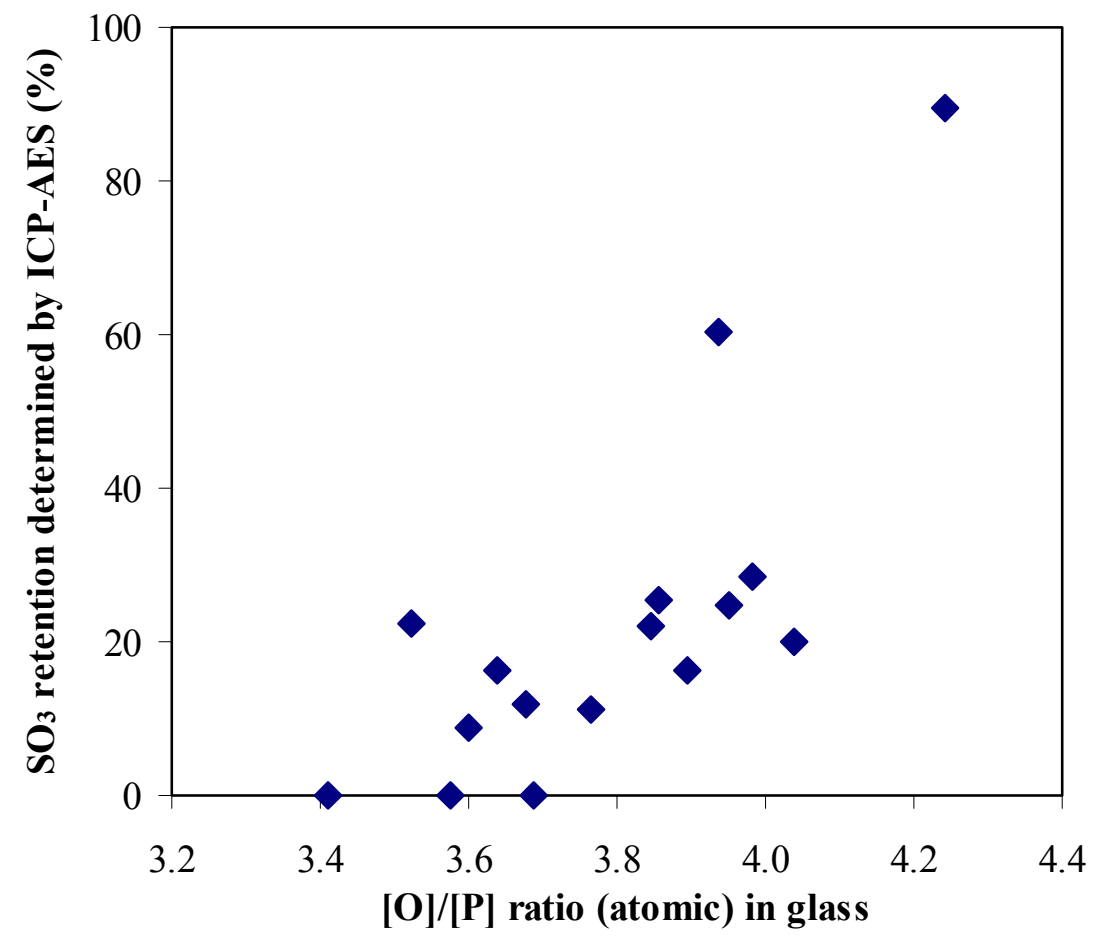

Figure 4.14. Effect of $[\mathrm{O}] /[\mathrm{P}]$ Ratio in the Glasses for One-Component-at-a-Time Variation Study on the $\mathrm{SO}_{3}$ Retention 


\subsection{Technical Uncertainties}

This section discusses the technical issues related to the application of iron phosphate glasses for HLW or LAW immobilization identified during technical research and development over the past decade. It should be mentioned that these issues should not deter or stop further research, consideration, or selection of iron phosphate glasses for immobilization purposes. The latter statement is supported by the promising results obtained for the LAW-containing iron phosphate waste forms investigated in the previous section. The issues identified may, however, be used to identify areas where technical risk could be lowered via additional development studies. A brief discussion of the technical uncertainties is summarized below in an attempt to address some of the uncertainties and/or issues identified by Perez et al. (2001) associated with iron phosphate glasses. More specifically, results have been presented with respect to the impact of crystallization on durability, technical maturity, refractory/electrode corrosion, and the interactive effects of minor components on waste loading. For those uncertainties not covered in the current work scope (due to limited funding), recommendations or insight into subsequent testing are provided in Sections 6.0 and 7.0.

\subsection{Impact of Crystallization on Durability}

Perez et al. (2001) reported that the data appear to be limited with respect to the impacts of the type and extent of crystallization on the performance of the final product. Data presented in this study (albeit limited) have demonstrated that the iron phosphate glasses containing over 20 mass $\% \mathrm{Na}_{2} \mathrm{O}$, both asmelted and CCC-treated forms, have acceptable chemical durability based on current PCT and VHT standards. As with other glasses, crystallization is more probable upon slow cooling, but the present data indicate that the impact of crystallization on durability is minimal and not of major practical concern.

Regardless of the base system (e.g., borosilicate or iron phosphate), the degree of crystallinity and the potential impacts on radiation damage, radionuclides partitioning, and accelerated grain-boundary dissolution associated with a partially crystallized waste form should be understood.

\subsection{Technical Maturity}

The United States has essentially no "pilot-scale" data on processing a phosphate-based glass with an integrated flowsheet. However, the Russians have been using an aluminum phosphate-based glass to immobilize HLW since the late $1980 \mathrm{~s}$. Over $10000 \mathrm{~m}^{3}$ of HLW with an approximate total activity of $12 \mathrm{PBq}$ (325 MCi) were vitrified, producing roughly 1740 canisters through 1995 (Aloy et al. 1996). Based on a personal communication with Dr. Albert Aloy, V.G. Khlopin Radium Institute, a new ceramic melter is currently under construction that will also process HLW using a similar aluminum phosphate glass waste form. This alumino-phosphate glass is of very similar composition to the iron phosphate glasses presented in this report with $21 \pm 3$ mass $\% \mathrm{Na}_{2} \mathrm{O}, 55 \pm 5 \% \mathrm{P}_{2} \mathrm{O}_{5}$, and $24 \pm 2 \%$ others which primarily are composed of $\mathrm{Al}_{2} \mathrm{O}_{3}$ and $\mathrm{Fe}_{2} \mathrm{O}_{3}$. The Mayak plant that produces this phosphate glass successfully uses fused cast alumina-zirconia-silica (AZS) refractories (similar to those used in the U.S. commercial glass industry) and molybdenum electrodes.

While there are no anticipated show-stoppers for the use of JHCM technology for production of ironphosphate LAW glasses, other methods of glass production may also be considered. The small-scale melting of iron phosphate glasses, ranging in size from 1 to about $20 \mathrm{~kg}$, indicates that there are several possibilities for large scale melting. Quantities approaching $25 \mathrm{~kg}$ have been successfully melted in 
commercially available refractory crucibles (aluminosilicate) in ordinary electric furnaces at MO-SCI Corp. without any significant processing issues. ${ }^{\text {(a) }}$

Induction melting, either hot or cold wall, has been of recent interest since this method eliminates the need for metal electrodes to heat the melt (thereby avoiding any potential corrosion of the metal by the melt) and, in the case of cold crucible induction melting (CCIM), refractories are not required since the melt frozen to the cold metal wall serves as its own refractory (container). Earlier 2002, two iron phosphate glasses (compositions developed at UMR) containing 40 and 48 mass $\%$ of the SBW from INEEL (a high $\mathrm{Na}_{2} \mathrm{O}+\mathrm{SO}_{3}$ waste stream), were successfully melted in a CCIM at the V. G. Klopin Radium Institute in Russia (Kim et al. 2003b). Each raw batch where phosphoric acid was used as the source of phosphate was successfully melted from a cold start and quenched to a glass. The properties of the glasses melted in the CCIM were very close to the properties of the same glass conventionally melted at UMR (Kim et al. 2003b). These encouraging results indicate that CCIM technology could be an attractive and practical method of melting iron phosphate glasses.

Preliminary hot-wall induction melting trials of iron phosphate glasses have been conducted in Japan $^{(\text {b) }}$ and at UMR, and future experiments are planned. In hot-wall induction melting, the melt is contained in a refractory container that may also function as the susceptor, or an independent susceptor is used. The melting can be continuous as a batch is continuously charged in the crucible from the top while the melt drains continuously from the bottom. Small hot-wall induction trials have been conducted at UMR also, and trials involving larger $(2 \mathrm{~kg})$ melts are planned for the near future. Hot-wall induction melting is attractive because 1) power units of the needed size and reliability are commercially available, 2) the electric field stirs the fluid melt and accelerates chemical homogenization, 3) minimum amounts of refractories are required, and 4) the overall furnace size should be smaller than conventional Joule-heated melters for the same output. The choice of refractories for maximum service life is still unknown.

Microwave melting of iron phosphate glasses is a final technology that may also be feasible based on the results being obtained from experiments in progress on small-scale (50 to $100 \mathrm{~g})$ melts. In experiments being conducted at the Energy and Nuclear Research Institute in Brazil ${ }^{(\mathrm{c})}$ in collaboration with UMR, several iron phosphate glasses have been successfully melted, starting from a cold, raw batch, in an ordinary microwave oven (1100 watts). Compositions containing significant amounts of alkalis, such as the soda in the Hanford LAW, are an advantage since this improves the coupling of the microwave energy with the melt and promotes rapid melting. Microwave melting again eliminates the need for metal electrodes in the melt, but some type of crucible is required (alumina and silica are being used in the present work). The chemical and mechanical properties of the iron phosphate glasses prepared with microwave heating are being measured, but little difference is expected between these microwave-melted glasses and those melted conventionally.

Although alternative melting technologies have been identified and are currently being evaluated, the development and demonstration of a fully integrated flowsheet is of utmost importance.

\subsection{Corrosion of Refractory Materials}

Information regarding the corrosion of refractories by iron phosphate glasses is limited at this time, and this is an area where additional work is needed. However, existing information clearly shows that iron phosphate glasses do not corrode commercial refractories to the degree normally expected for other

(a) Unpublished work, MO-SCI Corp. 2002.

(b) K. Suzuki, Institute of Research and Innovation, Kashiwa, Japan, personal communication.

(c) J.R. Martinelli, Energy \& Nucl. Res. Inst., Brazilian Nucl. Energy Comm., Sao Paulo, Brazil, personal communication. 
phosphate glasses (Chen and Day 1999). For reasons not fully understood at this time, iron phosphate melts wet ordinary refractory oxides like alumina or mullite much less than most other phosphate melts, so iron phosphate melts corrode ordinary refractories only weakly. (Chen and Day 1999). The Russian experience has shown that processing of similar iron-alumino-phosphate glasses is possible in AZS refractories with molybdenum electrodes.

Another example is the MO-SCI's experience with dense aluminosilicate crucibles that show little to no wear or corrosion by iron phosphate glasses, either below, at, or above the melt line. The crucible used for these experimental melts was a standard DFC Ceramic's a fused high-silica product having the nominal composition listed in Table 5.1. The crucibles used were cross-sectioned and examined for evidence of corrosion. No significant corrosion was evident on any of the crucibles examined. Figure 5.1 shows the cross section of a DFC crucible in which the MS-LAW-1 composition was melted for $3 \mathrm{hr}$ at $1250^{\circ} \mathrm{C}$ and then subsequently cooled for 48 -hr for the CCC heat treatment.

Table 5.1. Information on DFC Ceramics Crucible (supplied by DFC)

\begin{tabular}{|l|c|}
\hline Component & Wt\% \\
\hline $\mathrm{SiO}_{2}$ & $82.8 \%$ \\
\hline $\mathrm{Al}_{2} \mathrm{O}_{3}$ & $14.9 \%$ \\
\hline $\mathrm{Fe}_{2} \mathrm{O}_{3}$ & $0.5 \%$ \\
\hline $\mathrm{TiO}_{2}$ & $0.3 \%$ \\
\hline $\mathrm{CaO}+\mathrm{MgO}$ & $0.23 \%$ \\
\hline $\mathrm{Na}_{2} \mathrm{O}+\mathrm{K}_{2} \mathrm{O}$ & $0.8 \%$ \\
\hline Maximum Service Temp & $3000^{\circ} \mathrm{F} / 1649^{\circ} \mathrm{C}$ \\
\hline Bulk Density & $110 \mathrm{lb} / \mathrm{ft}^{3} / 1.77 \mathrm{~g} / \mathrm{cm}^{3}$ \\
\hline Apparent Porosity & $21 \%$ \\
\hline
\end{tabular}

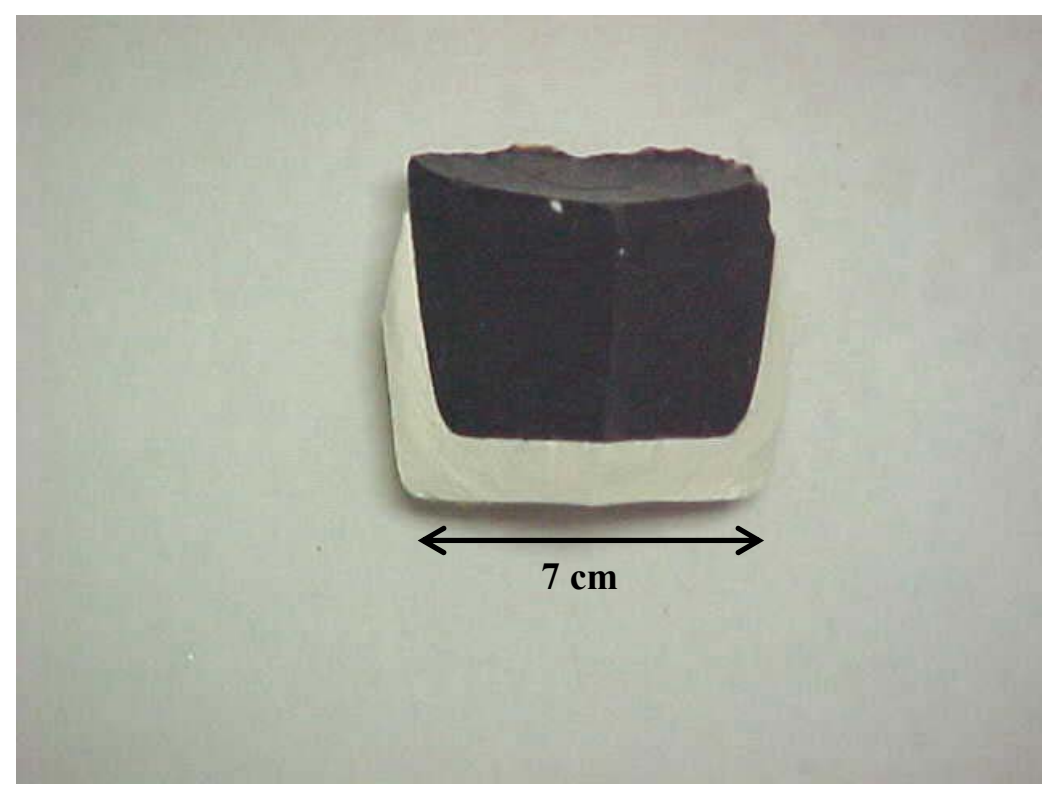

Figure 5.1. A Cross Section of a DFC Crucible in Which the MS-LAW-1 Composition Was Melted

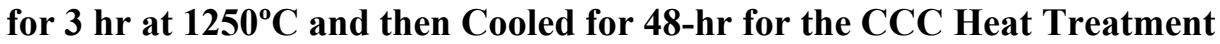

\footnotetext{
${ }^{a}$ DFC Ceramics, Inc., P.O. Box 110, 515 South 9th Street, Canon City, CO, 81215-0110.
} 
These preliminary results are encouraging since they suggest that the corrosion rate of common commercial refractories in iron phosphate melts should be comparable to their corrosion rate in borosilicate glasses such as those now being melted in the Defense Waste Processing Facility (DWPF) melter. However, alternative processing technologies, such as cold-wall induction melting, could eliminate or minimize this issue as discussed in Section 5.2.

\subsection{Corrosion of Electrodes}

The most efficient method for melting iron phosphate glasses is unknown at this time and is an area where additional research is needed. However, among the several candidate melting methods are JHCMs, microwave melting, or some type of cold (CCIM) or hot wall induction melting as discussed in Section 5.2. The extensive technology available for JHCMs is an advantage that must be balanced against the corrosion of melter refractories and metal electrodes.

Limited information is available for what type of electrodes (metals) could be used in iron phosphate melts since at this time these glasses have been melted in simple refractory crucibles in electrically heated furnaces. However, recent studies have focused on evaluating the corrosion resistance of both fully and partially submerged samples of Inconel 690 and 693. In the preliminary work now in progress, the weight loss of these two metals in an iron phosphate melt (22\% soda) containing 30 mass $\%$ of Hanford LAW (slightly different from MS-LAW-1-1 which contains 27 mass \% LAW) is being measured as a function of time at $1025^{\circ} \mathrm{C}$, the melting temperature for this composition.

The weight loss for submerged samples (cubes about $6 \mathrm{~mm}$ on an edge and weighing $5 \mathrm{~g}$ ) of these two metals is shown in Figure 5.2. The weight loss at 62 days was only 5 mass $\%$, with very little difference between the two metals.

\section{$\%$ Weight Loss of Totally Submerged Inconel 690 and 693 in Iron Phosphate Melt Containing 30 wt\% Hanford LAW @ $1025^{\circ} \mathrm{C}$}

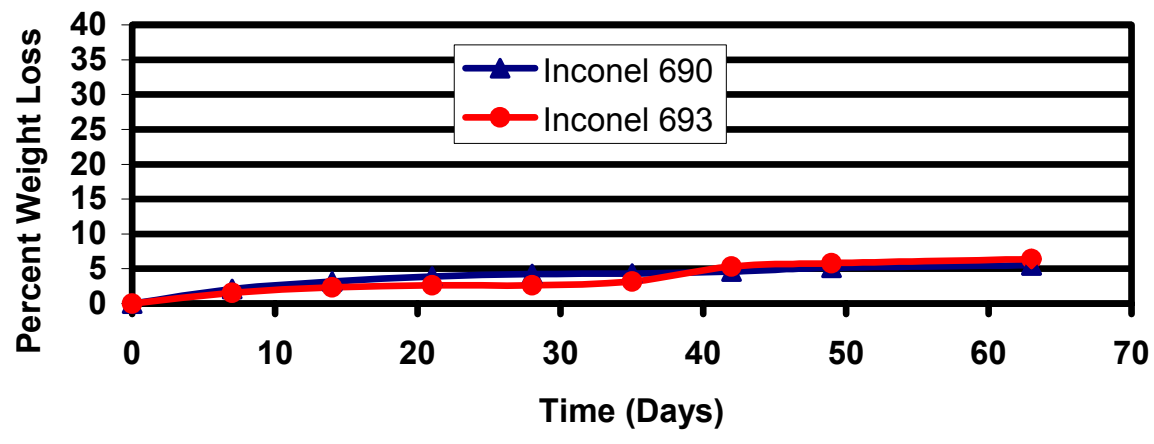

Figure 5.2. Weight Loss of Inconel 690 and 693 Samples Totally Submerged in Iron Phosphate Melt (22 mass\% soda) containing 30 mass\% of Hanford LAW Waste 
Samples of these two metals that are only partially submerged are also being investigated in the same iron phosphate melt containing Hanford LAW. Bars about $38 \mathrm{~mm}$ long and $5 \mathrm{~mm}$ square are stood on end so that the top third of the metal bar extends out of the melt. In this more severe test, the Inconel 690 was rapidly corroded at the melt line, but the Inconel 693 was much more resistant, its weight loss being only 0.3 mass $\%$ after 4 days at $1025^{\circ} \mathrm{C}$.

Based on the preliminary results, it appears that electrodes made from Inconel 693 could be a candidate for use in JHCMs. It should also be noted that molybdenum electrodes have been successfully used in joule heated melters in Russia to melt iron-alumino-phosphate glasses for long periods of time, up to six years ${ }^{\mathrm{a}}$ (JCCEM Workshop 1997). It is premature to conclude that JHCM is the best method for melting the iron phosphate compositions, but the results being obtained for Inconel 693 are encouraging. Nevertheless, iron phosphate glasses have been successfully melted (small scale) by microwave heating and by cold-crucible induction melting (CCIM) in Russia where no electrodes are needed.

\subsection{Selection of Raw Materials}

For a given glass composition choice of raw materials have significant effects on the processing of the slurry feed, such as feed rheology, feed melting rate, and volatilization and emission. Table 5.2 lists the glass-forming additives and possible raw materials required to produce the MS-LAW-1-1 glass composition developed in this study. The most convenient method of combining the majority of the GFA constituents with the Hanford LAW would be either in the form of a glass frit or using an all aqueous material. The GFA constituents marked with an "(1)" in Table 5.2 have been successfully melted as a glass frit. This glass frit combined with the appropriate silica and alumina additions could constitute the GFAs. Data from laboratory tests with dry chemicals and pilot-scale" processing of phosphate-based liquid LAW glass feeds would be required to determine the effect of raw materials on the feed processing.

\footnotetext{
a JCCEM Workshop-US/Russian Experiences on Solidification Technologies-Record of Meeting, Augusta, Georgia,
} September 4-5, 1997. 
Table 5.2. MS-LAW-1-1 Glass Forming Additives Composition

\begin{tabular}{|c|c|c|}
\hline Constituent & Wt\% & Raw Material \\
\hline $\mathrm{P}_{2} \mathrm{O}_{5}^{(\mathrm{a})}$ & 37.1 & $\mathrm{P}_{2} \mathrm{O}_{5}, \mathrm{H}_{3} \mathrm{PO}_{4}, \mathrm{NH}_{4} \mathrm{H}_{2} \mathrm{PO}_{4}^{(\mathrm{b})}$ \\
\hline $\mathrm{Al}_{2} \mathrm{O}_{3}$ & 20.5 & $\mathrm{Al}_{2} \mathrm{O}_{3}, \mathrm{Al}(\mathrm{OH})_{3}$, kaolinite: $\mathrm{Al}_{2} \mathrm{SiO}_{5}(\mathrm{OH})_{4}$ \\
\hline $\mathrm{SiO}_{2}$ & 16.8 & $\mathrm{SiO}_{2}$, kaolinite $\mathrm{Al}_{2} \mathrm{SiO}_{5}(\mathrm{OH})_{4}$ \\
\hline $\mathrm{Fe}_{2} \mathrm{O}_{3}{ }^{(\mathrm{a})}$ & 9.8 & $\mathrm{Fe}_{2} \mathrm{O}_{3}$, iron ore, iron phosphate waste ${ }^{(\mathrm{b})}$ \\
\hline $\mathrm{Cr}_{2} \mathrm{O}_{3}^{(\mathrm{a})}$ & 4.5 & $\mathrm{Cr}_{2} \mathrm{O}_{3}$, chromite: $(\mathrm{Mg} . \mathrm{Fe}) \mathrm{O}-(\mathrm{Cr}, \mathrm{Al})_{2} \mathrm{O}_{3}{ }^{(\mathrm{c})}$ \\
\hline $\mathrm{Bi}_{2} \mathrm{O}_{3}^{(a)}$ & 3.7 & $\mathrm{Bi}_{2} \mathrm{O}_{3}$ \\
\hline $\mathrm{ZrO}_{2}^{(\mathrm{a})}$ & 3.7 & $\mathrm{ZrO}_{2}, \mathrm{ZrSiO}_{4}$ \\
\hline $\mathrm{F}^{(\mathrm{a})}$ & 2.2 & $\mathrm{CaF}_{2}$ \\
\hline $\mathrm{La}_{2} \mathrm{O}_{3}^{(1)}$ & 1.6 & $\mathrm{La}_{2} \mathrm{O}_{3}$ \\
\hline
\end{tabular}

(a) Denotes GFA constituents that can be combined to form a glass frit.

(b) Phosphate chemical conversion coating processes are used by the metal fabricated products industry ( 600 companies, including automobile, heavy equipment, appliance, and fastener manufacturers) to condition metal surfaces for subsequent processes such as painting. This processing generates iron phosphate waste in the form of a sludge. Currently, minimal recycling of these wastes occurs with the majority being landfilled as a means of disposal. Previous work performed by MO-SCI Corp. has shown that these industrial iron phosphate wastes can be successfully used as raw materials to produce iron phosphate glasses. The composition of these iron phosphate sludges is nominally $\mathrm{FePO}_{4}$ with small (1 to $4 \mathrm{wt} \%$ ) amounts of $\mathrm{Na}_{2} \mathrm{O}, \mathrm{K}_{2} \mathrm{O}, \mathrm{CaO}, \mathrm{SiO}_{2}$, and $\mathrm{Al}_{2} \mathrm{O}_{3}$.

(c) An economical source of chrome oxide is chromite ore. Chromite ore is commonly used for refractories and as a colorant additive in the production of green glass bottles. The nominal composition of chromite ore (American Minerals, Inc.) is $45 \mathrm{Cr}_{2} \mathrm{O}_{3}, 25 \mathrm{FeO}, 14 \mathrm{Al}_{2} \mathrm{O}_{3}, 10 \mathrm{MgO}$, balance $\mathrm{SiO}_{2}, \mathrm{CaO}$, and trace elements (wt\%). All the components of chromite ore except $\mathrm{MgO}$ are found in the MS-LAW-1-1 waste-glass composition. 


\subsection{Conclusions and Recommendations}

In this limited study, the past research efforts on the phosphate-based glasses for immobilization of waste have been reviewed, and the technical uncertainties and data needs were discussed. Experimental studies were performed to address some of the technical issues that are important for the acceptable waste form. Some major conclusions are:

- It was demonstrated that the phosphate glasses containing over 20 mass $\% \mathrm{Na}_{2} \mathrm{O}$, both as-quenched and the CCC-treated form, has a satisfactory chemical durability based on current PCT and VHT standards. The glass becomes partially crystallized upon CCC treatment, but this has only a minor effect on its chemical durability.

- There was no indication of sulfate segregation during crucible melting with dry raw materials or during liquid-fed melting using slurry feeds prepared from simulated LAW mixed with glass-forming additives. This implies that the waste loading in the iron phosphate glasses will not be limited by the $\mathrm{SO}_{3}$ content of the waste.

- It was found that sulfate retention depends strongly on the glass composition, which suggests that it may be possible to obtain high sulfate retention through glass formulation.

- The candidate phosphate glasses posses the appropriate viscosity and electrical conductivity for melting in a conventional JHCM system and did not show any evidence of noticeable volatilization of major glass components.

- It has been demonstrated that it would be possible to develop the refractory and electrode materials best suited for phosphate glasses.

Based on the promising results obtained for the LAW-containing iron phosphate waste forms investigated in the present work, further laboratory study is recommended in the following areas:

- Optimize the glass chemical composition for the purpose of maximizing the waste loading while satisfying all the requirements in terms of the effect of selecting additive materials on sulfate retention, melting rate, and melting reactions during slurry-fed melting.

- Conduct laboratory tests to asses the corrosion resistance of various refractory and electrode materials to identify the materials with optimum service performance.

- Conduct expanded durability testing on optimized waste-form compositions to include Toxicity Characteristic Leach Procedure (TCLP) tests, Pressurized Unsaturated Flow (PUF) tests, and longer term VHT and PCT tests. Investigate the formation of the chemically protective layers that have been found to form on many of the iron phosphate waste forms.

- Conduct studies on the partitioning, if any, of radioactive components in partly crystallized glasses and its effect on the release of radionuclides. 


\subsection{Additional Study Requirements}

This section identifies additional long-term needs that should be addressed before implementing iron phosphate glass in LAW immobilization efforts.

\subsection{Qualified Glass Composition Region}

Product qualification: An assessment or review of the current ILAW requirements would be required to determine if the specifications are applicable to iron phosphate glasses. For example, with respect to PCT, the current specifications stipulate that the normalized release of sodium, silicon, and boron shall be less than $2 \mathrm{~g} / \mathrm{m}^{2}$ using a 7-day test at $90^{\circ} \mathrm{C}$ (DOE 2001). If the iron phosphate waste form is deemed feasible, a review and perhaps a recommended change in the specific elements to evaluate may be required. Also included in this technical area is the initiation or opening of the lines of communication with the performance-assessment team to identify any additional data needs to support that effort.

Glass property-composition relationships: Glass property-composition models are essential to glass formulation to develop the optimized LAW glass composition for each waste stream to minimize the waste-form volume and hence reduce the cost of vitrification. The same models are also needed for product qualification of the waste form and process control for plant operation - ultimately providing the technical basis to show compliance with the waste-form specifications. The required glass properties include PCT response, viscosity and electrical conductivity as a function of temperature, liquidus temperature, TCLP response, and VHT response. Compared to borosilicate glass, the glass-property data for phosphate glasses are very limited. The composition region of the glasses for property models should be selected to cover the variations from additives used to improve the responses of the glasses to various leaching procedures and to control the process properties.

\subsection{Design Data Development}

Data must be developed to provide the technical basis for plant design. These data would be required to assure that unit operations are compatible with the iron phosphate systems and, if not, recommend alternative processes or modifications. For example, sulfur retention is a key uncertainty for the iron phosphate glasses. For a given glass composition, the fate of sulfur is strongly dependent on feed makeup and other melter-operation conditions such as melting temperature, plenum temperature, and atmosphere. It is important to obtain the information on sulfur partitioning in the conditions that closely simulate the actual melter conditions using the simulated slurry feed in the research-scale melter and/or the pilot-scale melter.

\subsection{Melter Design and Demonstration}

As mentioned in Section 5.2, the United States has essentially no "pilot-scale" data on processing DOE wastes using a phosphate-based glass with an integrated flowsheet. A suitably modified JHCM will need to be designed and constructed. This will require several stages of development and testing: 1) materials compatibility tests, 2) small scale melter design, construction and testing, 3) larger scale melter design, construction and testing, and 4) full scale melter design and construction. The larger scale melter testing will included data collection for plant operation. 


\subsection{References}

Aloy AS, VA Bel'yukov, AV Demin, and YA Revenko. 1996. "Experiences with Vitrification of HLW and Development of New Approaches in Russia." In Glass as a Waste Form and Vitrification Technology: Summary of an International Workshop, pp. E.50-E.51. National Academy Press, Washington, D.C.

American Society for Testing and Materials (ASTM). 1995. "Standard Practices for Measurement of Liquidus Temperature of Glass by the Gradient Furnace Method," C 829-81.

American Society for Testing and Materials (ASTM). 1998. "Standard Test Methods for Determining Chemical Durability of Nuclear, Hazardous, and Mixed Waste Glasses: The Product Consistency Test (PCT)," C 1285-97. In 1998 Annual Book of ASTM Standards Vol. 12.01, ASTM, West Conshohocken, PA.

Brow RK. 2000. "Review: The Structure of Simple Phosphate Glasses.” J. Non-Cryst. Solids 263 \& 264:1-28.

Chen F and DE Day. 1999. "Corrosion of Selected Refractories by Iron Phosphate Melts." In Environmental Issues and Waste Management Technologies IV; Ceramic Transaction, Vol. 93, pp. 213220. The American Ceramic Society, Westerville, $\mathrm{OH}$.

Cicero CA, SL Mara, and MK Andrews. 1993. Phase Stability Determinations of DWPF Waste Glasses $(U)$. WSRC-TR-93-227, Westinghouse Savannah River Company, Aiken, SC.

Darab JG, DD Graham, BD MacIsaac, RL Russell, DK Peeler, HD Smith, and JD Vienna. 2001. Sulfur Partitioning During Vitrification of INEEL Sodium Bearing Waste: Status Report. PNNL-13588, Pacific Northwest National Laboratory, Richland, WA.

Gan H, and IL Pegg. 2001a. Development of Property-Composition Models for RPP-WTP HLW Glasses. VSL-01R3600-1, Vitreous State Laboratory, The Catholic University of America, Washington, D.C.

Gan H, and IL Pegg. 2001b. Development of Property-Composition Models for RPP-WTP LAW Glasses. VSL-01R6600-1, Vitreous State Laboratory, The Catholic University of America, Washington, D.C.

Hrma P, GF Piepel, MJ Schweiger, DE Smith, D-S Kim, PE Redgate, JD Vienna, CA LoPresti, DB Simpson, DK Peeler, and MH Langowski. 1994. Property/Composition Relationships for Hanford HighLevel Waste Glasses Melting at $1150^{\circ} \mathrm{C}$. PNL-10359, Vol. 1 and 2, Pacific Northwest Laboratory, Richland, WA.

Huang W, CW Kim, CS Ray, and DE Day. 2003. "Solubility of High Chrome Nuclear Wastes in Iron Phosphate Glasses." Ceramic Trans. (in press).

Jantzen CM, NE Bibler, DC Beam, CL Crawford, MA Pickett. 1993. Characterization of the Defense waste Processing Facility (DWPF) Environmental Assessment (EA) Glass Standard Reference Material. WSRC-TR-92-346, Rev. 1. Westinghouse Savannah River Company, Aiken, SC.

Kim CW, D Zhu, DE Day, and D Gombert. 2003a. "Iron Phosphate glasses for Vitrifying Sodium Bearing Waste." Ceramic Trans. (in press). 
Kim CW, CS Ray, D Zhu, DE Day, D Gombert, A Aloy, A Moguš-Milanković, and M Karabulut. 2003b. "Chemically Durable Iron Phosphate Glasses for Vitrifying Sodium Bearing Waste (SBW) Using Conventional and Cold Crucible Induction Melting (CCIM) Techniques." Journal of Nuclear Materials (submitted).

Kim D-S, DK Peeler, and P Hrma. 1995. "Effects of Crystallization on the Chemical Durability of Nuclear Waste Glasses," Ceram. Trans. 61:177-185.

Kim D-S, JD Vienna, and P Hrma. 2003c. "Phosphate Glasses for Vitrification of Wastes with High Sulfur Content," Ceram. Trans. (in press).

Kirkbride RA. 2000. Tank Farm Contractor Operation and Utilization Plan (TWRS-OUP). HNF-SDWM-SP-012, Rev. 2, CH2M Hill Hanford Group, Inc., Richland, WA.

Marasinghe GK, M Karabulut, CS Ray, DE Day, DK Shuh, PG Allen, et al. 2000. "Properties and Structure of Vitrified Iron Phosphate Nuclear Wasteforms." J. Non-Cryst. Solids 263 \& 264:146-54.

Marasinghe GK, M Karabulut, X Fang, CS Ray, and DE Day. 2001. "Iron Phosphate Glasses: An Alternative to Borosilicate Glasses for Vitrifying Certain Nuclear Wastes." Ceramic Transactions, Environmental Issues \& Waste Management Technologies VI 361-68.

Muller IS, AC Buechele, and IL Pegg. 2001. Glass Formulation and Testing with RPP-WTP LAW Simulants - Final Report. VSL-01R3560-2, Vitreous State Laboratory, The Catholic University of America, Washington D.C.

Perez Jr, JM, DF Bickford, DE Day, D-S Kim, SL Lambert, SL Marra, DK Peeler, DM Strachan, MB Triplett, JD Vienna, and RS Wittman. 2001. High-Level Waste Melter Study Report. PNNL-13582, Pacific Northwest National Laboratory, Richland, WA.

Riley BJ, PR Hrma, J Rosario, and JD Vienna. 2002. "Effect of Crystallization on HLW Glass Corrosion," Ceram. Trans. 132:257-265.

Scholtze H. 1990. Glass Nature, Structure, and Properties. Springer, NY.

Smith GL, LR Greenwood, GF Piepel, MJ Schweiger, HD Smith, MW Urie, and JJ Wagner. 2000. Vitrification and Product Testing of AW-101 and AN-107 Pretreated Waste. PNNL-13372, Pacific Northwest National Laboratory, Richland, WA.

U.S. Department of Energy (DOE). 1996. Waste Acceptance System Requirements Document (WA$S R D)$. DOE/RW-0351P, U.S. Department of Energy, Office of Civilian Radioactive Waste Management, Washington D.C.

U.S. Department of Energy (DOE). 2001. Design, Construction, and Commissioning of the Hanford Tank Waste Treatment and Immobilization Plant, DOE Office of River Protection, Richland, WA; Contract with Bechtel National, Inc., San Francisco, CA, Contract No.: DE-AC27-01RV14136.

Vienna JD, WC Buchmiller, JV Crum, DD Graham, D-S. Kim, BD MacIsaac, MJ Schweiger, DK Peeler, TB Edwards, IA Reamer, and RJ Workman. 2002a. Glass Formulation Development for INEEL SodiumBearing Waste. PNNL-14050, Pacific Northwest National Laboratory, Richland, WA. 
Vienna JD, D-S Kim, and P Hrma. 2002b. Database and Interim Glass Property Models for Hanford HLW and LAW Glasses. PNNL-14060, Pacific Northwest National Laboratory, Richland, WA.

\section{Chronological List of Papers Published by University of Missouri-Rolla for the Past Decade:}

1. A Mogus-Milankovic and DE Day. 1993. "Thermally Stimulated Polarization and DC Conduction in Iron Phosphate Glasses." J. Non-Crystalline Solids 162:275-86.

2. X Yu and DE Day. 1995. "Effect of Raw Materials on the Redox State of Iron and Properties of Iron Phosphate Glasses." In Proceedings 17th IntI. Congress on Glass, Beijing, Vol. 2, 45-51.

3. A Mogus-Milankovic, DE Day, GJ Long, and GK Marasinghe. 1996. "Structuaral and Magnetic Properties of $\mathrm{Fe}_{2} \mathrm{O}_{3}-\mathrm{P}_{2} \mathrm{O}_{5}-\mathrm{Na}_{2} \mathrm{O}$ Glass." Phys. Chem. Glasses 37(2):57-61.

4. TF Meaker, WG Ramsey, JM Pareizs, DG Karraker, and DE Day. 1996. "Composition Development for Vitreous Plutonium Products." Ceram. Trans. 72:409-417.

5. X Yu, DE Day, GJ Long, and RK Brow. 1997. "Properties and Structure of Sodium-Iron Phosphate Glasses." J. Non-Crystalline Solids 215:21-31.

6. A Mogus-Milankovic, B Pivac, K Furic, and DE Day. 1997. "Structural Study of Iron Phosphate Glasses." Phys. Chem. Glasses 38(2):74-78.

7. A. Mogus-Milankovic, K Furic, CS Ray, W Huang, and DE Day. 1997. "Raman Studies of PbO$\mathrm{Bi}_{2} \mathrm{O}_{3}-\mathrm{Ga}_{2} \mathrm{O}_{3}$ Glasses and Crystallized Compositions," Phys. Chem. Glasses 38(3):148-55.

8. GK Marasinghe, M Karabulut, CS Ray, DE Day, et al. 1997. "Structural Features of Iron Phosphate Glasses," J. Non-Crystalline Solids 222:144-52.

9. A Mogus-Milankovic, M Fajiic, A Drasner, R Tojiko, and DE Day. 1998. "Crystallization of Iron Phosphate Glasses." Physics \& Chem. of Glasses 39(2):70-75.

10. GK Marasinghe, M Karabulut, CS Ray, DE Day, et al. 1998. "Redox Characteristics and Structural Properties of Iron Phosphate Glasses: A Potential Host Matrix for Vitrifying High Level Nuclear Waste." Environmental Issues and Waste Management Technologies III, Ceramic Trans. 87:261270.

11. B Pivac, A Mogus-Milankovic, and DE Day. 1998. "Iron Valence and Coordination in Phosphate Glasses as Studied by Optical Spectroscopy." J. Non-Crystalline Solids 226:41-46.

12. M Mesko, DE Day, and BC Bunker. 1998. "Immobilization of High-Level Radioactive Sludges in Iron Phosphate Glasses." Science and Technology for Disposal of Radioactive Tank Wastes. Eds. WW Schulz, and NJ Lombardo, Plenum Publishing Corp., 379-90.

13. E Day, Z Wu, CS Ray, and P Hrma. 1998. "Chemically Durable Iron Phosphate Glass Wasteforms." J. Non-Cryst. Solids 241:1-12.

14. F Chen, and D Day. 1999. "Corrosion of Selected Refractories by Iron Phosphate Melts." Ceram. Trans. 93:213-220. 
15. R Ray, X Fang, M Karabulut, G Marasinghe, and DE Day. 1999. "Iron Redox and Crystallization of Iron Phosphate Glass." Ceram. Trans. 43:187-194.

16. GK Marasinghe, M Karabulut, CS Ray, DE Day, et al. 1999. "Effects of Nuclear Waste Components on Redox Equilibria, Structural Features, and Crystallization Characteristics of Iron Phosphate Glass," Ceram. Trans. 93:195-202.

17. A Mogus-Milankovic, DE Day, and B Santic. 1999. "DC Conductivity and Polarization in Iron Phosphate Glasses.” Phys. Chem. Glasses 40 (2):69-74.

18. MG Mesko, and DE Day. 1999. "Immobilization of Spent Nuclear Fuel in Iron Phosphate Glass," $J$. Nuclear Matls. 273:27-36.

19. S Ray, X Fang, M Karabulut, GK Marasinghe, and DE Day. 1999. "Effect of Melting Temperature and Time on Iron Valence and Crystallization of Iron Phosphate Glasses." J. Non-Cryst. Solids 249:1-16.

20. M Karabulut, G Marasinghe, CS Ray, DE Day, O Ozturk, and GD Waddill. 1999. "X-ray Photoelectron and Mossbauer Spectroscopic Studies of Iron Phosphate Glasses Containing U, Cs and Bi." Non-Cryst. Solids 249:106-116.

21. A Mogus-Milankovic, B Santic, B Pivac, and DE Day. 1999. "TSC and de Conductivity for Cesium Iron Phosphate Glasses.” Phys. Chem. Glasses 40(6):305-10.

22. Y Badyal, M Karabulut, K Marasinghe, DE Day, and CS Ray. 1999. "The Effects of Uranium Oxide High-Level Waste on the Structure of Iron Phosphate Glasses." Materials Research Soc. Sym. Vol 556, Scientific Bases for Nuclear Waste Management XXII, 297-303.

23. M Mesko, DE Day, and BC Bunker. 2000. "Immobilization of $\mathrm{CsCI}$ and $\mathrm{SrF}_{2}$ in Iron Phosphate Glass." Waste Management 20:271-78.

24. M Topic, A Mogus-Milankovic, and DE Day. "A Study of Electrical Polarization Mechanisms in Sodium Iron Phosphate Glasses by Partial Thermally Stimulated Depolarization Current." J. NonCryst. Solids 261:146-54.

25. GK Marasinghe, M Karabulut, CS Ray, DE Day, DK Shuh, PG Allen, et al. 2000. "Properties and Structure of Vitrified Iron Phosphate Nuclear Wasteforms." J. Non-Cryst. Solids 263 \& 264:146-54.

26. GK Marasinghe, M Karabulut, X Fang, CS Ray, DE Day, et al. 2000. "Vitrified Iron Phosphate Nuclear Wasteforms Containing Multiple Waste Components." Transactions, American Ceramic Soc. 107:115-22.

27. M Karabulut, GK Marasinghe, CS Ray, GD Waddill, DE Day, et al. 2000. "A High Energy X-ray and Neutron Scattering Study of Iron Phosphate Glasses Containing Uranium." J. Appl. Phys. 87(5):285-93.

28. X Fang, CS Ray, GK Marasinghe, and DE Day. 2000. "Properties of Mixed $\mathrm{Na}_{2} \mathrm{O} \& \mathrm{~K}_{2} \mathrm{O}$ Iron Phosphate Glasses," J. Non-Cryst. Solids 263 \& 264:293-98.

29. A Mogus-Milankovic, B Santic, CS Ray, and DE Day. 2000. "Electrical Relaxation in Mixed Alkali Iron Pyrophosphate Glasses.” J. Non-Cryst. Solids 263 \& 264:299-304. 
30. X Fang, CS Ray, GK Marasinghe. and DE Day. 2000. "Properties of Mixed Na-K Iron Phosphate Glasses." Ceramic Transactions, Vol 107, Environmental Issues and Waste Management Technologies V, 207-14.

31. M Karabulut, GK Marasinghe, CS Ray, DE Day, et al. 2000. "Local Environment of Iron and Uranium Ions in Vitrified Iron Phosphate Glasses Studied by FeK and UL $\mathrm{LIII}_{\text {II }}$ edge X-ray Absorption Fine Structure Spectroscopy." J. Materials Res. 15(9):1972-84.

32. X Fang, CS Ray, A Mogus-Milankovic, and DE Day. 2001. "Iron Redox Equilibrium, Structure, and Properties of Iron Phosphate Glasses.” J. Non-Cryst. Solids 283(1-3):162-72.

33. A Mogus-Milankovic, B Santic, DE Day, and C. S. Ray. 2001. "Electrical Conductivity in Mixed Alkali Iron Phosphate Glasses.” J. Non-Cryst. Solids 283(1-3):119-28.

34. GK Marasinghe, M Karabulut, X Fang, CS Ray, and DE Day. 2001. "Iron Phosphate Glasses: An Alternative to Borosilicate Glasses for Vitrifying Certain Nuclear Wastes." Ceramic Transactions, Environmental Issues \& Waste Management Technologies VI 361-68.

35. M Karabulut, E Melnik, R Stefan, GK Marasinghe, CS Ray, CR Kurkjian, and DE Day. 2001. "Mechanical \& Structural Properties of Phosphate Glasses." J. Non-Cryst. Solids 288:8-17.

36. ST Reis, M Karabulut, and DE Day. 2001. "Chemical Durability \& Structure of Zinc-Iron Phosphate Glasses.” J. Non Cryst. Solids 292:150-57.

37. A Mogus-Milankovic, A Gajovic, A Santic, and DE Day. 2001. "Structure of Sodium Phosphate Glasses Containing $\mathrm{Al}_{2} \mathrm{O}_{3}$ and/or $\mathrm{Fe}_{2} \mathrm{O}_{3}$, Part I," J. Non. Cryst. Solids 289, 204-13.

38. A Mogus-Milankovic, A Santic, A Gajovic, and DE Day. 2001. "Electrical Properties of Sodium Phosphate Glasses Containing $\mathrm{Al}_{2} \mathrm{O}_{3}$ and/or $\mathrm{Fe}_{2} \mathrm{O}_{3}$, Part II." J. Non. Cryst. Solids 296:57-64.

39. A Santic, A Mogus-Milankovic, and DE Day. 2001. "The d.c. Electrical Conductivity of Iron Phosphate Glasses.” J. Non-Cryst. Solids 296:65-73.

40. F Chen, W Jie, and DE Day. 2001. "Electrical Property \& Redox State in Iron Phosphate Melts." J. Chin. Ceramic. Soc 29(1):26-30.

41. D Gombert, J Richardson, A Aloy, and DE Day. "Cold-Crucible Design Parameters for Next Generation HLW Matters." Waste Management (WM) 02 Conference, Feb. 2002, Tucson, AZ (in press).

42. ST Reis, DLA Farica, JR Martinelli, WM Pontuschka, DE Day, and CSM Partitu. 2002. "Structural Features of Lead Iron Phosphate Glasses.” J. Non. Cryst. Solids 304 1-3:188-194.

43. F Chen, W Jie, and DE Day. 2002. "Electrical Resistivity of Iron Phosphate Glasses.” Phys. and Chemistry of Glasses 43(3):133-36.

44. M Karabulut, GK Marasinghe, CS Ray, DE Day, et al. "Investigation of Iron Local Environment in Iron Phosphate Glasses with Different Fe (II) Concentration.” J. Non. Cryst. Solids (in press). 
45. ST Reis, DE Day, and M Karabulut. "Chemical Durability of Lead Iron Pyrophosphate Nuclear Waste Forms (I).” J. Non. Cryst. Solids (in press).

46. CW Kim, D Zhu, DE Day, and D Gombert. "Iron Phosphate glasses for Vitrifying Sodium Bearing Waste", Ceramic Transactions (2002), Amer. Ceramic Soc. (in press).

47. W Huang, CW Kim, CS Ray, and DE Day. "Solubility of High Chrome Nuclear Wastes in Iron Phosphate Glasses.” Ceramic Transactions (2002), Amer. Ceramic Soc. (in press). 
Appendix A DTA Curves 


\section{Appendix A: DTA Curves}

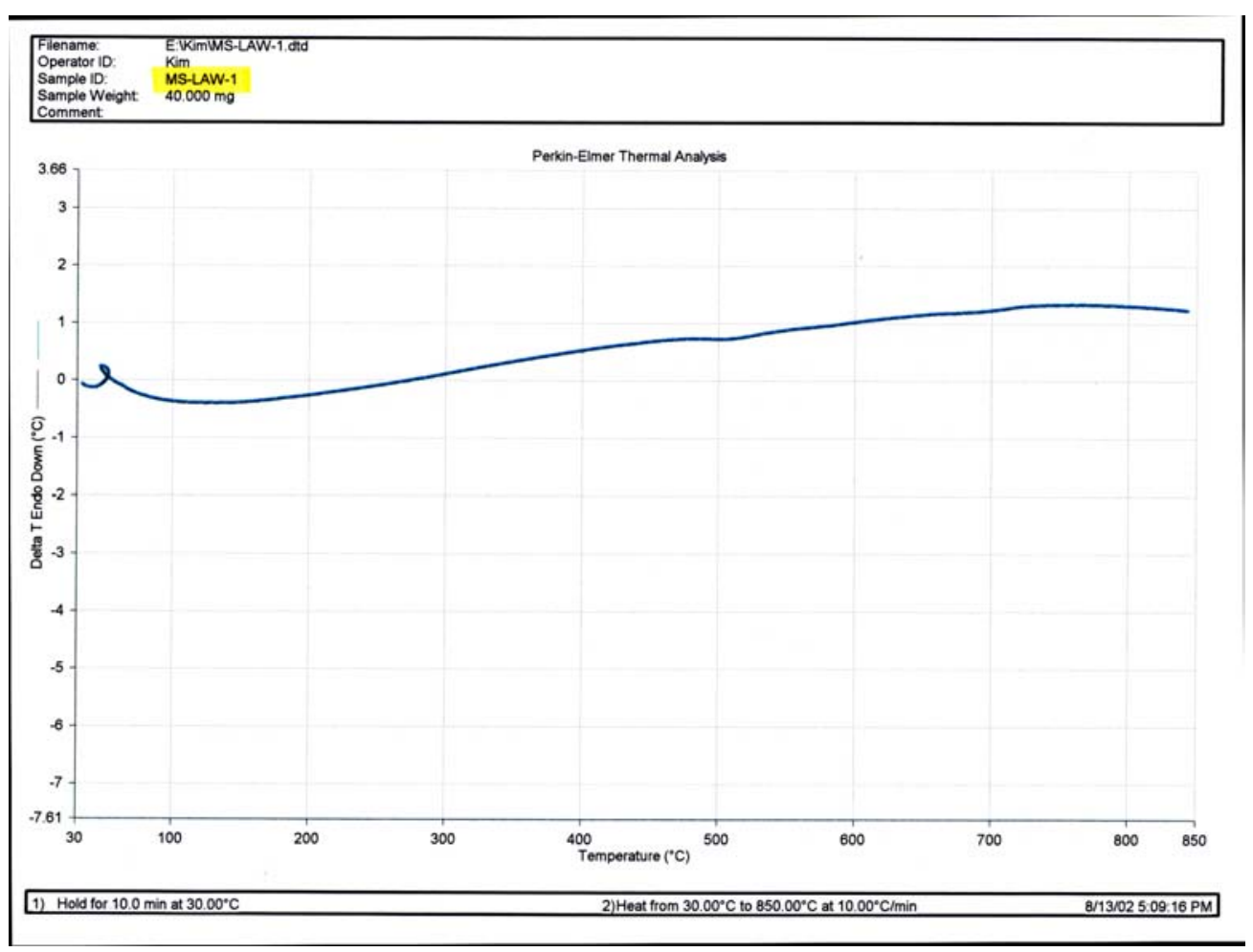

Figure A-1. MS-LAW-1 DTA Curve, Glassy Sample, Heated in Flowing Nitrogen at $10^{\circ} \mathrm{C} / \mathrm{min}$

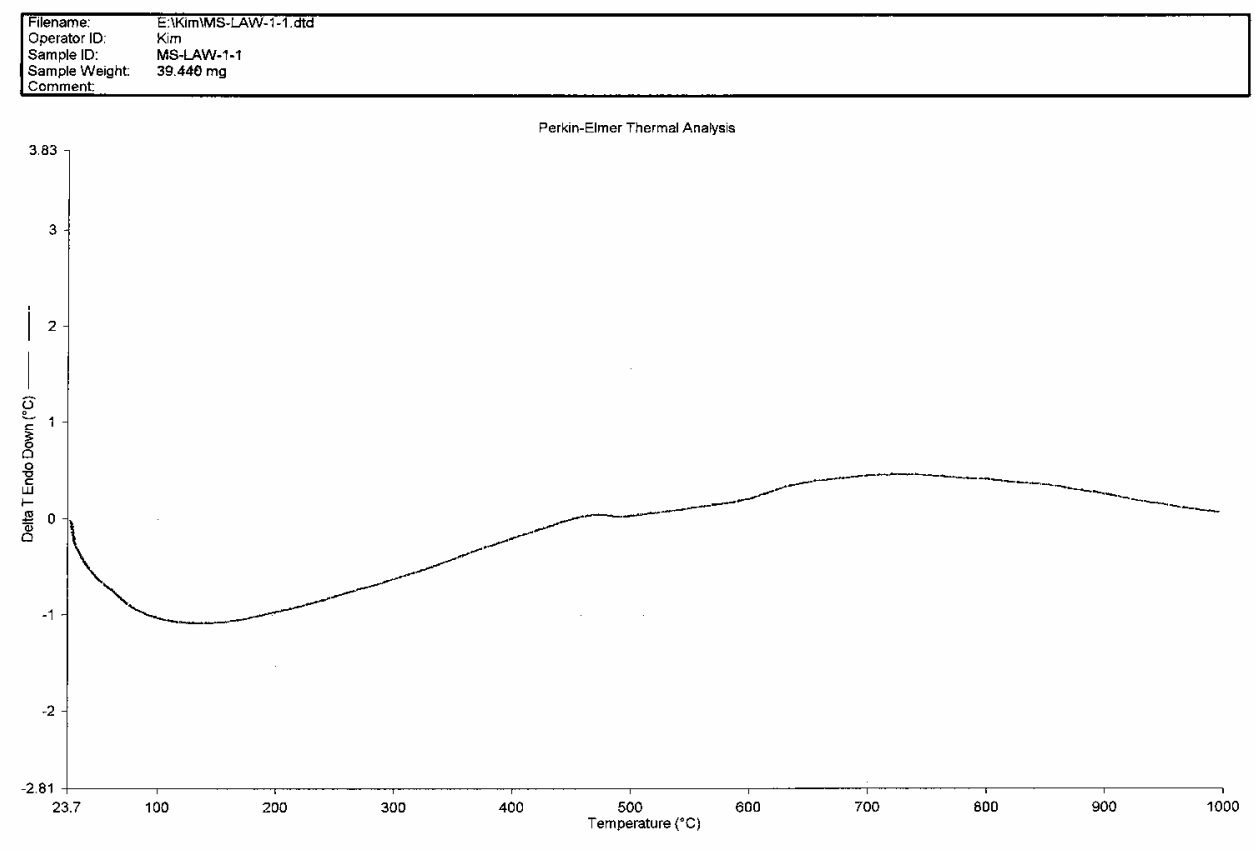

1) Hold for $10.0 \mathrm{~min}$ at $30.00^{\circ} \mathrm{C}$

2) Heat from $30.00^{\circ} \mathrm{C}$ to $1000.00^{\circ} \mathrm{C}$ at $10.00^{\circ} \mathrm{C} / \mathrm{min}$ 9/9/02 4:40:36 PM

Figure A-2. MS-LAW-1-1 DTA Curve, Glassy Sample, Heated in Flowing Nitrogen at $10^{\circ} \mathrm{C} / \mathrm{min}$ 


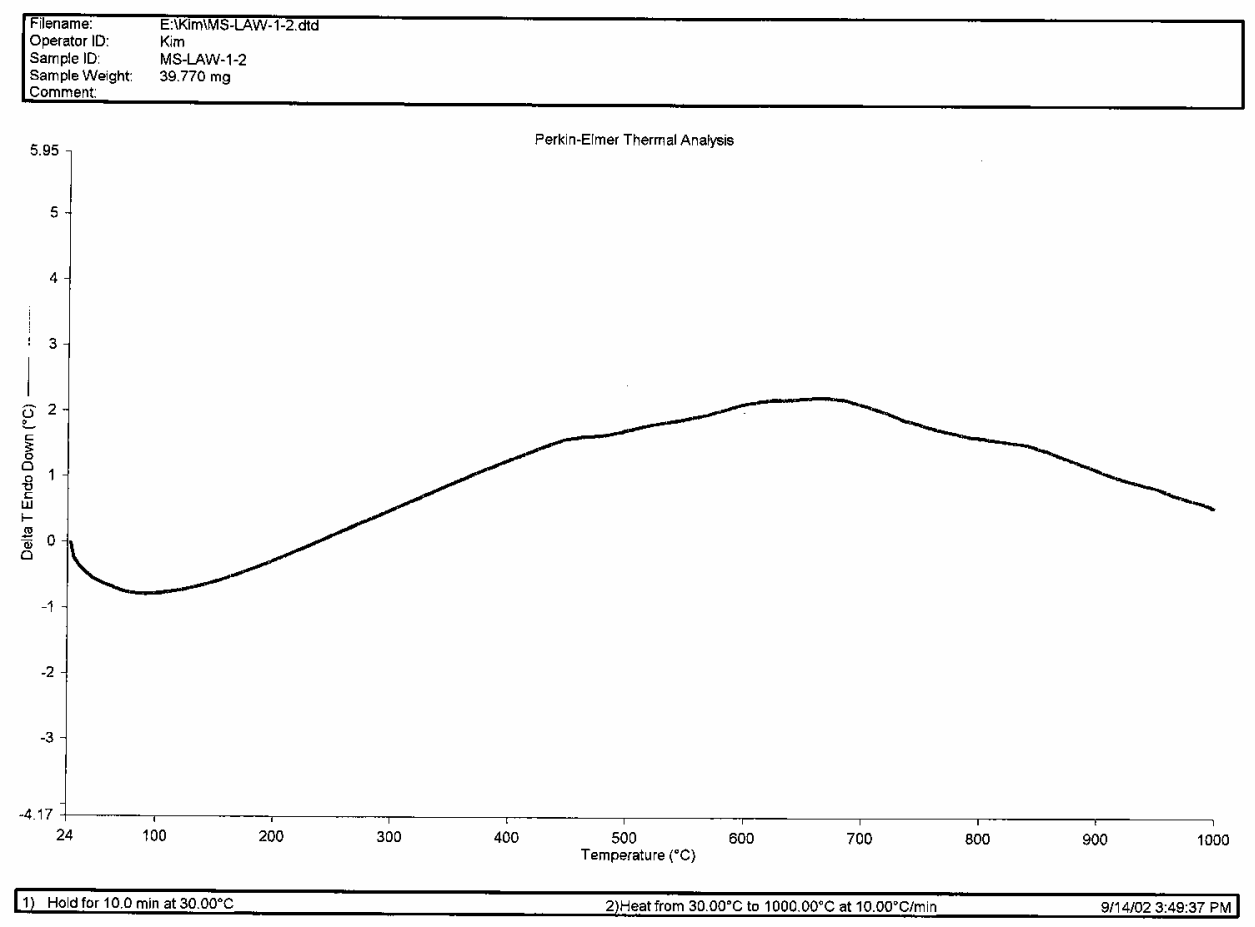

Figure A-3. MS-LAW-1-2 DTA Curve, Glassy Sample, Heated in Flowing Nitrogen at $10^{\circ} \mathrm{C} / \mathrm{min}$ 
Appendix B

PCT Raw Data 


\section{Appendix B: PCT Raw Data}

Table B-1. PCT Raw Data for MS-LAW-1 glass

SRTC Mobile Laboratory

Customer: David Peeler

Date: 9/18/02

Samples: MS-LAW Glasses (PCT)

Units: $\mathbf{m g} / \mathbf{L}$

\begin{tabular}{|c|c|c|c|c|c|c|c|c|c|c|}
\hline & $\mathbf{A l}$ & $\mathbf{B}$ & $\mathbf{C a}$ & $\mathbf{C r}$ & $\mathbf{F e}$ & $\mathbf{L i}$ & $\mathbf{P}$ & $\mathbf{S i}$ & $\mathbf{Z r}$ & $\mathbf{N a}$ \\
\hline std & 3.88 & 19.7 & 0.082 & $<0.002$ & 3.72 & 9.81 & $<0.020$ & 48.0 & $<0.001$ & 87.4 \\
\hline BLK-1 & 0.112 & 0.027 & $<0.006$ & $<0.002$ & $<0.004$ & $<1.00$ & $<0.020$ & $<0.079$ & $<0.001$ & $<0.100$ \\
\hline BLK-2 & 0.109 & 0.237 & $<0.006$ & $<0.002$ & $<0.004$ & $<1.00$ & $<0.020$ & $<0.079$ & $<0.001$ & $<0.100$ \\
\hline arm1 & 2.93 & 13.4 & 0.049 & $<0.002$ & $<0.004$ & 7.86 & 0.479 & 36.9 & $<0.001$ & 21.8 \\
\hline arm2 & 2.64 & 13.7 & 0.064 & $<0.002$ & $<0.004$ & 7.81 & 0.292 & 36.3 & $<0.001$ & 21.9 \\
\hline arm3 & 2.40 & 12.8 & 0.070 & $<0.002$ & $<0.004$ & 7.92 & 0.232 & 36.7 & $<0.001$ & 22.5 \\
\hline MS-LAW-1, 1 & 25.8 & 0.312 & 0.049 & $<0.002$ & 0.336 & $<1.00$ & 44.1 & 18.7 & $<0.001$ & 102 \\
\hline MS-LAW-1, 2 & 25.8 & 0.245 & 0.047 & $<0.002$ & 0.293 & $<1.00$ & 44.5 & 18.5 & $<0.001$ & 99.5 \\
\hline MS-LAW-1, 3 & 26.1 & 0.294 & 0.014 & $<0.002$ & 0.239 & $<1.00$ & 45.1 & 18.8 & $<0.001$ & 104 \\
\hline MS-LAW-1CCC, 1 & 47.3 & 0.166 & 0.068 & 0.205 & 2.26 & $<1.00$ & 85.0 & 18.4 & 0.182 & 179 \\
\hline MS-LAW-1CCC, 2 & 47.3 & 0.151 & 0.057 & 0.201 & 2.50 & $<1.00$ & 85.2 & 18.2 & 0.177 & 179 \\
\hline MS-LAW-1CCC, 3 & 46.6 & 0.143 & 0.056 & 0.203 & 2.65 & $<1.00$ & 84.6 & 17.9 & 0.208 & 175 \\
\hline EA-1* & 0.205 & 40.5 & $<0.006$ & $<0.002$ & $<0.004$ & 12.1 & 0.029 & 58.8 & $<0.001$ & 103 \\
\hline EA-2* & 0.213 & 42.8 & $<0.006$ & $<0.002$ & $<0.004$ & 13.0 & 0.025 & 59.8 & $<0.001$ & 109 \\
\hline EA-3* & 0.201 & 43.0 & $<0.006$ & $<0.002$ & $<0.004$ & 12.7 & $<0.020$ & 60.0 & $<0.001$ & 107 \\
\hline std1 & 3.91 & 20.1 & 0.085 & $<0.002$ & 3.80 & 9.77 & $<0.020$ & 48.4 & $<0.001$ & 83.2 \\
\hline
\end{tabular}

* The solution was diluted 10 to 1 before submission for analysis. 


\section{Distribution}

No. of

Copies

\section{OFFSITE}

1 Catholic University of America

Vitreous State Laboratory

620 Michigan Ave., N. E.

Washington, D. C. 20064, Attn:

I. L. Pegg

8 Westinghouse Savannah River Company Aiken, SC 29808, Attn:
E. W. Holtzscheiter
773-A
C. M. Jantzen
773-A
S. L. Marra
999-W
D. K. Peeler (5)
999-W

6 University of Missouri at Rolla

Rolla, MO 65409-1170, Attn:

D. E. Day (6)
No. of

Copies

\section{ONSITE}

3 DOE/Office of River Protection

W. F. Hamel

H6-60

B. M. Mauss

H6-60

J. H. Swailes

H6-60

1 DOE/Richland Operations Office

J. A. Frey

A5-13

2 CH2M Hill Hanford Group

K. D. Boomer

L4-07

K. A. Gasper

L4-07

3 Bechtel National Inc./Washington Group

S. M. Barnes

H4-02

E. V. Morrey

$\mathrm{H} 4-02$

J. M. Perez

H4-02

23 Pacific Northwest National Laboratory

W. F. Bonner

K9-14

J. V. Crum

K6-24

P. R. Hrma

K6-24

E. O. Jones

K6-24

D-S. Kim (10)

K6-24

L. K. Holton

H6-61

M. J. Schweiger

K6-24

G. L. Smith

K6-24

H. D. Smith

K6-24

J. D. Vienna (5)

K6-24 